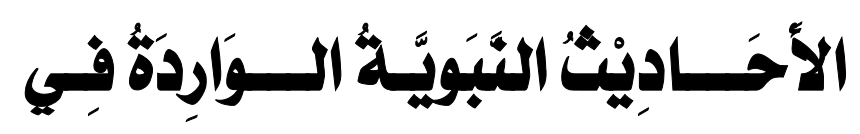

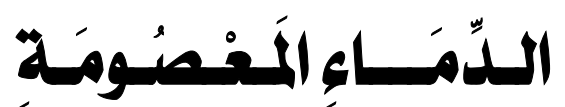

إعداد الدكتور:

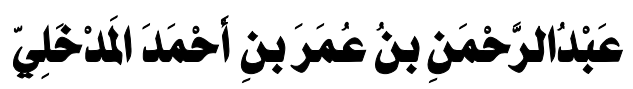

أستاذ السنة وعلومها المشارك بكلية الشريعة والقانون

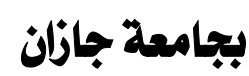

$p^{r+19}$ (ه) 


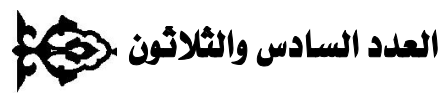

ชิ 


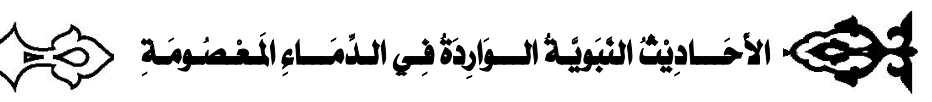
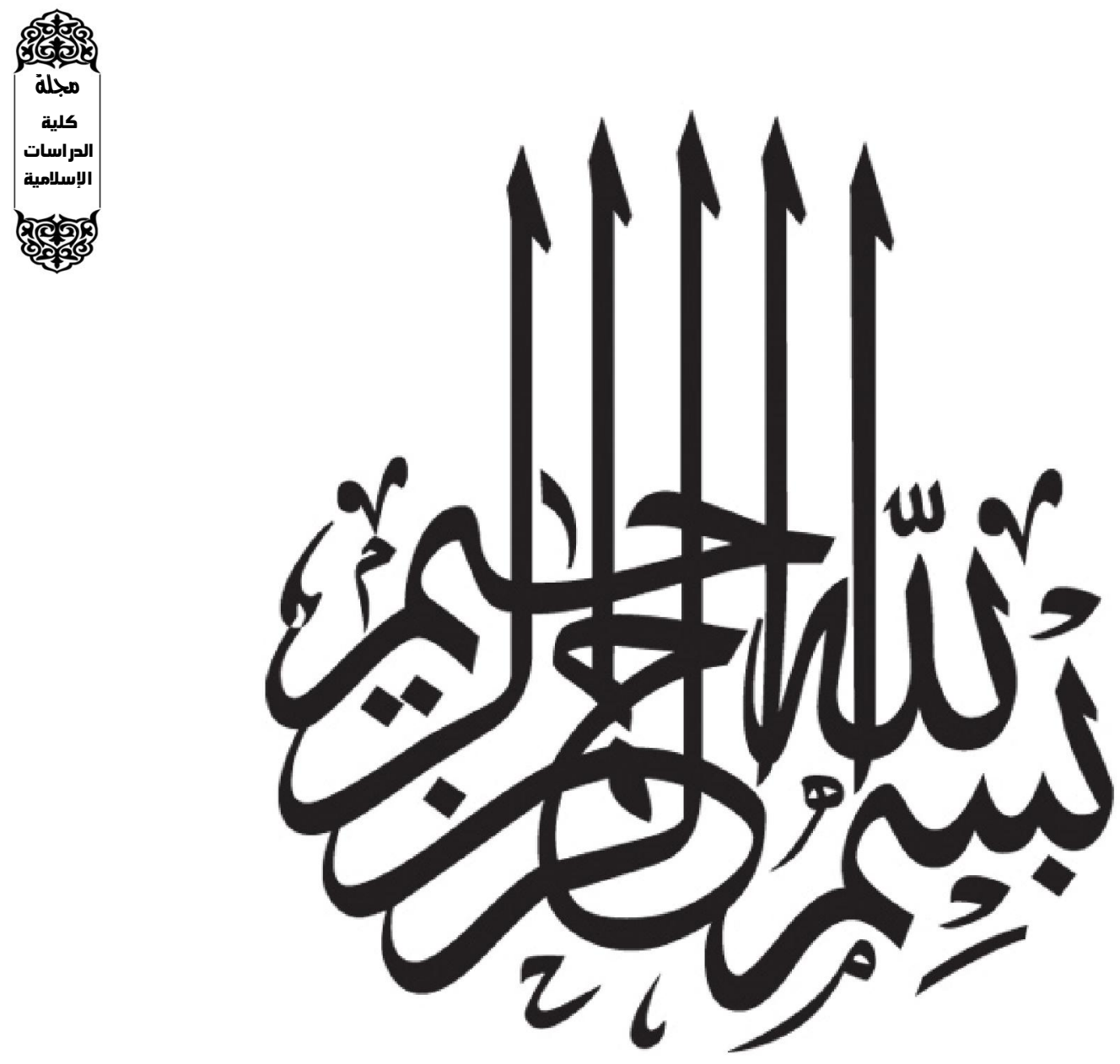

$\Lambda \mu$

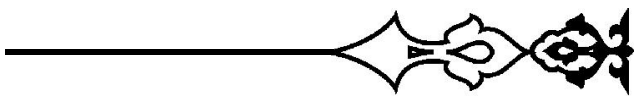




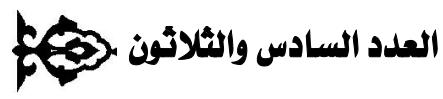

ชิ 


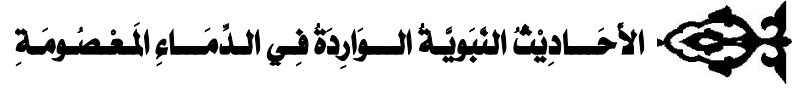

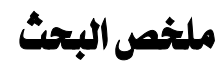

عنوان البحث: الأحاديث النبوية الواردة في الدماء المعصومة.

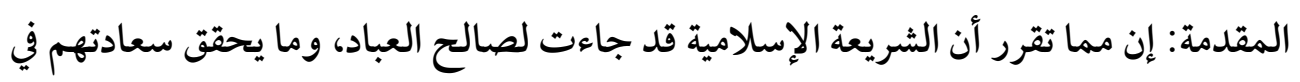

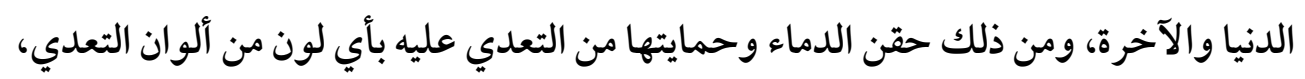

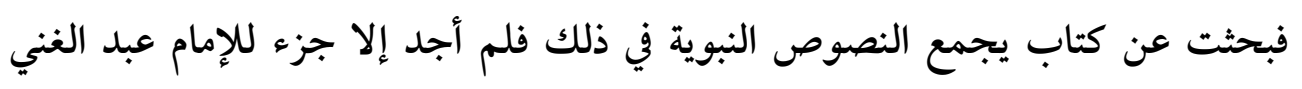

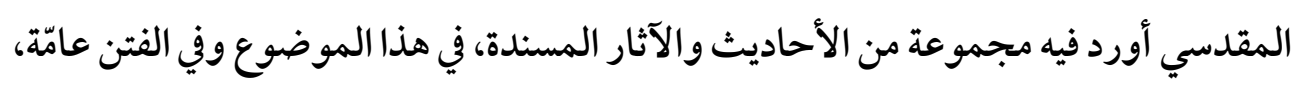
وقد حوى: الصحيح، والضعيف، والضعيف جدا، فرأيت أنّ الحاجة ماسة لجمع الأحاديث النبوية في ذلك، بطريقة علمية، فعزمت على ذلك، وقد تألف عندي منها مجموعة مبار كة، فقمت بتبويبها وتخريجها. منهج البحث: اتبعت المنهج الاستقر ائي الموصول بالتحليلي. إشكالية البحث: تكمن إشكالية البحث في الاستهانة بالدماء، سواء بين الأفراد أو الجماعات،

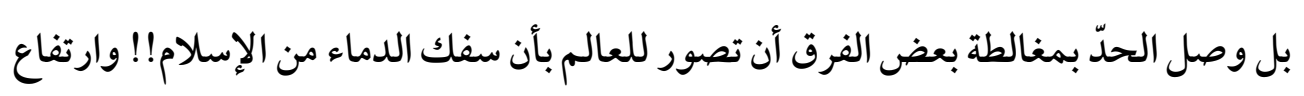

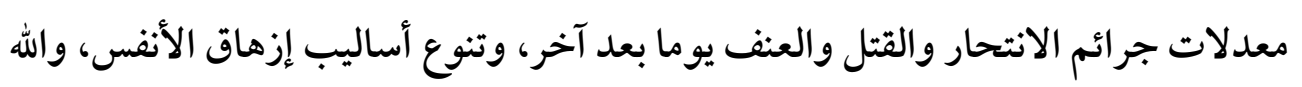

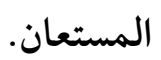

حدود البحث: حدّ هذا البحث الموضوعي هو الأحاديث الواردة في عصمة الدماء، وليس

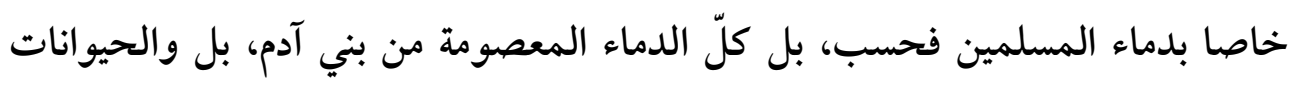
والطيور، وذكر شيء من كلام أهل العلم عليها.

الدراسات السبقة: لم أجد إلا جزء صغيرا للإمام عبد الغني المقدسي، المتوفى عام . .7هـ،

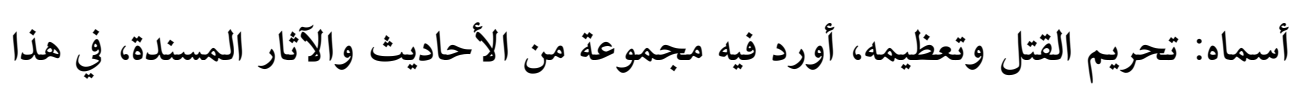

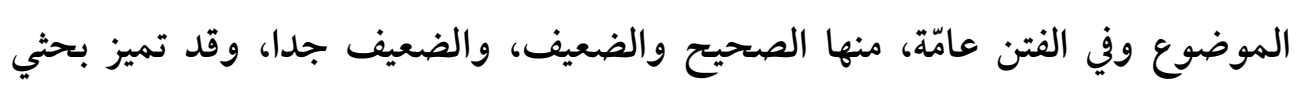

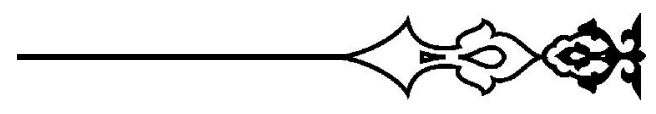




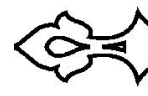

بالشمول لأحاديث عصمة الدماء، والاكتفاء بالأحاديث المقبولة فقط. أهداف البحث: يهدف هذا البحث إلى عدة أمور، أهمها: بيان صيانة الدين الحقّ للدماء وحقنه لها إلا بحقها خلافا للفرق المنحرفة الضالّة، ومحاربة سفّاكي الدماء من الأفرادوأهل البدع والأهواء من الفرق الإرهابية المنحرفة عن طريق الصواب، وإبراء الذمّة وإقامة الحجة عليهم، حيث تمسّ حاجة الثّاس في هذه العصور المتأخرة لهذا الباب من العلم، حيث اختلطت بعض مُسلَّمات الدين مع غيرها لدى من لا فقه عنده ولا علم. نتائج البحث: توصل الباحث إلى عدّة نتائج، منها: أنّ الأحاديث التي أوردتها قد بلغت حدّ لِّ التواتر المعنوي بما يفيد العلم الضروري بتشديد الإسلام في أمر الدماء، وأنّ الإسلام رتّب أشد العقويات في الدنيا والآخرة على سفك الدماء المعصومة، بل حرّم كلّ ما يؤدي لسفك الدم، بل نهى عن قتل الحيوان والطائر والحشرات بغير حقّ. توصيات البحث: من أهمها التوصية بجمع الأحاديث في هذه الأبواب التي تمسّ لها الحاجة، ونشرها لبيان حقيقة هذا الدين وسماحته ومر اعاته للإنسانية.

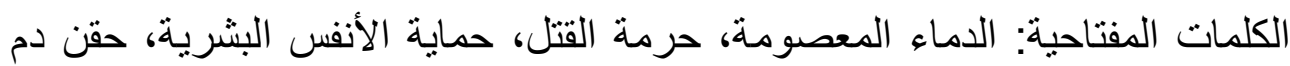
الأبرياء. والله الموفق،6،6، 


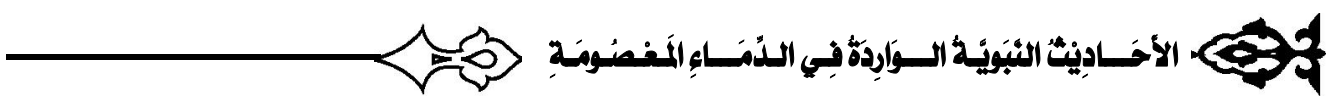 The prophetic Hadiths contained in \\ Forbidden blood \\ By: Prof. Abd al-Rahman ibn Umar ibn Ahmad al-Mudkhali \\ Associate Professor of Sunnah and Sciences, Faculty of Sharia and Law \\ At Jazan University \\ $\underline{\text { A0505769016@gmail.com }}$
}

\begin{abstract}
The Islamic Sharia seeks the well-being of human and all that achieve their happiness in this life and hereafter. The Sharia aims to save blood by all means and protect it from being shed. The researcher looked for a book that combines all the relevant Prophetic hadiths, but found nothing except for a few writings of Imam Abdul-Ghani Al-Maghdassi, that includes a number of hadiths (sayings and conduct of the prophet Muhammad) and athars (narrations by the Prophet, his Companions and Followers and also early scholars) concerning bloodshed in particular, and fitna (trial) in general. His book contains Saheh (correct), Dheef (weak) and very weak hadiths. Therefore, the researcher felt the need to combine the prophetic hadiths using a scientific method. So he decided to do so. Then he collected a number of hadiths, classified them and studied their narration.
\end{abstract}

\section{Research Methodology:}

The researcher used the inductive analytical approach.

\section{Research Problem:}

The problem of the research is about the carelessness of some individuals and groups regarding the sanctity of life. Whereas some sects think that shedding blood is a good deed in Islam. The research also sheds light on the increase in the rate of various types of suicide, killing and violence day after another. May Allah save us!

\section{Research Limitation}

This research focuses on the prophetic hadiths about the sanctity of all kinds blood, not only Muslims, but all humans as well as animals, birds. It

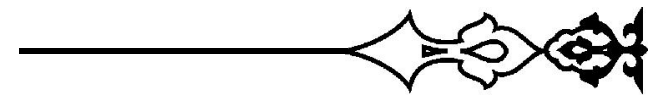




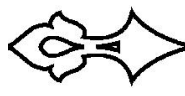

also covers some views of the scholars on that regard.

\section{Previous Studies:}

The researcher didn't find any relevant previous studies except for a few writings of Imam Abdul-Ghani Al-Maghdassi, who died in 600 A.H, entitled Prohibition and Transgression of Killing "Tahreem Alqatl Wa Tazeemuh". In this book, Al-Maghdassi has collected a number of authentic, weak and very weak hadiths and athars about this topic in particular and about fitan in general. This research is distinguished and remarkable for the comprehensive collection of only the acceptable hadiths about the sanctity of life.

\section{Research Objectives:}

This main objectives of the research are: showing the greatness of the true religion in protecting lives except for legal causes, contrary to the stray sects. It also aims to defy and provide evidence for individuals and groups of desires and innovation as well as terrorists, who involved in killing people . Today there is a compelling need for this knowledge, where some basics of the religious are mixed up and confused for those who have no or less knowledge.

\section{Results:}

The researcher finds out the following: all hadiths the researcher have provided are authentic and show clearly Islam concern about lives and the severe punishment prepared in this life and hereafter for those who kill. Islam also prohibit killing of animals, birds, and insects illegally and without cause.

\section{Recommendations:}

The researcher recommends collecting all hadiths about this topic for their importance, publish them so as to show the reality and goodness of this Religion, its eminence, and concern about humanity.

Keywords: The sanctity of life, Prohibition of killing, protection of human's life, prevention of innocent life.

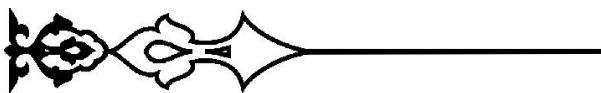



بسم الله الرحمن الرحيم

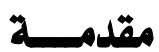

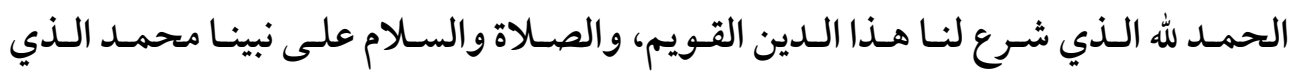
بعثـه الله رحمـة للعـالمين، فبلّنغ البلاغ المبـين، حتـى أتـاه مـن ربّهـ اليقـين، ومـا مـن خيـر

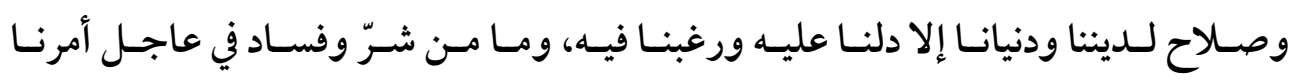

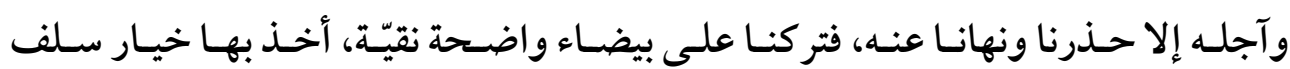

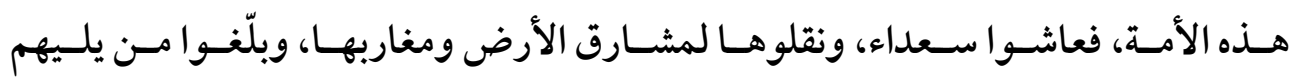
مـن عبــاد الله، حتـى خلـف مـن بعـدهم خلـوف تنكــب بعضـهم لهـذا الـدين، و أشــاحوا

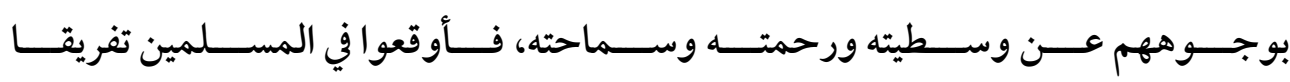

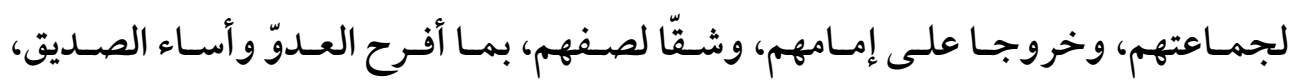
ثـم مــا لبـث هـؤ لاء الـبعض أن كفّـروا المسـلمين وحملــوا علـيهـم الســلاح، وأوقعـوا فـيهم قـتلا وإرهابـا وترويعـا، لا يرقبـون في شـيخخ ولا كهـل، ولا شـابّ ولا صـغير، ولا

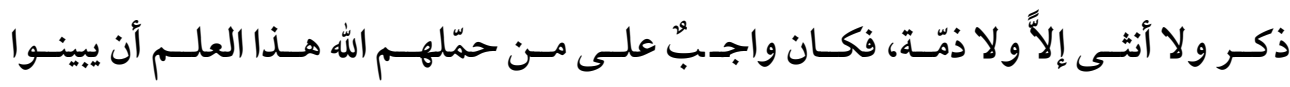

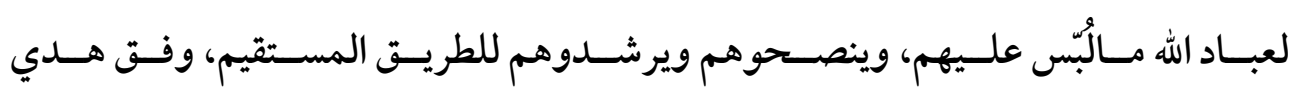
سـيّد الأولـين والآخــرين صـلى الله عليـه وسـلم، ومـن أبــخ مــا يصـلح للنصـح وبيـان

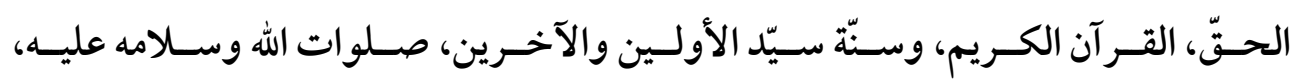

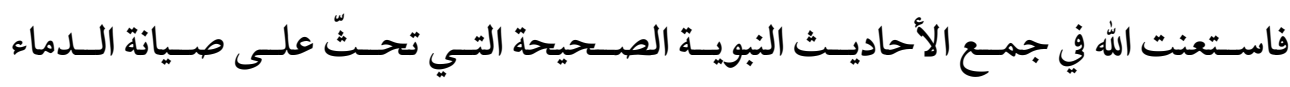

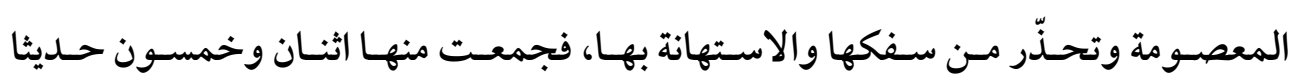
نبويا. وقد كان الباعث على جمع هذه النصوص الشرعية وإخر اجها ما يلي:

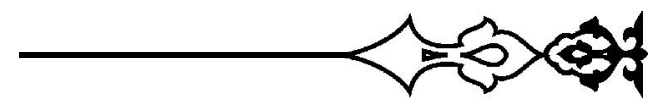




\section{ô}

سدّ ثغرة ذات أهميّة في المكتبة الإسلامية؛ حيث أنّي لم أجد كتابا أفرد ما يخصّ موضوع الدماء المعصومة من النصوص الشرعية ورتبها على هذا النسق إلا جزء لتقي الدين عبد الغني بن عبد الواحد المقدسي، المتوفى عام · ·جهـ، أسماه: تحريم القتل وتعظيمه، أورد فيه مجموعة من الأحاديث والآثار المسندة، في هذا الموضوع وفي الفتن عامّة، ومنها الصحيح والضعيف، والضعيف جدا. حاجة النّاس في هذه العصور المتأخرة لهذا الباب من العلم، حيث اختلطت بعض مُسلَّمات الدين مع غيرها لدى من لا فقه عنده ولا علم. المشار كة بالعلم الواضح والدليل القطعي في محاربة سفّاكي الدماء أهل البدع والأهواء من الفرق الإرهابية المنحرفة عن طريق الحقّ والصواب. إقامة الحجة وإبراء الذمّة على أولئك الذين استهانوا بالدماء: من الأفراد، حيث يسلّ الو احد سلاحه على الآخرين لأثفه الأسباب. نصرة الدين القويم الذي صان الدماء وحقنها إلا بحقها خلافا للفرق المنحرفة الضالّة التي سلكت طريقا وعرا من العدوانية في سفك الدماء والاستهانة بها. التوضيح لشباب المسلمين والتحصين لهم ضدّ الغاوين؛ حتى تكون حجّة الشباب مبنية على الدليل الشرعي الصحيح. ارتفاع معدلات جرائم الانتحار والقتل والعنف يوما بعد آخر، وتنوع أساليب إزهاق

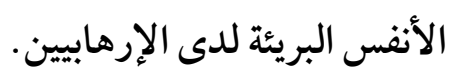
أسأل الله أن يحفظنا بحفظه، ويقينا شر أنفسنا، والحمد لله ربّ العالمين 
أقدم بين يدي هذه النصوص الشرعية بهذا التمهيد المشتمل على عدة فقرات، هي:

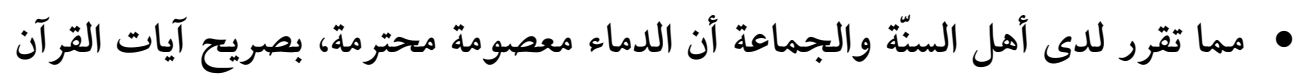

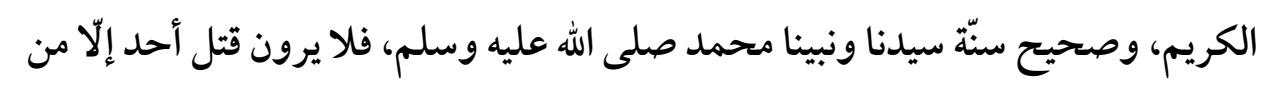

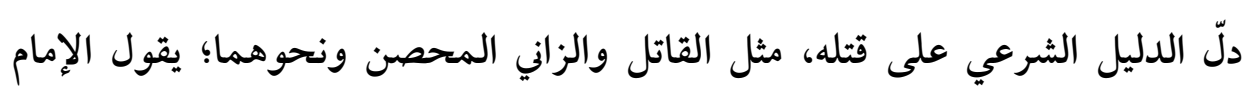

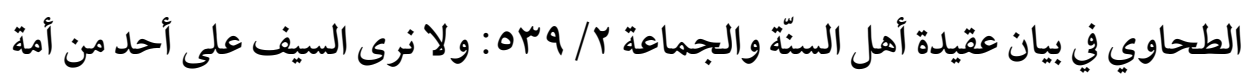

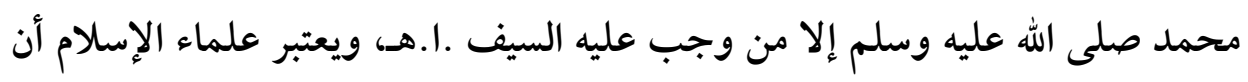

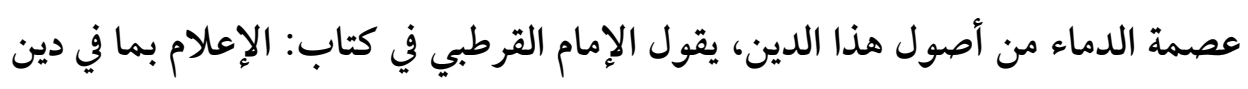

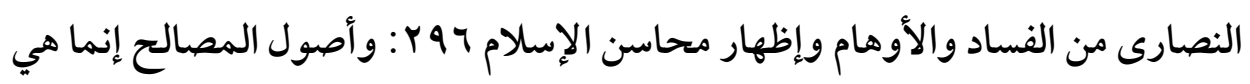

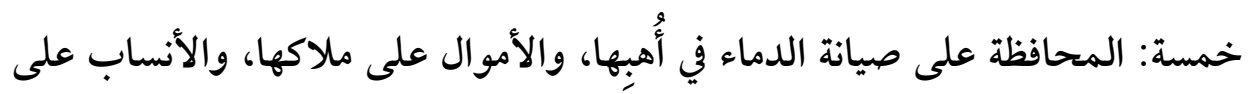
أهليها، والعقول على المتصفين بها، والأديان التي بها عيش النفوس وزكاتها لـا. هـ.

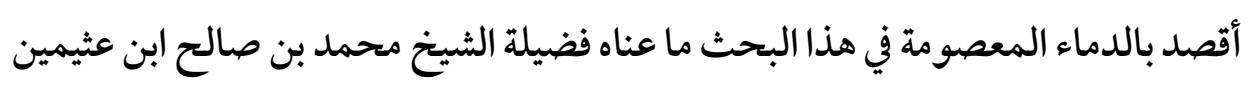

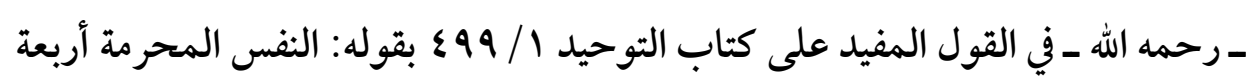
أننس، هي: نفس المؤمن، والذمي، والمعاهد، والمستأمِن؛ بكسر الميم: طالب الأمان.

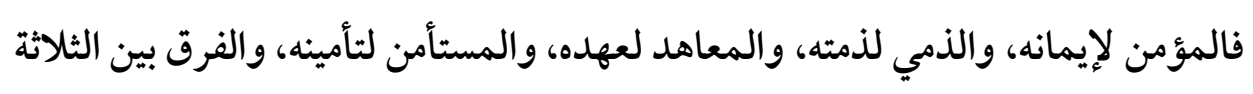

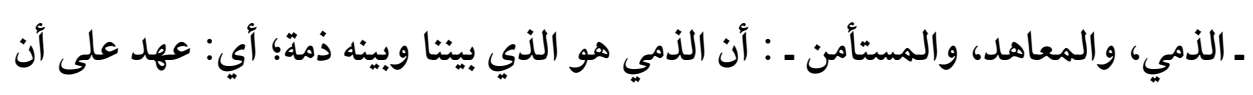

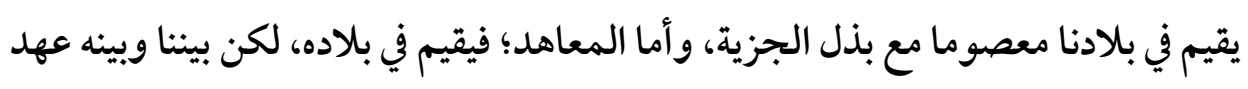

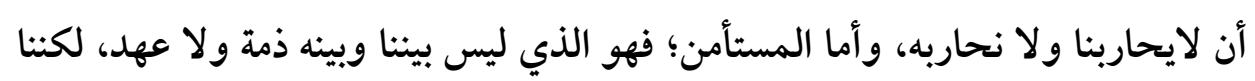

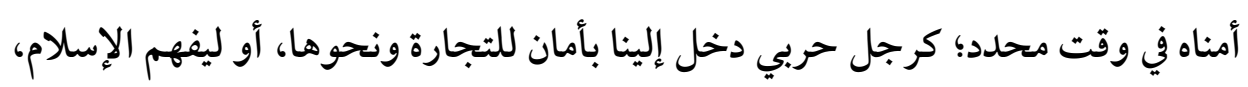

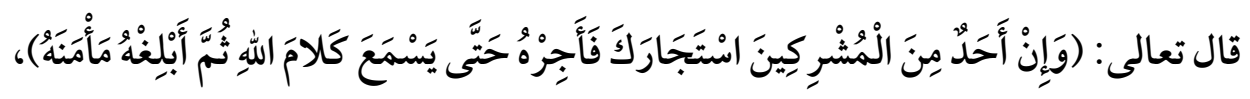
وهناك فرق آخر، وهو أن العهد يجوز من جميع الكفار، والذمة لا تجوز إلا من اليهود

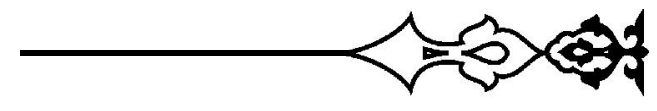




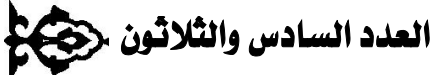

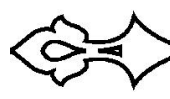

والنصارى والمجوس دون بقية الكفار، وهذا هو المشهور من المذهب، والصحيح: أنها تجوز من جميع الكفار، فهذه الأنفس الأربع قتْلها حرام، لكنها ليست على حد سواء في التحريم؛ فنفس المؤمن أعظم، ثم الذمي، ثم المعاهد، ثم المستأمن، وهل المستأمن مثل المعاهد أو أعلى؟ أشك في ذلك؛ لأن المستأمن من له عهد خاص، بخلاف المعاهدين؛ فالمعاهدون يتولى العهد أهل الحل والعقد منهم؛ فليس بيننا وبينهم عقود تأمينات خاصة، وأيا كان؛ فالحديث عام، و كل منهم معصوم الدم والمال.أ.هـ. هلزم على جميع أهل الإسلام الإذعان لما في الكتاب والسنّة من الهُدى والبيان، وعدم

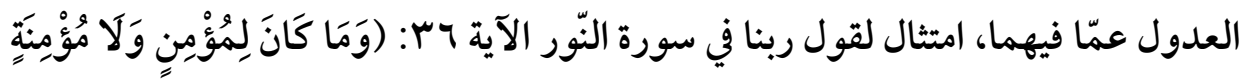

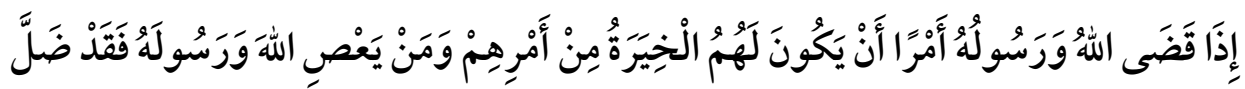

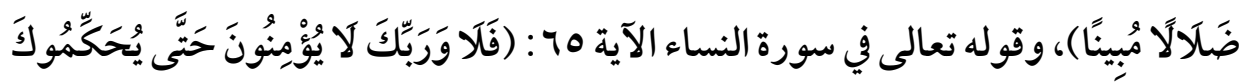

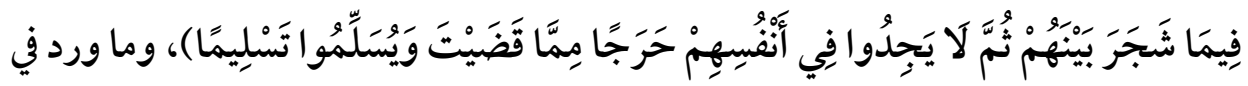

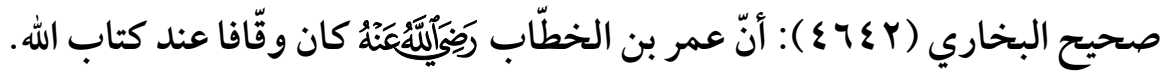
• من مقاصد جمع هذه الأحاديث تشجيع الشباب على حفظها واستظهارها المؤدي - بإذن الله ـ للعمل بها وتبليغها ونشرها بين الناس، وليكون ذلك عاصما ـ بإذن الله ـ عن الوقوع في المحذور.

اشتملت هذه الصفحات على بضع آيات قرآنية من كلام الله العزيز الحميد، عزوتها لأماكنها، واثنين وخمسين حديثا نبويا، وفيها قدسية. • جميع ما في هذه المجموعة من الأحاديث النبوية من المحتجّ به، فجُّلّها صحيح، وقليل منها حسن، ونزهتها عن الضعيف والمنكر والموضوع، وما كان منها من حديث في الصحيحين أو أحدهما فإنّي أقتصر في العزو إليهما فقط، نظرا لجلالتهما، ولا أضيف إليهما غيرهما إلا لزيادة لفظة أو فائدة لا توجد في لفظهما، وأمّا ما كان من الأحاديث في

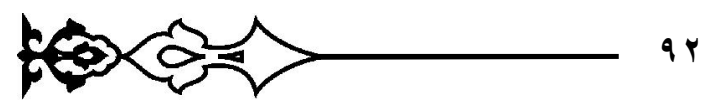


غير الصحيحين فإنّي أنقل حكم المحدِّثين عليه، من المتقدمين والمتأخرين، بعبارة

$$
\text { مختصرة. }
$$

• سلكت في التخريج العزو المختصر، برقم الحديث غالبا، ولم أتوسع أو أستوعب؛ إلا إذا دعت الحاجة. • لم أترجم للصحابة ـ رضوان الله عليهم ـرواة هذه الأحاديث لشهرتهم، ولتوفر الكتب التي ترجمت لهم. تخيرت مجوعة مفيدة من روائع كلام أهل العلم الراسخين فيه، من الأئمة القدماء والمعاصرين، من نفائس كلامهم، وجميل عبار اتهم، بما يُجلّي اللفظ النبويّ ويزينه، مما يُفرح به، ولا يُستغنى عنه، انتخبتها بعد طول نظر ومراجعة، وشرحت الغريب، وبيّنت الأماكن، ولم أتوسع في شرح الأحاديث وتحليلها ونحو ذلك: من التعريفات، والتعليقات. • بلغ عدد الصحابة الذين رووا هذه الأحاديث ـ التي أوردتها في هذه الصفحات ـ عن النبي ـ صلى الله عليه وسلم ـ واحد وعشرون صحابيا، منهم: أبوبكر الصديق خليفة رسول الله صلى الله عليه وسلم، وفيهم اثنان من العشرة المبشرين بالجنّة، وهم أبو بكر، والزبير بن

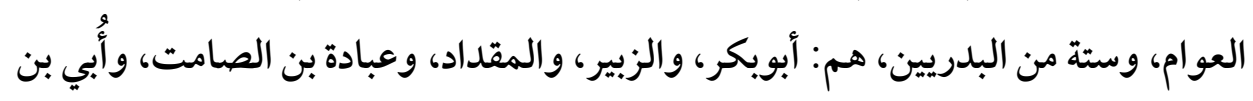
كعب، وابن مسعود، ومنهم من السابقين الأولين للإسلام، ومنهم من هاجر الهجرتين، ومنهم من المكثرين في رواية الحديث ومن المقلّين، ومنهم متقدمي الوفاة ومتأخريها، رضي الله عنهم جميعا وبلغهم من الجنة الفردوس الأعلى؛ ومثل هذا الجمّ من خيار الصحابة وساداتهم إذا رووا أحاديث في موضوع واحد لا يشكّ المحدث في الحكم منم بالتواتر المعنوي على تلك الأحاديث بعد استكمالها لشروط الحديث المتواتر، كما هو هنا، وعلماء الحديث يحكمون بالتواتر إذا ورد في الباب خمسون حديثا، قال الإمام

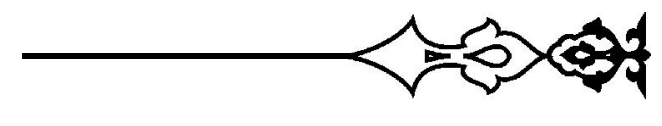




\section{العدد السادس والثلاثون . 20)}

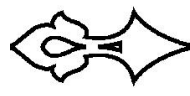

الشو كاني في كتابه التوضيح: والأحاديث الواردة في المهدي التي أمكن الوقوف عليها منها خمسون حديثًا فيها الصحيح والحسن والضعيف والمنجبر وهي متواترة بلا شك ولا شبهة بل يصدق وصف التواتر على ما هو دونها على جميع الاصطلاحات المحررة في الأصول.ا.هـ. من كتاب الإذاعة لما كان ويكون بين يدى الساعة لصديق حسن خان با | | ، وعلى ذلك فإنّه يحصل العلم اليقيني الجازم الذي لاشك فيه ولامرية بحر مة الدماء المعصومة، يقول الحافظ ابن حجر في نزهة النظر ؟؟ : المعتمد أن الخبر المتواتر يفيد العلم الضروري وهو الذي يضطر إليه الإنسان بحيث لا يمكن دفعه.ا.هـ. مع أنّ هناك أحاديث أخرى عن عدد من الصحابة لم تشملها هذه الصفحات في هذا الموضوع وردت ضمنا.

وضعت بعض العناوين اليسيرة للأحاديث لتسهيل الرجوع إليها وتصنيفها. مجموع هذه الأحاديث اثنان وخمسون حديثا، وقد صنّف العلماء كتبا تحت مسمى (خمسون حديثا) في أبواب متفرقة من العلم، منهم: المحدث أحمد بن المحب المقدسي

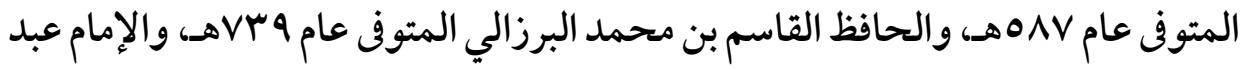
الرحمن بن أحمد بن رجب الحنبلي المتوفى عام 9 \هـ، الذي أكمل الأربعين النووية، وغيرهم رحمهم الله تعالى، أمّا جمع أحاديث موضوع واحد بدون تقيّد بعدد فالكتب في ذلك أكثر من أن تُحصر.

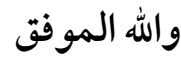



بِسْمِ اللَّهِ الرَّحْمَنْ الرَّبحِيم

\section{تحريم القتل}

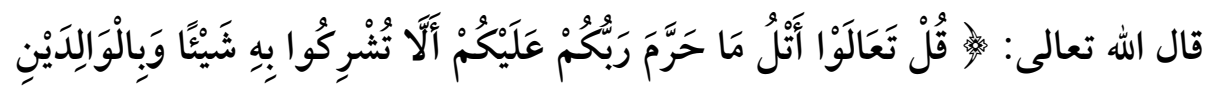

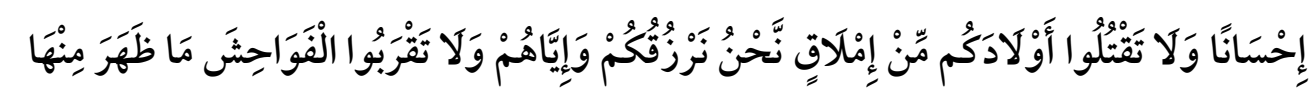

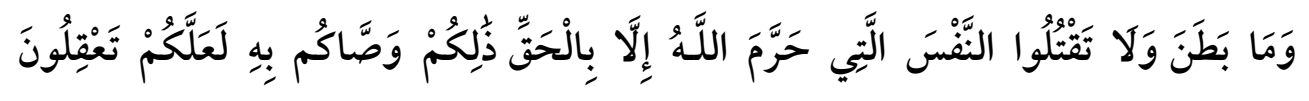
(r)(1) 101

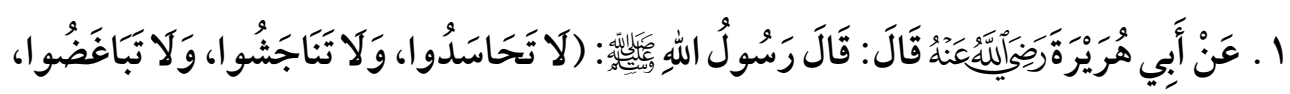

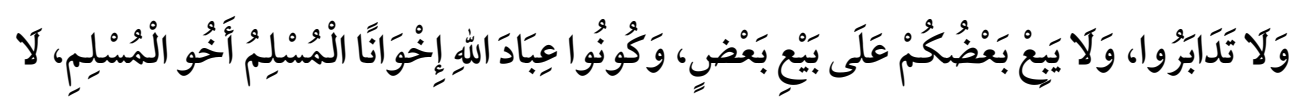

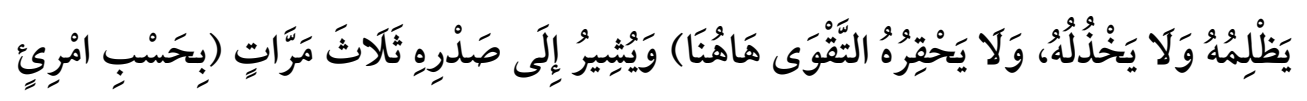

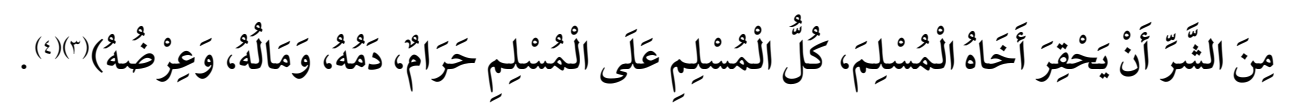

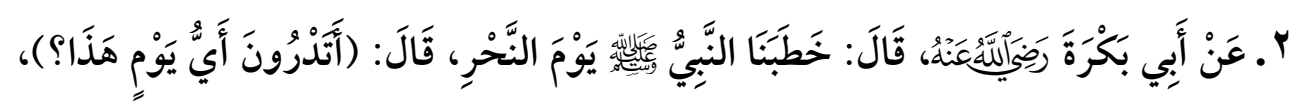

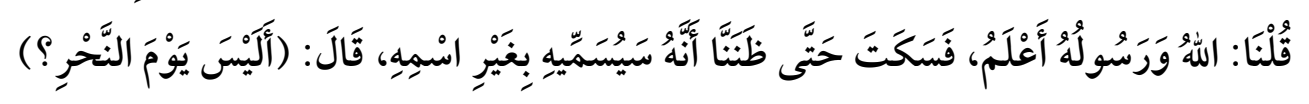

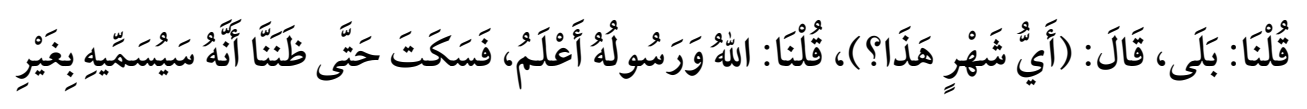

(1) (1) (1) سورة الأنعام.

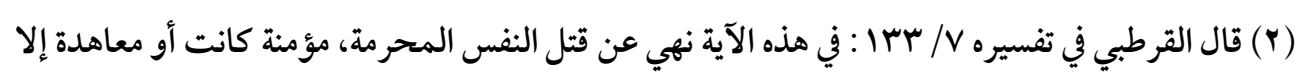

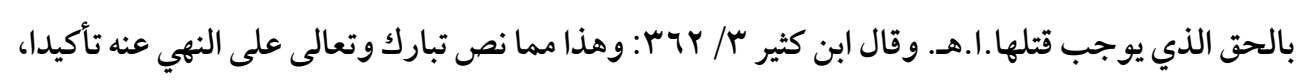
وإلا فهو داخل في النهي عن الفواحش ما ظهر منها وما بطن.

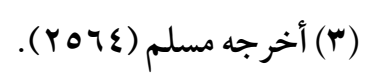

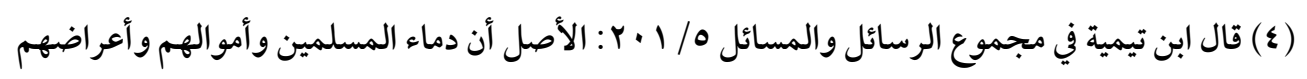
محرمة من بعضهم على بعض لا تحل إلا بإذن الله ورسوله. 


\section{क人}

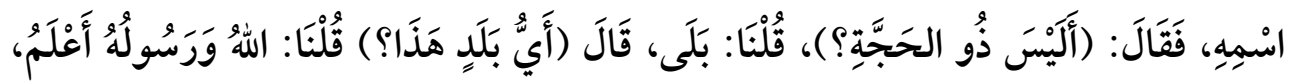

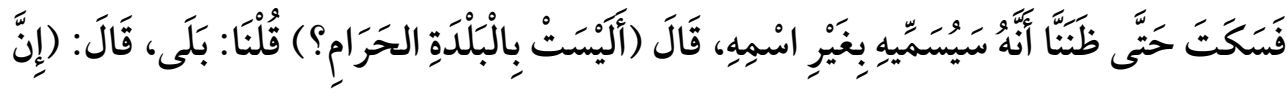

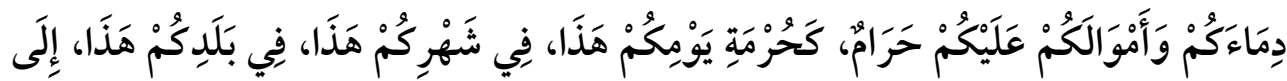

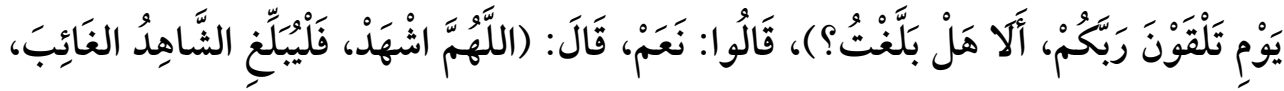

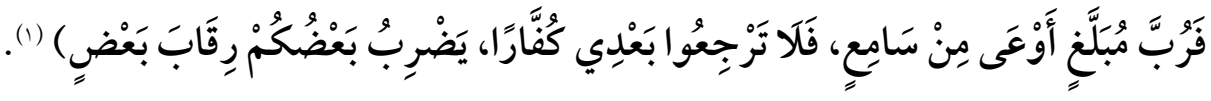
تعظيم إثم أولّل من سنَّ القتل

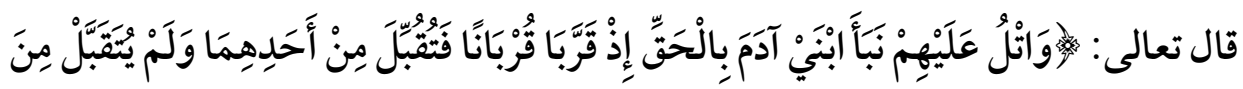

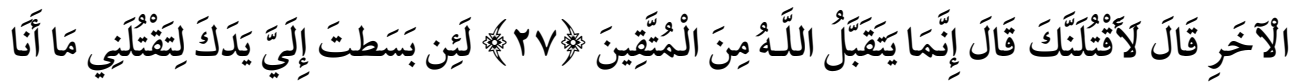

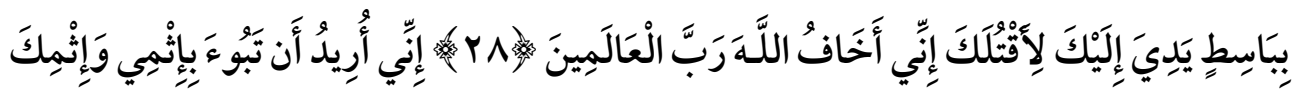

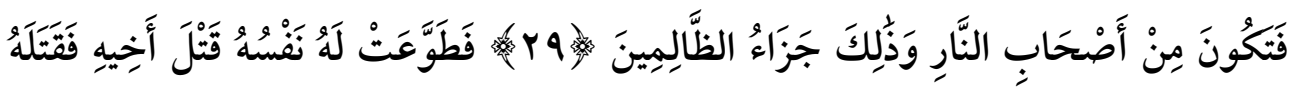

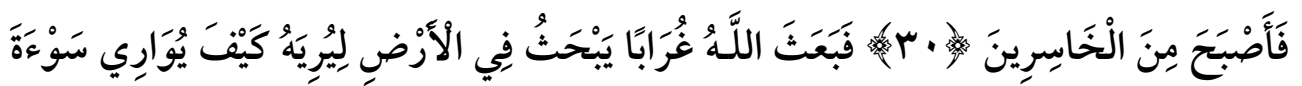

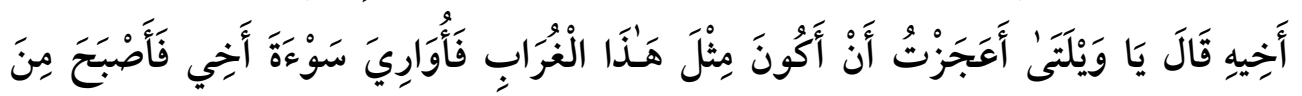

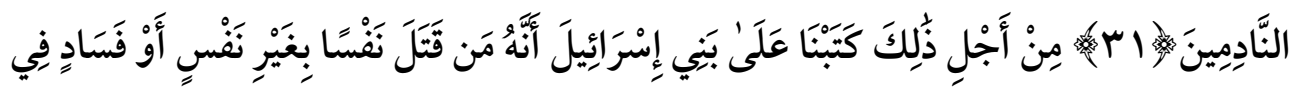

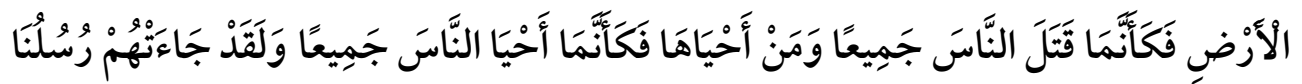

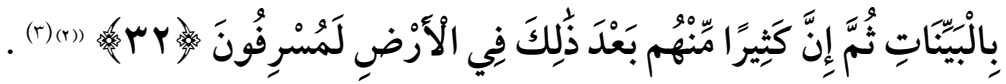

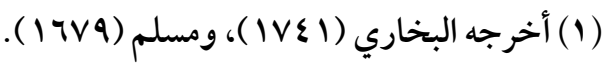
(ץ) سورة المائدة.

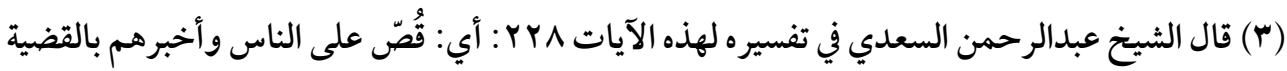

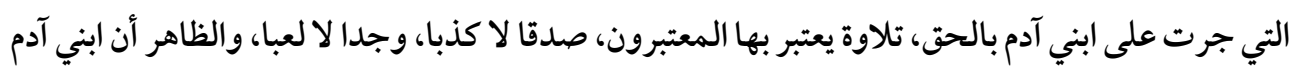
هما ابناه لصُلْبه، كما يدل عليه ظاهر الآية والسياق، وهو قول جمهور المفسرين، أي: اتل عليهم نبأهما في

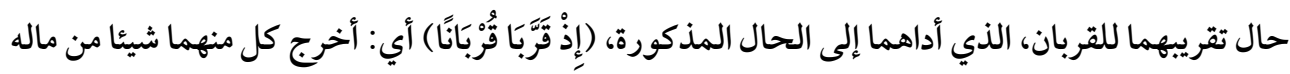




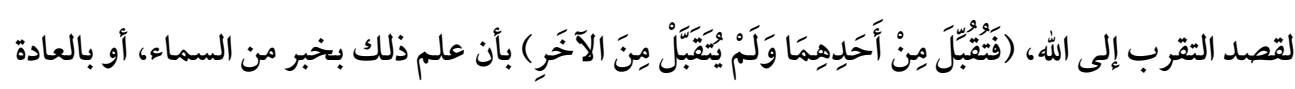

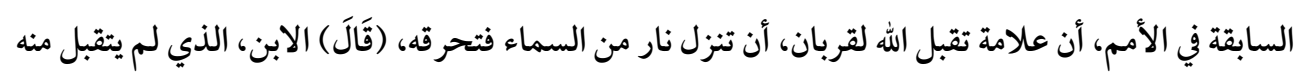

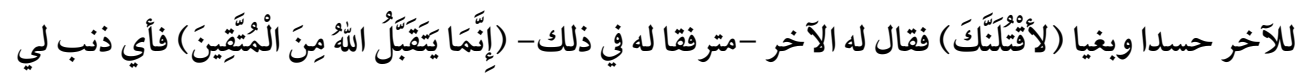
وجناية توجب لك أن تقتلني؟ إلا أني اتقيت الله تعالى، الذي تقواه واجبة عليّ وعليك، وعلى كل أحدى، وأصح

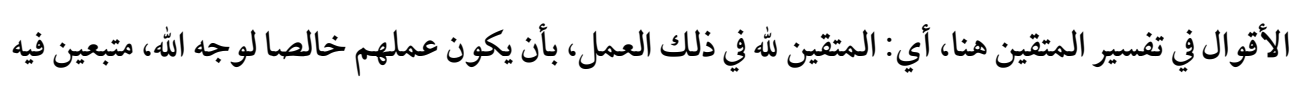

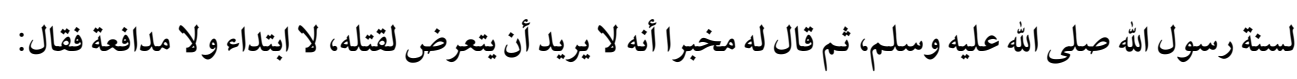

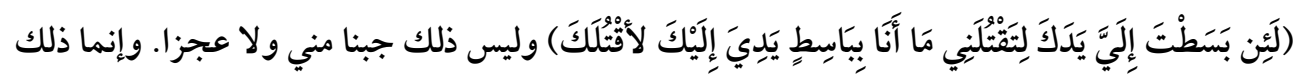

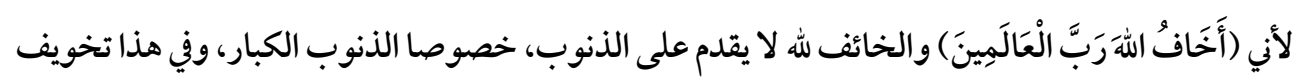

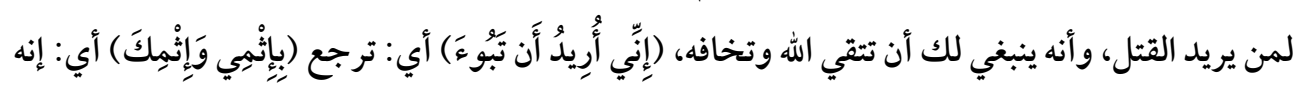

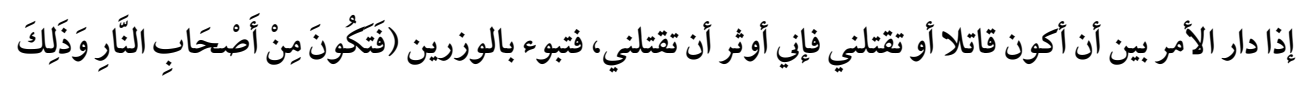

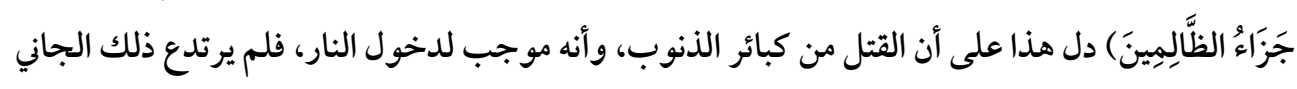

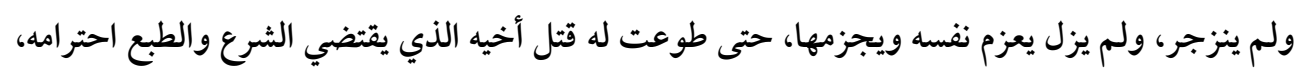

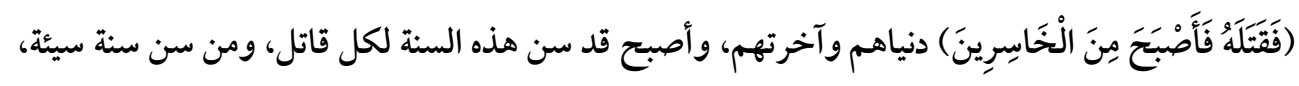

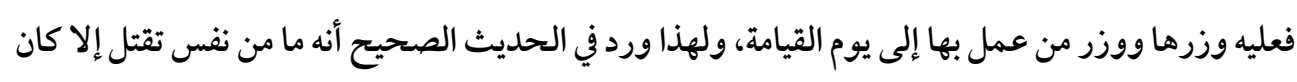

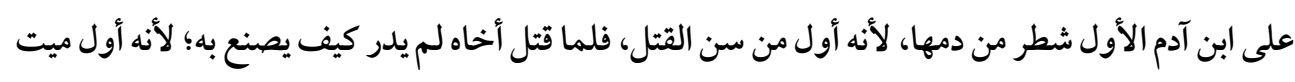

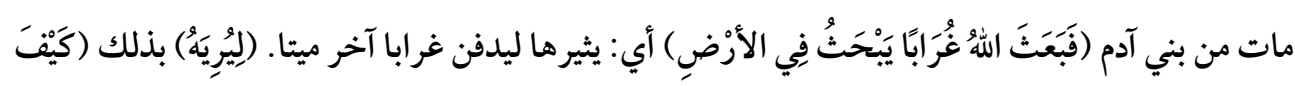

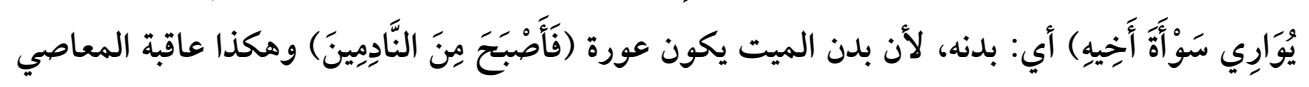

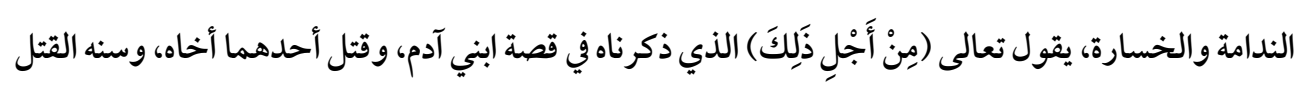

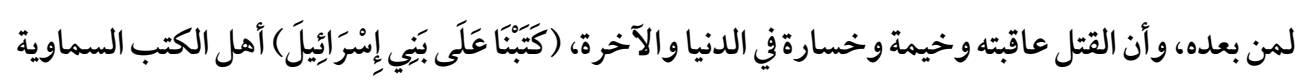

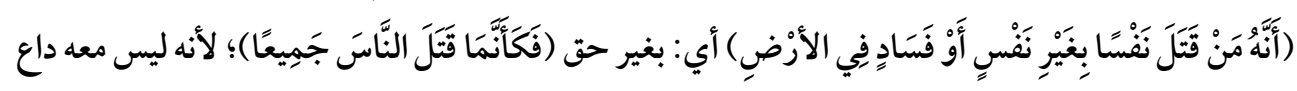

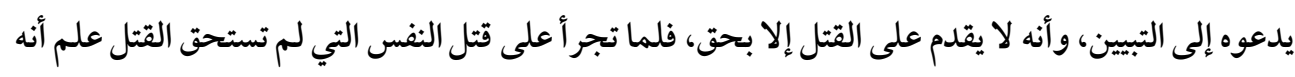

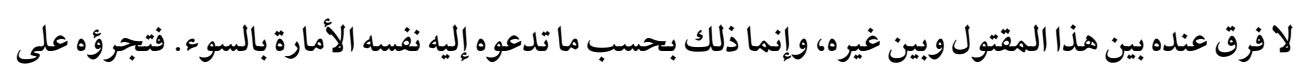
قتله، كأنه قتل الناس جميعا، وكذلك من أحيا نفسا أي: استبقى أحدا، فلم يقتله مع دعاء نفسه له إلى قتله،

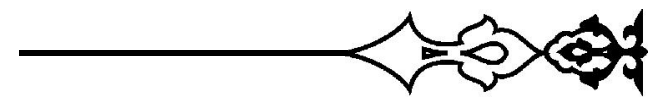




\section{舟}

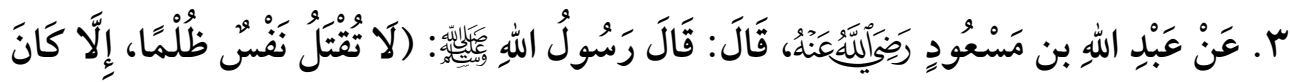

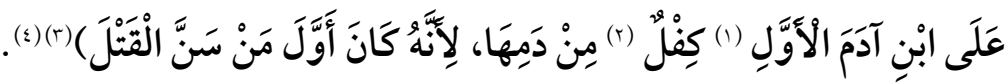

\section{القتل من أكبر الكبائر}

قال تعالى :

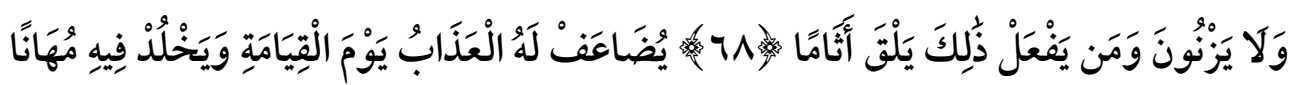

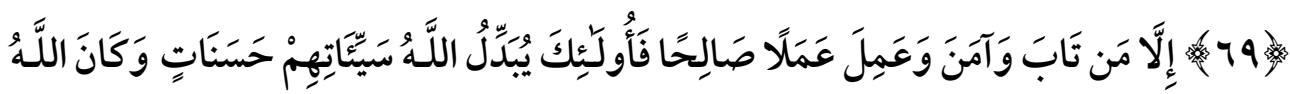
غَغْورًا رََّحِيمًا

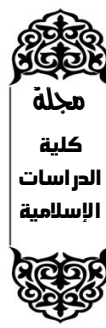

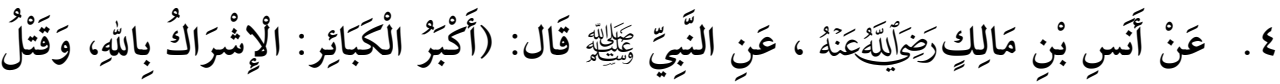

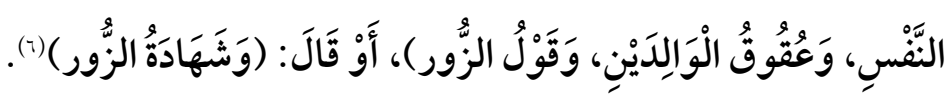

فمنعه خوف الله تعالى من قتله، فهذا كأنه أحيا الناس جميعا، لأن ما معه من الخوف يمنعه من قتل من لا

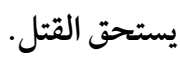
(1) قال ابن حجر في فتح الباري / / ه هץ: هو قابيل بن آدم في قتله لأخيه هابيل.

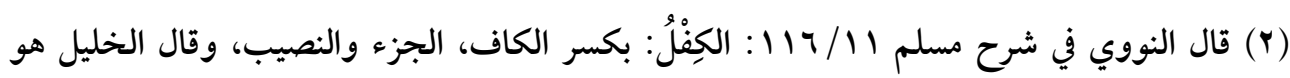
الضِّعْف.

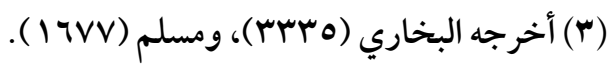

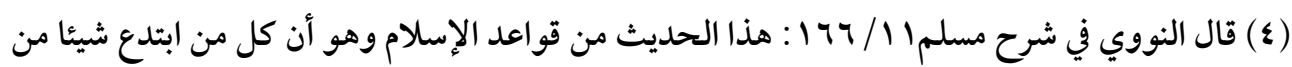
الشر كان عليه مثل وزر كل من اقتدى به في ذلك العمل مثل عمله إلى يوم القيامة، ومثله من ابتدع شيئا من الخير كان له مثل أجر كل من يعمل به إلى يوم القيامة، وهو موافق للحديث الصحيح من سن سنة حسنة،

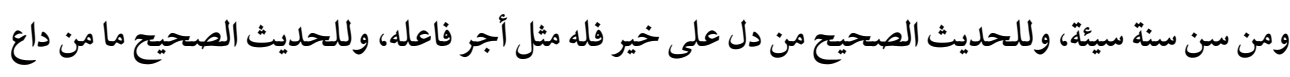
يدعو إلى هدى، وما من داع يدعو إلى ضلالة، والله أعلم.

$$
\text { (૪) (૪ورة الفرقان. }
$$




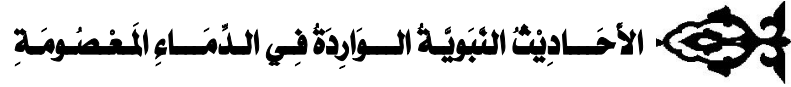

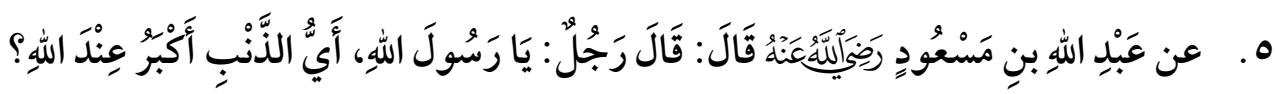

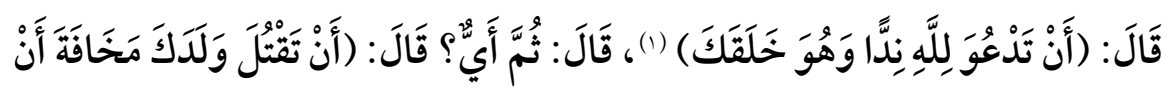

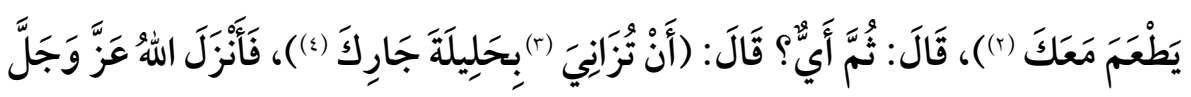

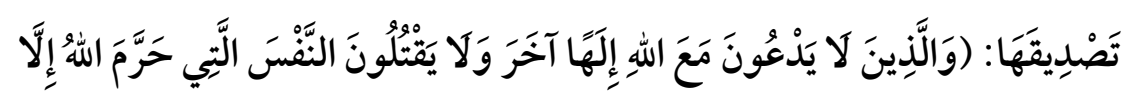

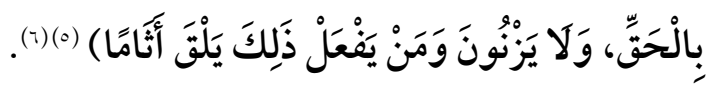

(1) قال ابن تيمية في مجموع الفتاوى / / / : اعلم رحمك الله أن الشرك بالله أعظم ذنب عصي الله به. ثم

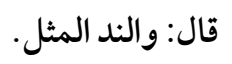

(Y) قال ابن حجر في الفتح Y / 1 / : قوله: (أن تقتل ولدك) قال الكرماني: لا مفهوم له، لأن القتل مطلقا

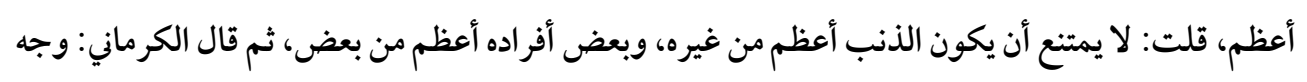
كونه أعظم أنه جمع مع القتل ضعف الاعتقاد في أن الله هو الرزاق.

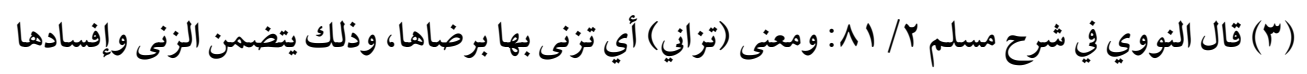

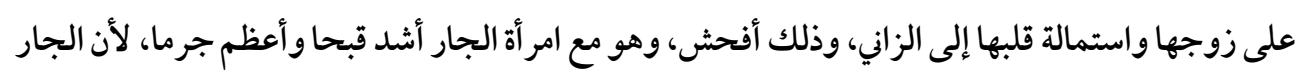
يتوقع من جاره الذبّ عنه وعن حريمه ويأمن بوائقه ويطمئن إليه، وقد أمر بإكر امه والإحسان إليه، فاذا قابل

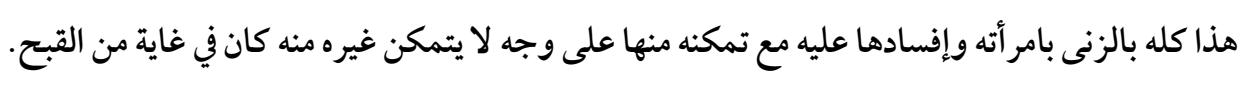

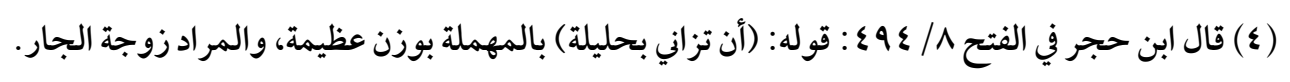

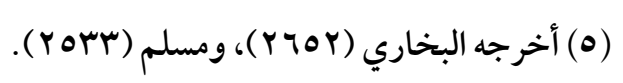

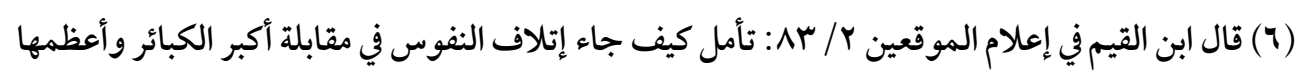

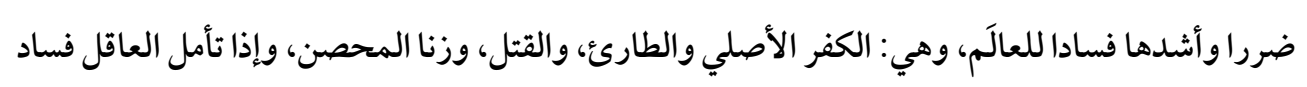
الوجود رآه من هذه الجهات الثلاث، وهذه هي الثلاث التي أجاب النبي صلى الله عليه وسلم لعبد الله بن

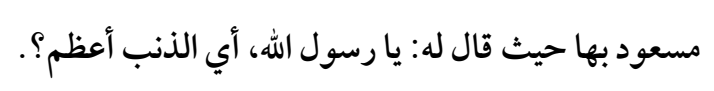

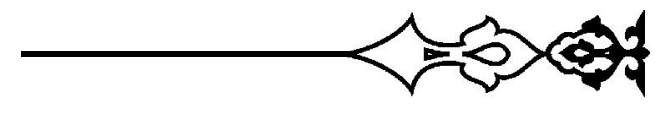




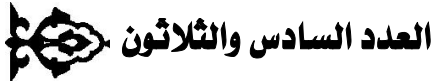

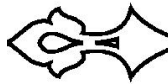

\section{توعد قاتل المؤمن بعدم المغفرة وعدم قبول العمل ووقوعه في الهلاك}

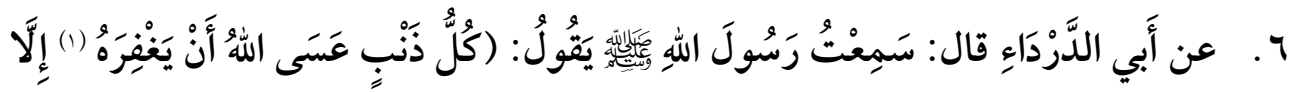

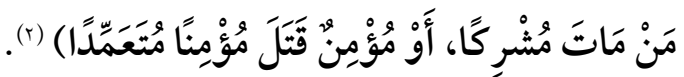

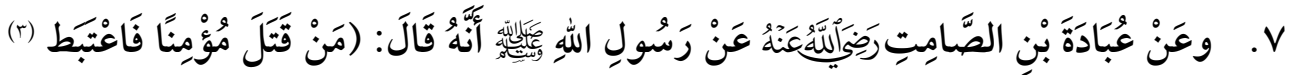

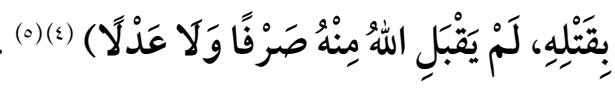

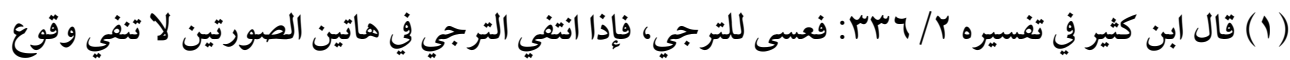

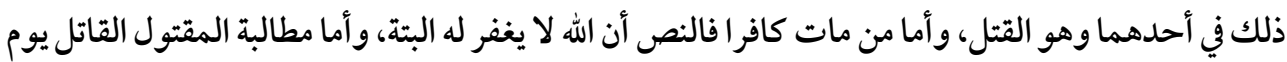
القيامة فإنه حق من حقوق الآدميين، وهي لا تسقط بالتوبة، ولكن لا بد من ردها إليهم ولا فرق بين المثتول والمسروق منه والمغصوب منه والمقذوف وسائر حقوق الآدميين، فإن الإجماع منعقد على أنها لا تسقط بالتوبة، ولكنه لا بد من ردها إليهم في صحة التوية، فإن تعذر ذلك فلا بد من المطالبة يوم القيامة، لكن لا يلزم

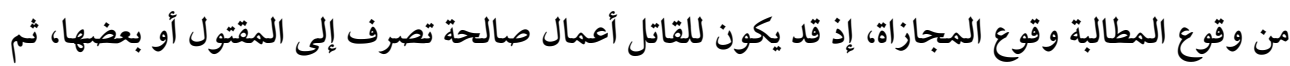
يفضل له أجر يدخل به الجنة أو يعوض الله المقتول بما يشاء من فضله من قصور الجنة ونعيمها، ورفع درجته فيها، ونحو ذلك، والله أعلم.

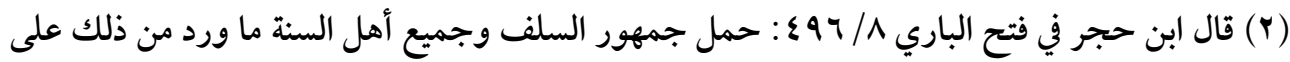
التغليظ، وصححوا توبة القاتل كغيره.

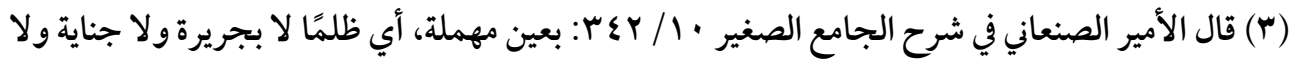
قصاص، من عبطت الناقة نحرتها من غير داء بها، وقيل: إنه بالمعجمة من الغبطة والسرور، وقد قال الإمام

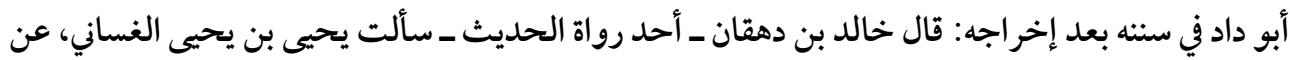

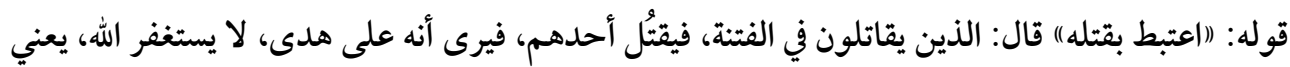
من ذلك.

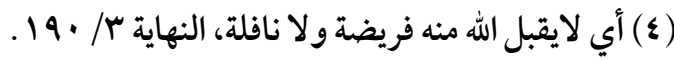

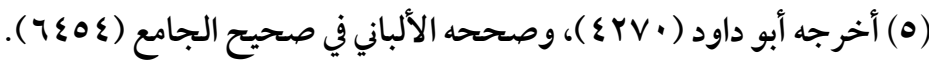

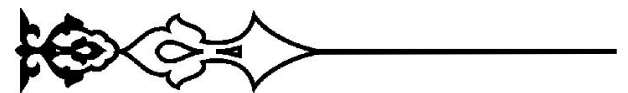




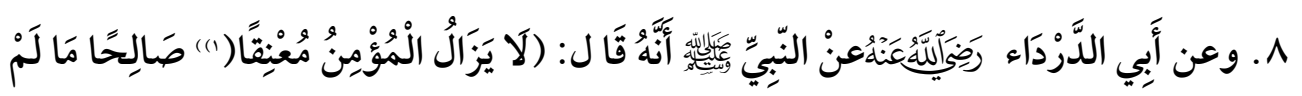

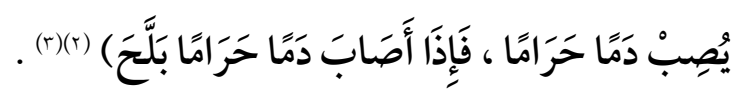

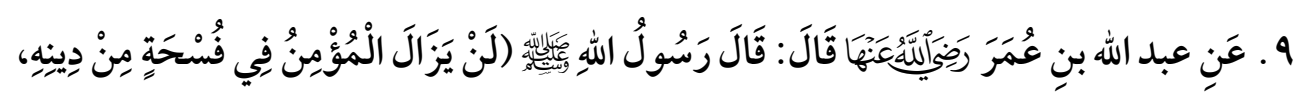

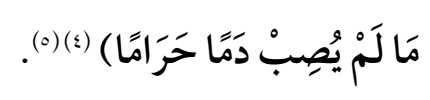

\section{نفس المؤمن أعظم حرمة عند الله من الكعبة المعظّمة}

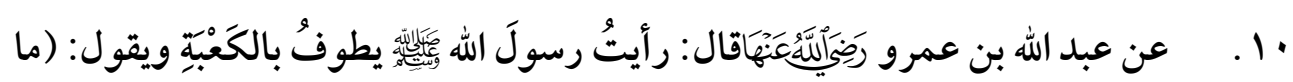

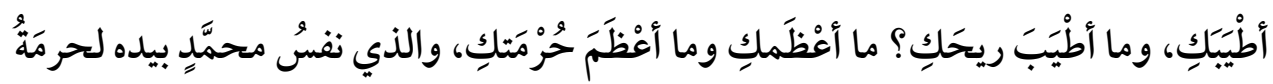

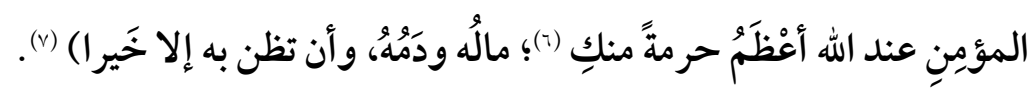
من أبغضِ الناس إلى الله من أصرّ على عزمه قتل امرئ بغير حق

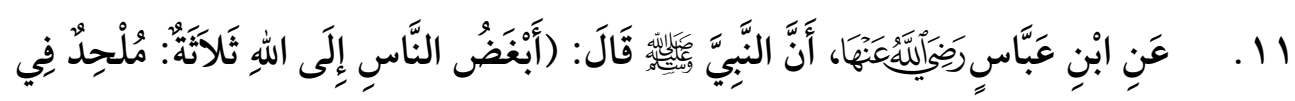
(1) أي مسرعا في طاعة الله منبسط في عمله، وانظر النهاية م/ • آس .

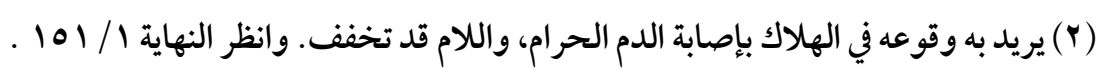

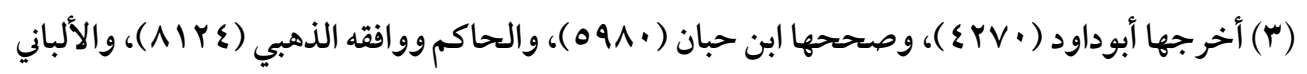
في السلسلة الصحيحة (11) (11).

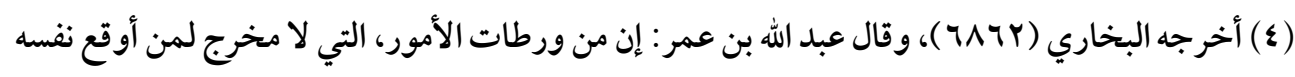

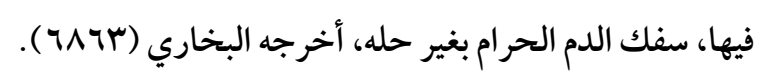

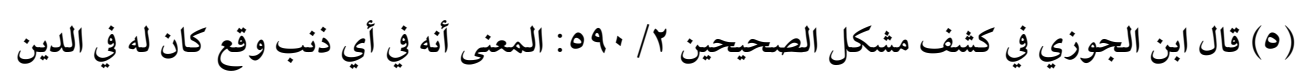
والشرع مخرج إلا القتل، فإن أمره صعب.

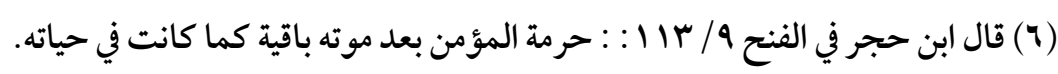

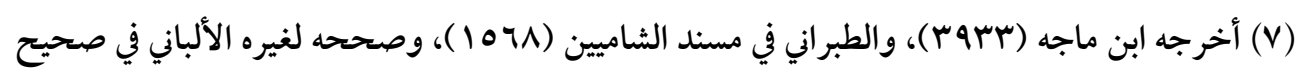

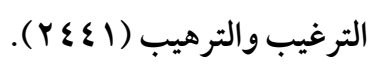




\section{赵}

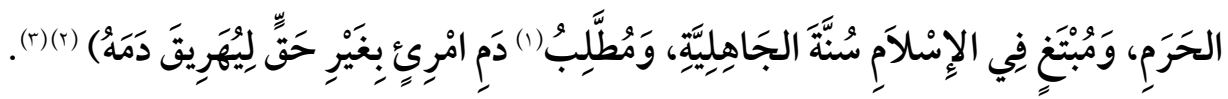

\section{القتل من إضلال عدونا الشيطان، ومن أحبّ الأعمال إليه}

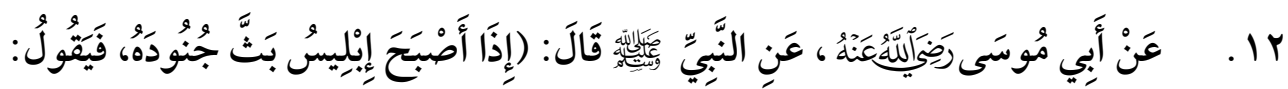

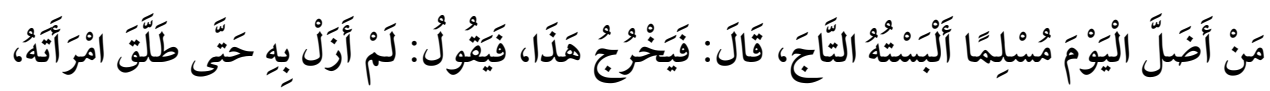

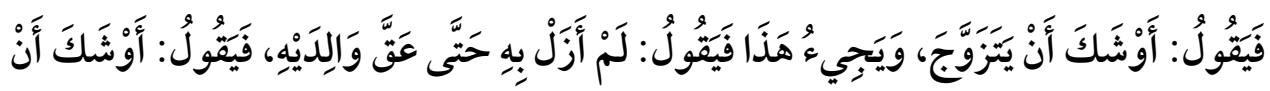

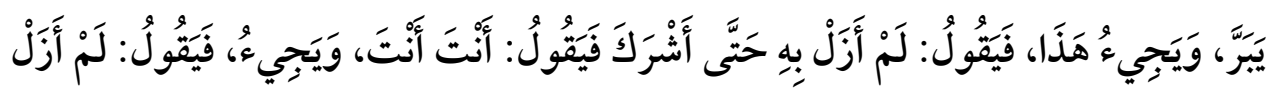

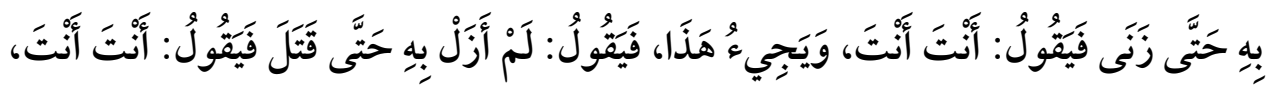

(1) قوله: (ومُطَّبَب) بالتشديد، مفتعل من الطلب فأبدلت التاء طاء وأدغمت، والمراد من يبالغ في الطلب،

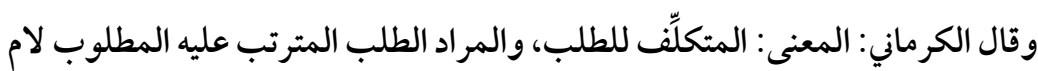
جرد الطلب، أو ذكر الطلب ليلزم الزجر في الفعل بطريق الأولى، وقوله: (ليهريق) بفتح الهاء ويجوز

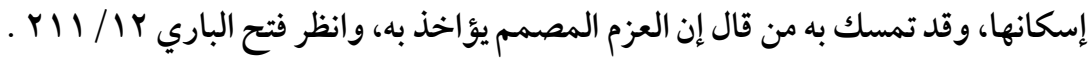

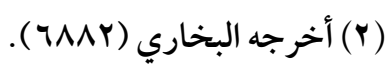

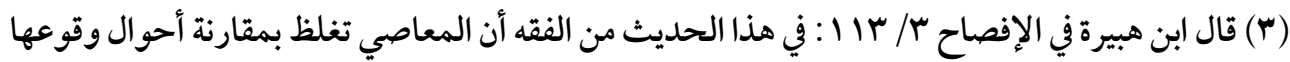

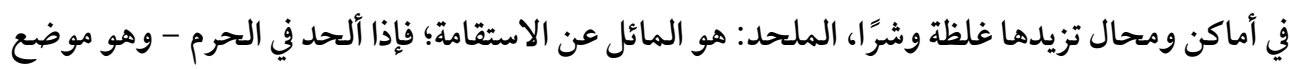
يقصده أهل الميل ليستقيموا فيه - فمال هو عن الحق في ذلك الموضع الذي يقوم لله فيه قاصد به - اشتد غضب الله عليه، قوله: (ومبتغ في الإسلام سنة جاهلية) والسنة الجاهلية: مهجورة متروكة بما جاء الله به من الإسلام ومحاسنه، فإذا أراد الإنسان استبدال الحسن من سنن الإسلام بالقبيح من سنن الجاهلية أبغضه الله عز وجل، وقوله: (ومطلب دم امرئ) المطلب: الطالب، والدم لو وجب لإنسان طلبه بحق لكان من شأن الإن الإنسان

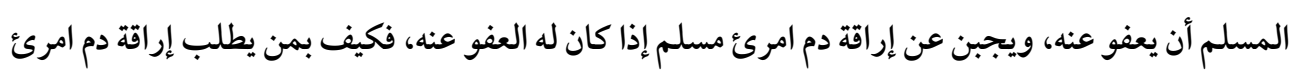




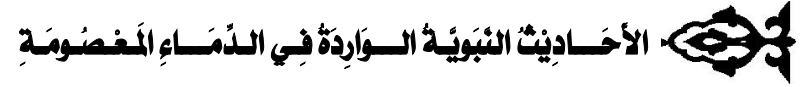

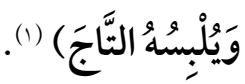

\section{قتال المسلم كثر}

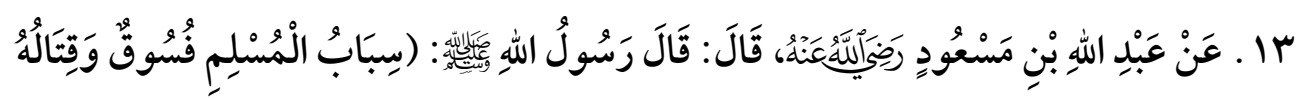
كُفر (r) (r) (r) (

\section{نفي الإيمان عن القاتل}

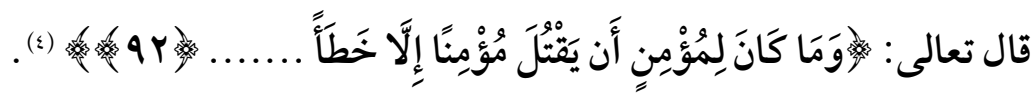

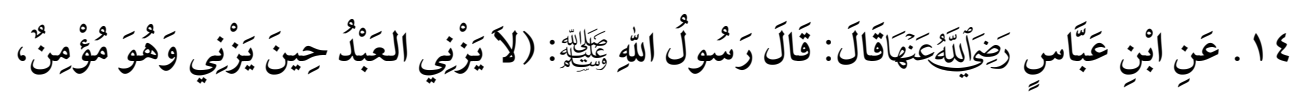

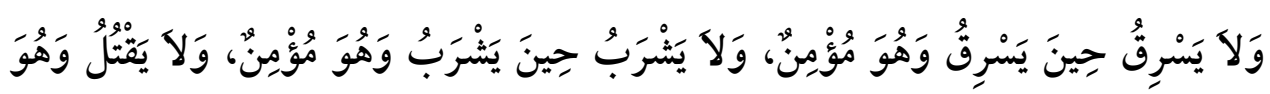

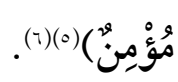

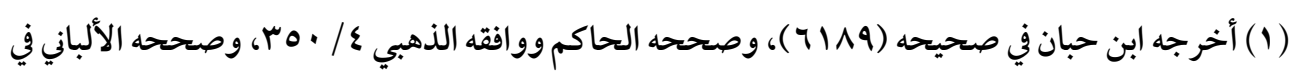

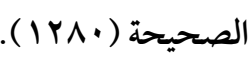

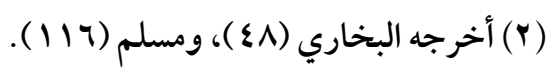

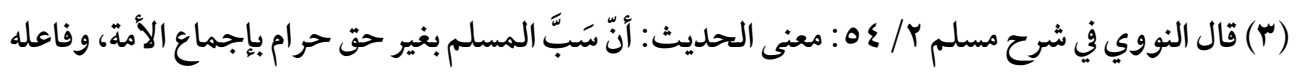

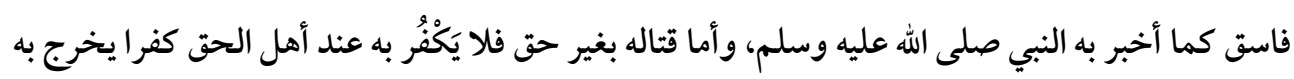

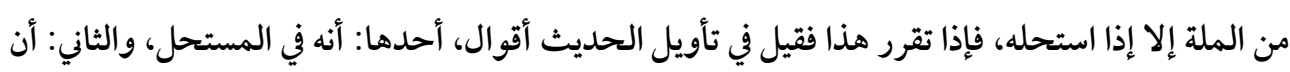

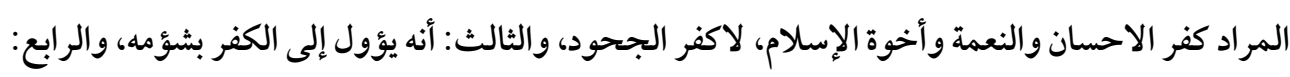
أنه كفعل الكفار، والله أعلم. ا.هـ. بتصرف يسير.

$$
\begin{aligned}
& \text { ( ) سورة النساء. } \\
& \text { (ه) أخرجه البخاري (9 • (1) ). }
\end{aligned}
$$

(ج) قال الشيخ حافظ الحكمي في أعلام السنّة المنشورة 99 : الكفر العملي الذي لا يخرج من الملة، هو : كل

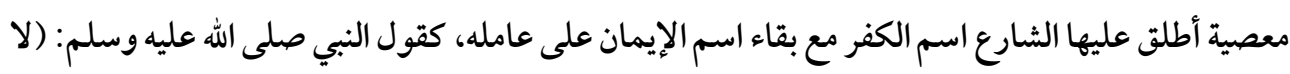

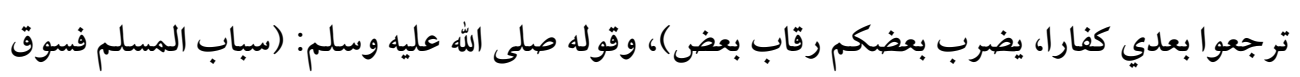


العدد السادس والثلاثثرن هي

\section{زوال الدنيا أهون على الله من قتل مسلم}

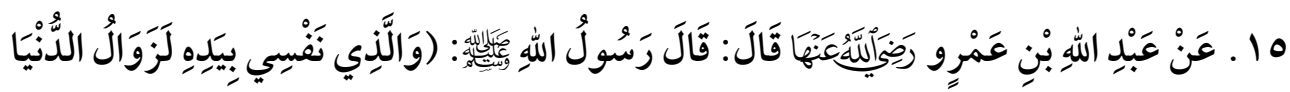

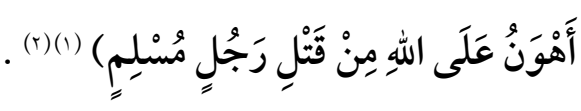

وقتاله كفر)، فأطلق صلى الهُ عليه وسلم على قتال المسلمين بعضهم بعضا أنه كفر، وسمى من يفعل ذلك

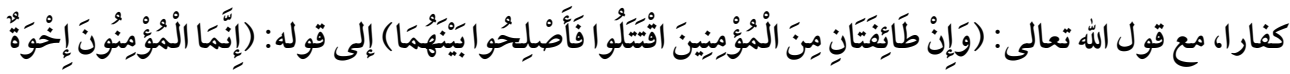

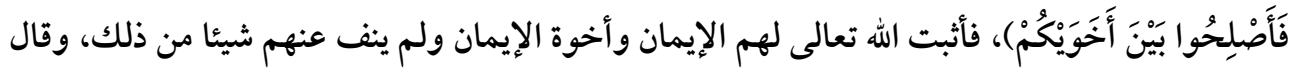

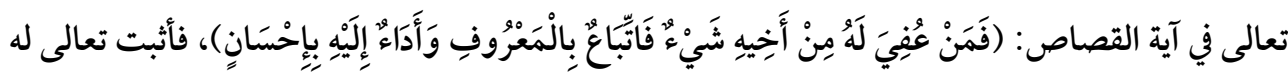

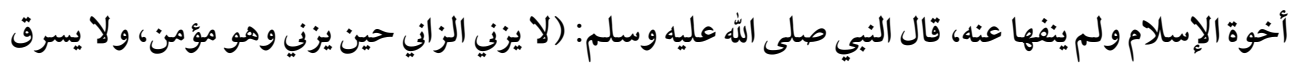

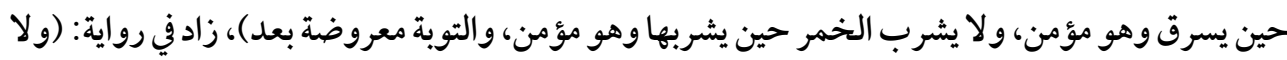

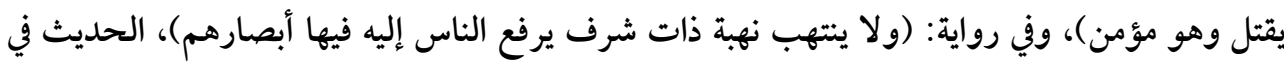

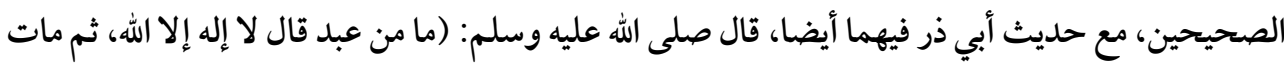

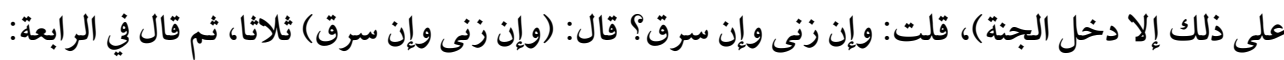

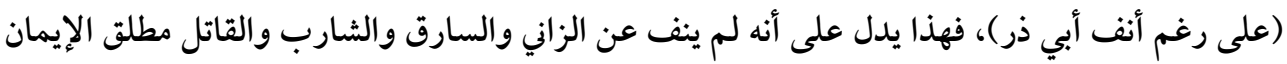

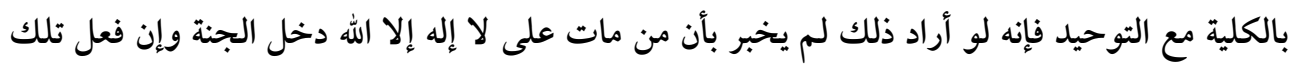

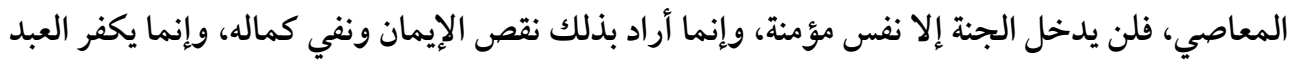

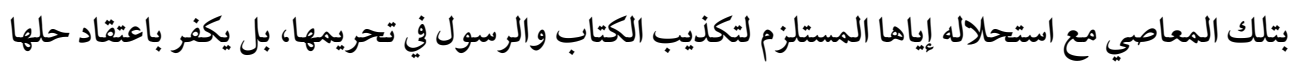
وإن لم يفعلها، والله سبحانه وتعالى أعلم.

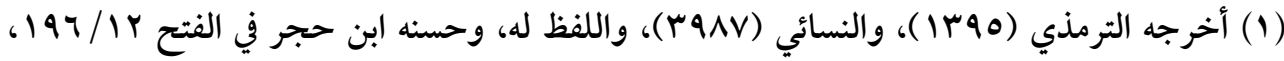

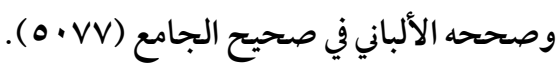

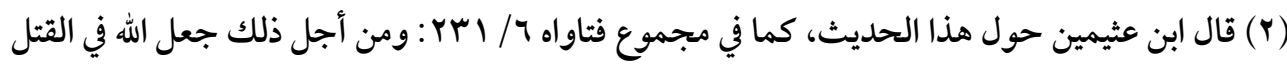
المتعمد عقوبات غليظة وقصاصا ثابتا.

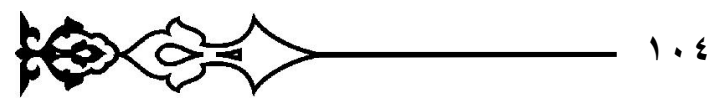




\section{3

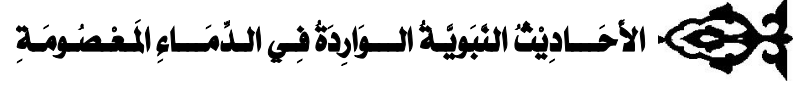

التحديزُمن حمل السلاح على المسلمين، وفي أماكن تجمعاتهم، واجتنابُ ترويعهم به حتى

\section{ولو كان مزحا}

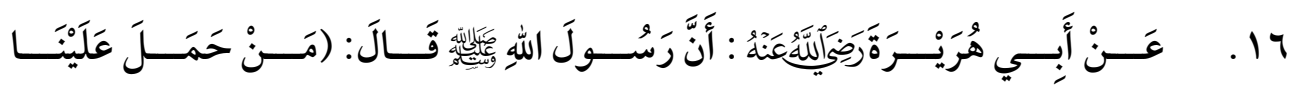

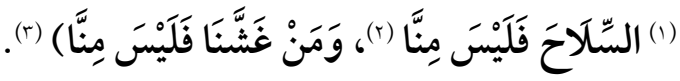

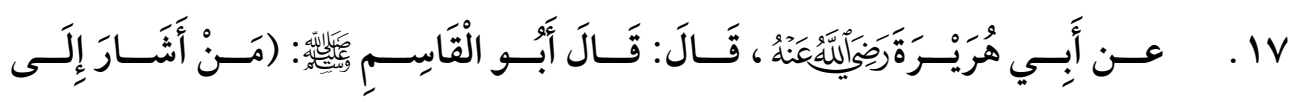

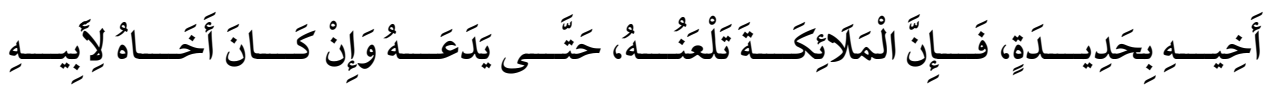

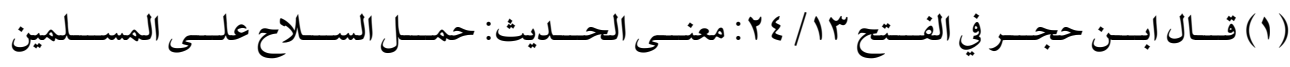

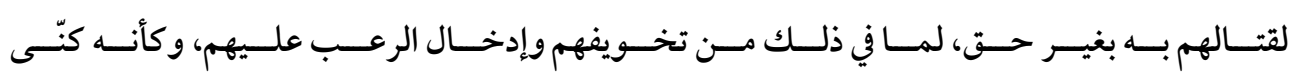

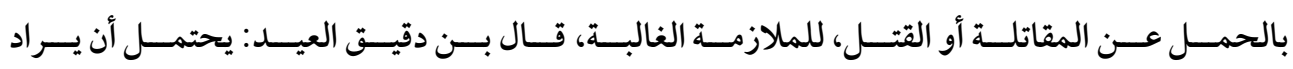

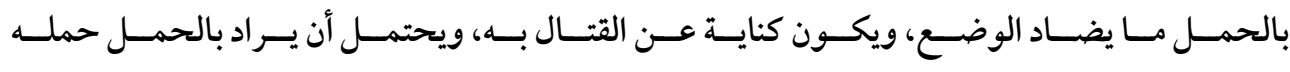

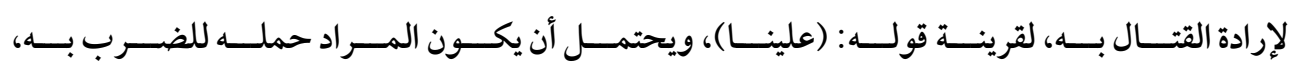
وعلى كل حال ففيه دلالة على تحريم قتال المسلمين والثشديد فيه.

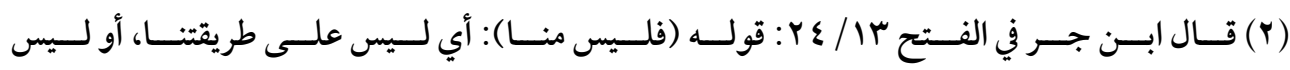

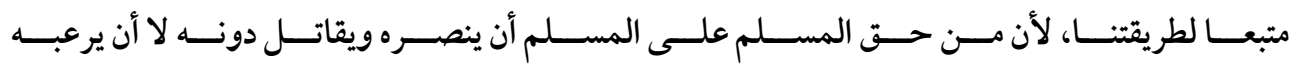

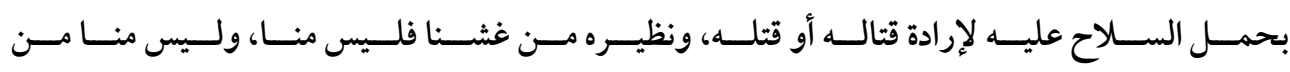

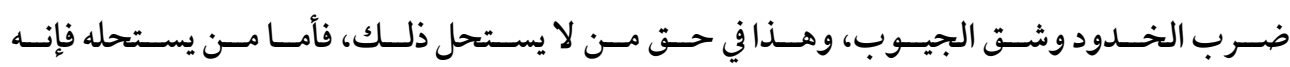

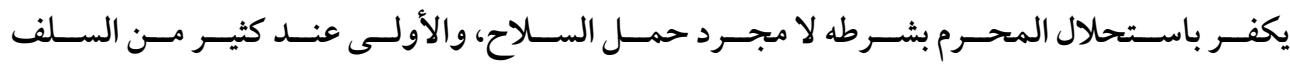

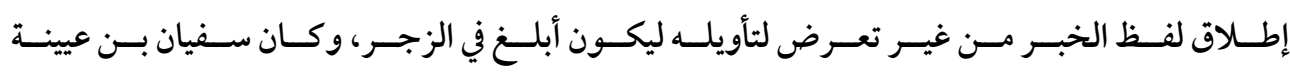

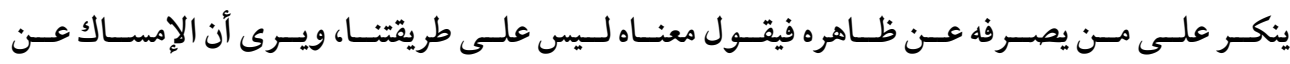

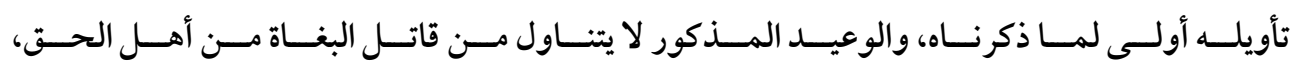
فيحمل على البغاة وعلى من بدأ بالقتال ظالما.

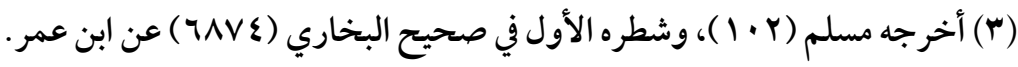




\section{क人}

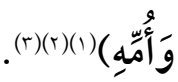

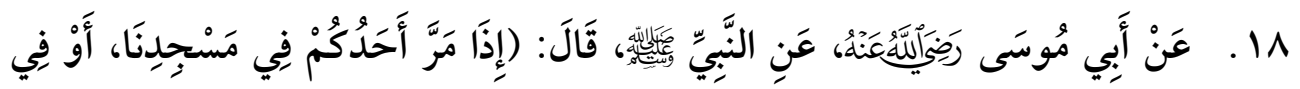

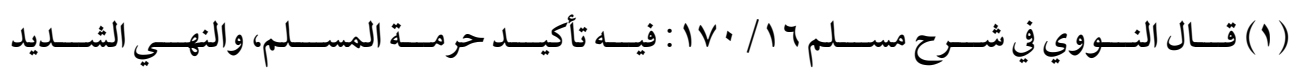

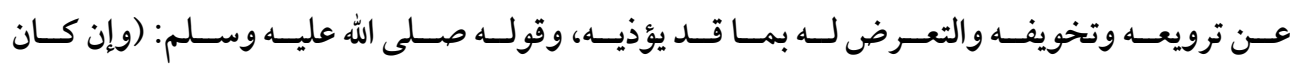

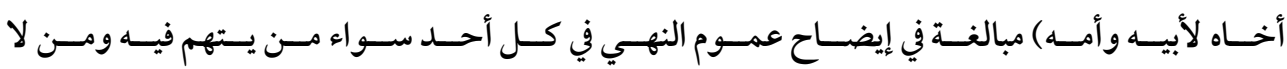

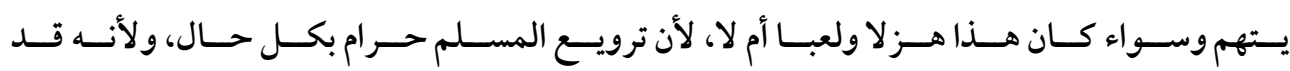
يسبقه السلاح كما صرح به في الرواية الأخرى، ولعن الملائكة له يدل على أنه حرام.

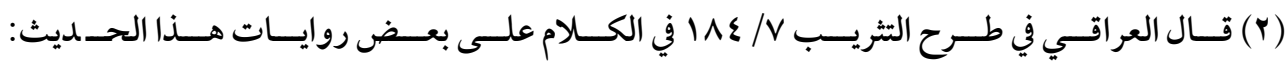

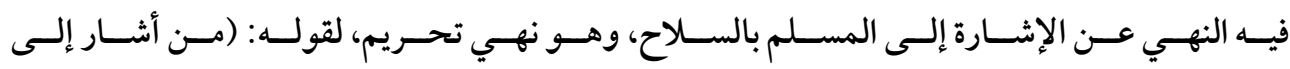

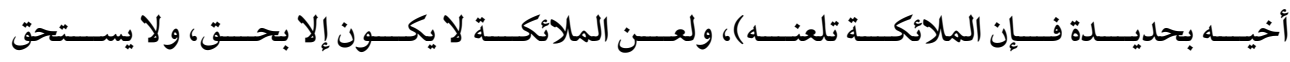

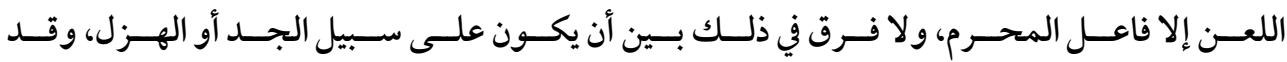

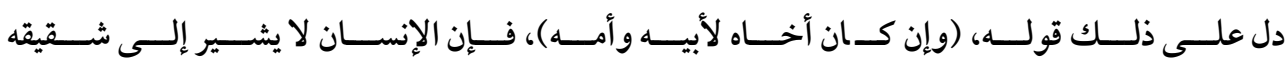

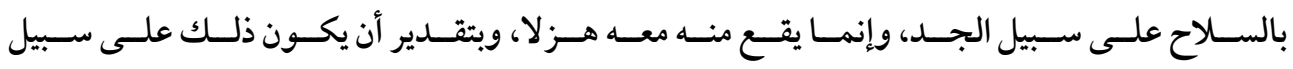

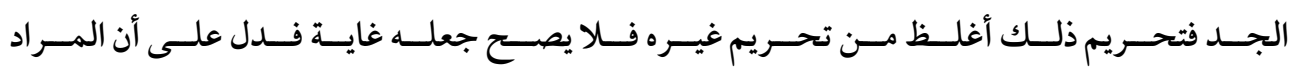

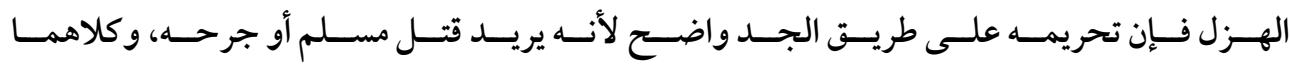

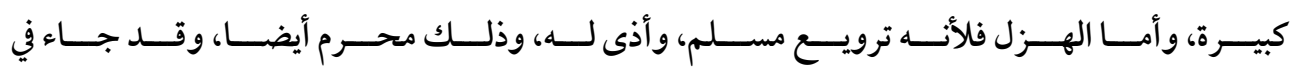

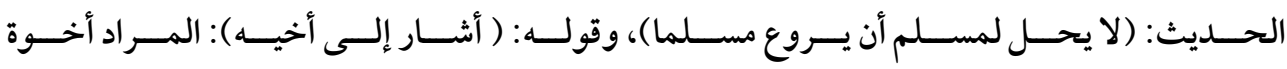

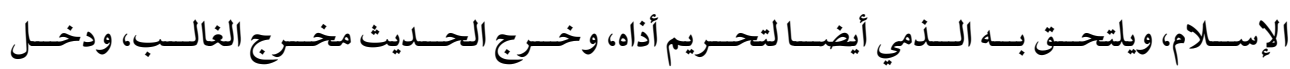

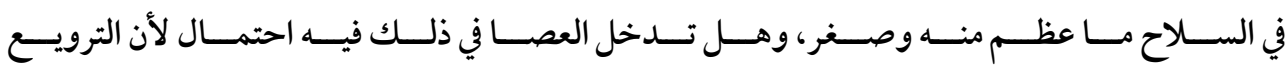

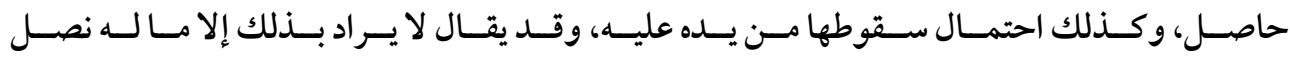

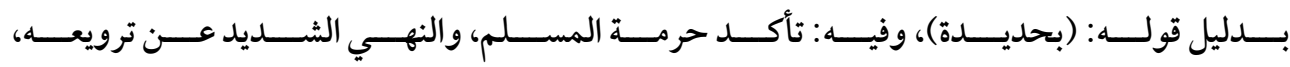
وتخويفه، والتعرض له بما قد يؤذيه. إ.هـ. باختصار يسير.

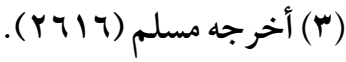




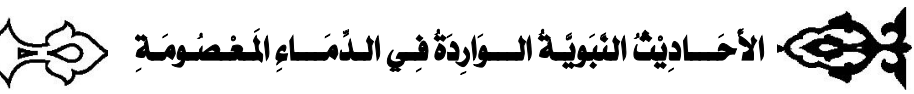

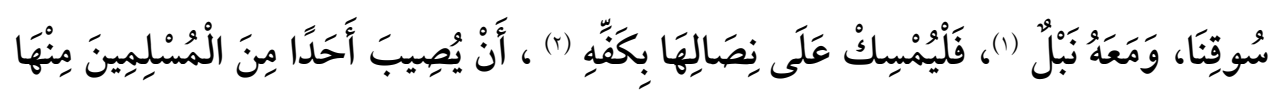

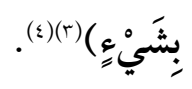

\section{الترهيب من رمي المسلمين بمقدوفات أو متفجرات أو أي سلاح}

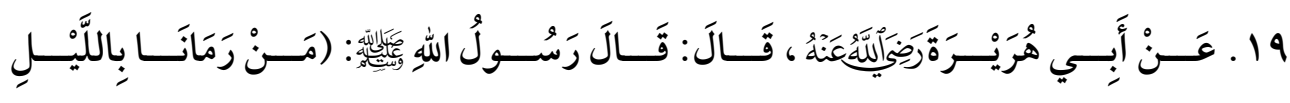
فَلَيْنَ مِنَّا) (o)

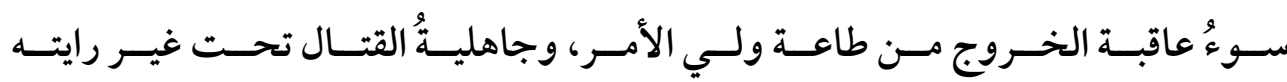

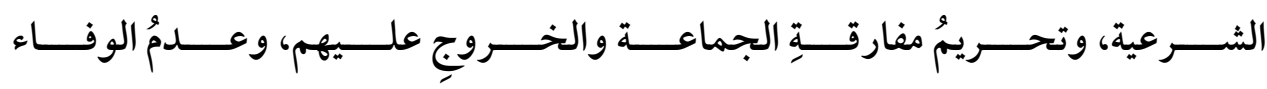
بالعهود

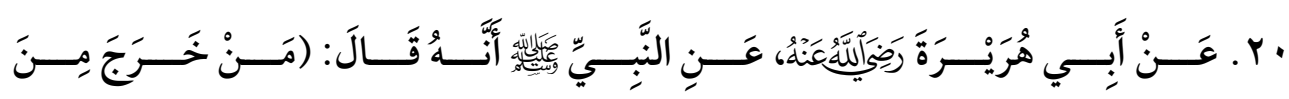

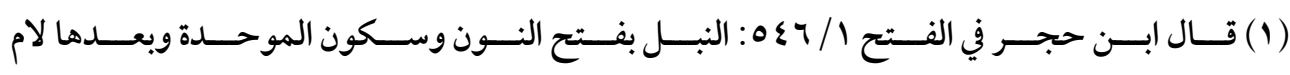
السهام العربية وهي مؤثنة ولاو واحد لها من لفظها.

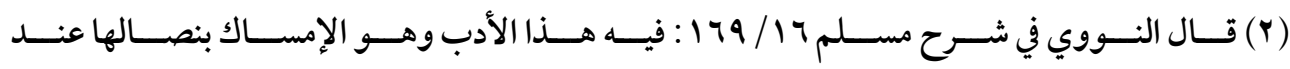

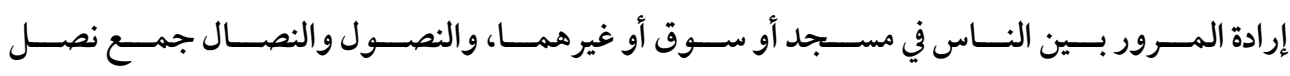
وهو حديدة السهم، وفيه اجتناب كل ما يخاف منه ضرر.

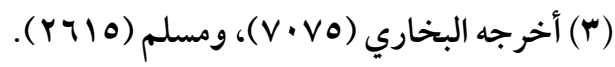

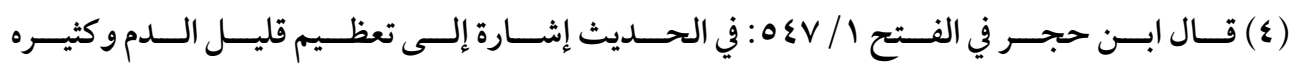

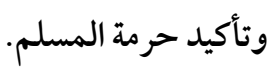

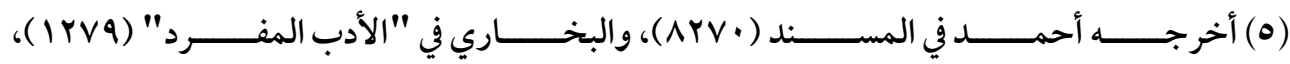

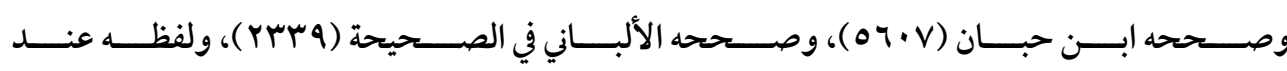
ابن حبان: من رمانا بالنبل.

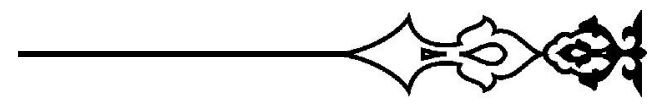




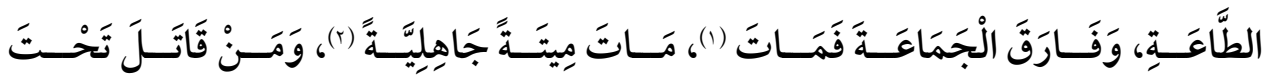

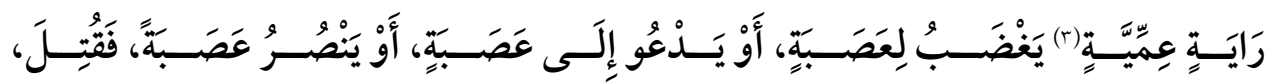

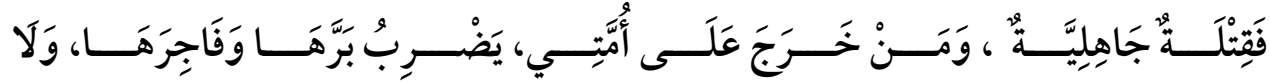

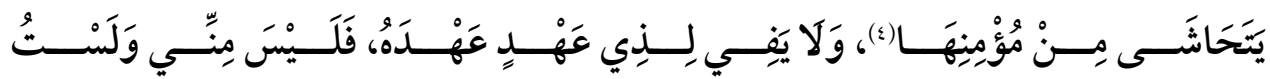
مِ مِنْهُ (०)

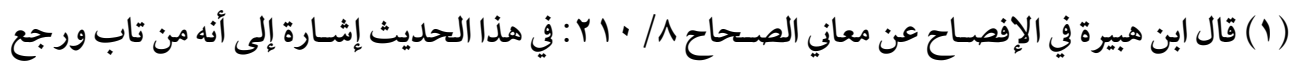
إلى الجماعة وطاعة الإمام قبل أن يموت، خرج عن هذا الوعيد لأن الفاء من حروف العطف من غير مهلة.

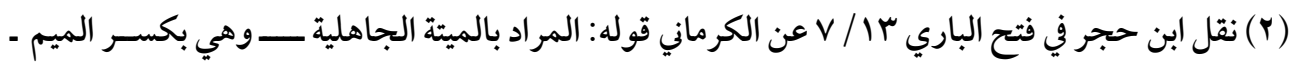

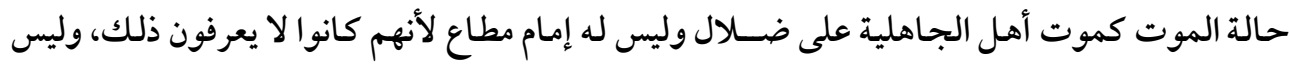

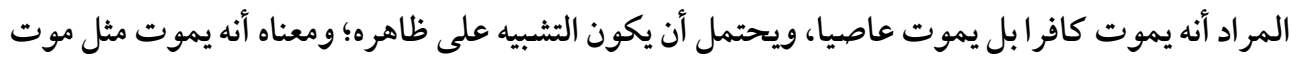
الجاهلي وإن لم يكن هو جاهليا، أو أن ذلك ورد مورد الزجر والتنفير وظاهره غير مراد، ويؤيد أن المراد

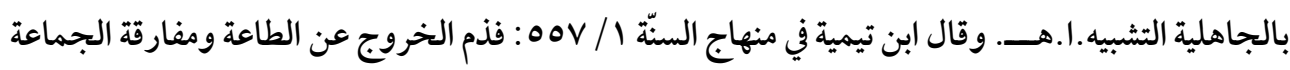
وجعل ذلك ميتة جاهلية؛ لأن أهل الجاهلية لم يكن لهم رأس يجمعهم.

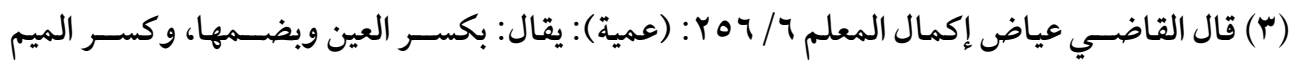

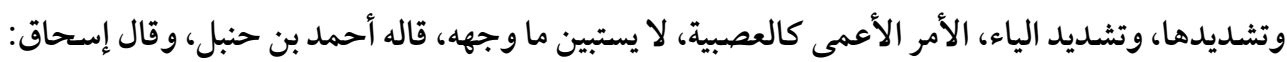

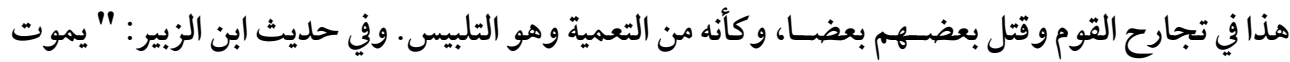

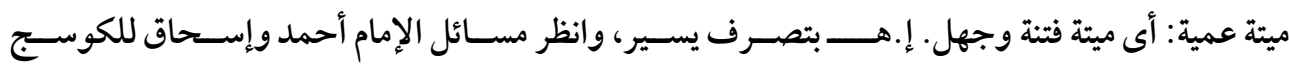
. $r \leqslant$ r/v

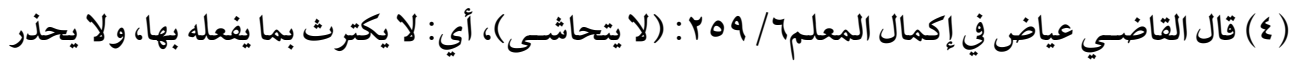
من عقباه، إنما يقاتل لشهوة نفسه وغَضَبِهِ أو لقومه وَعصبَّه، هذا - والله أعلم - في الخوارج وأثباههم من

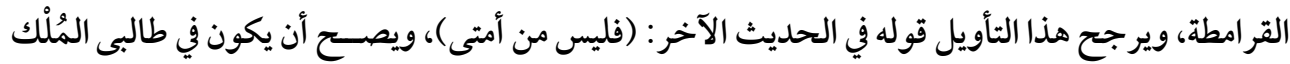

$$
\text { في الثوار في الأطر اف. أ.هـ. بتصرف يسرير. }
$$

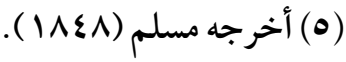



الزجرُ الشديد عن قتل من قال لا إله إلا الله، وحملُ النّاس على الظاهر، والله يتولى سرائرهم

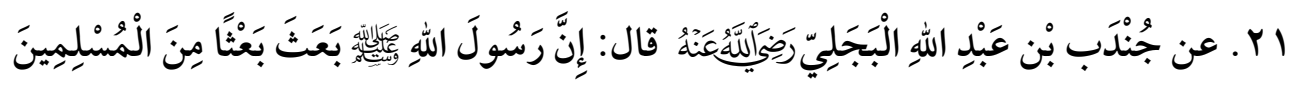

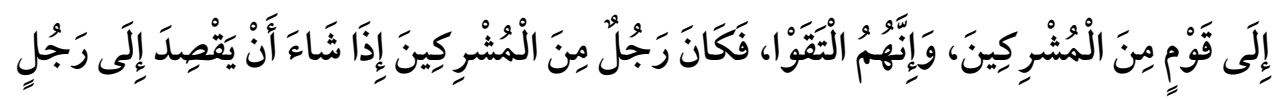

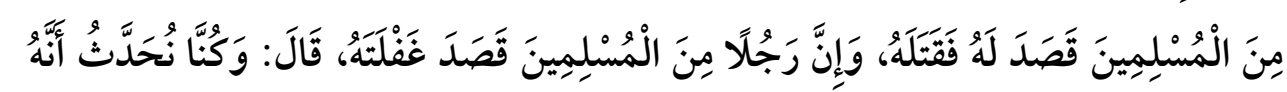

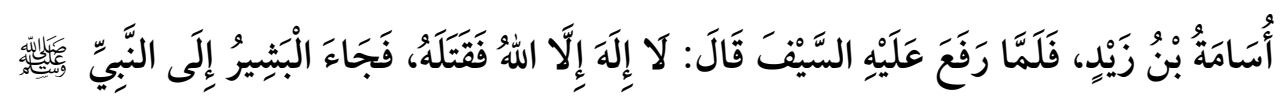

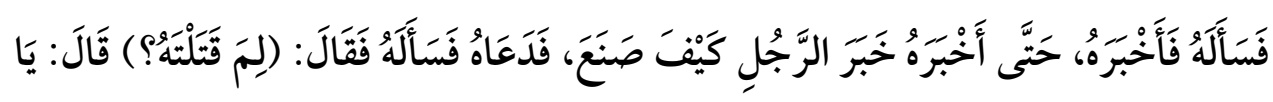

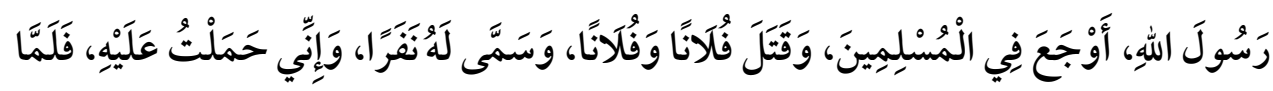

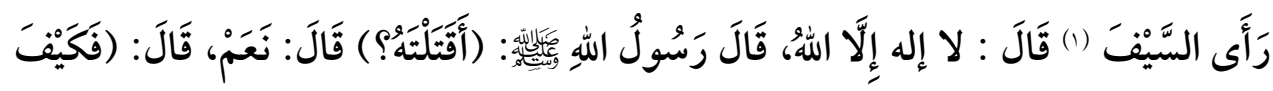

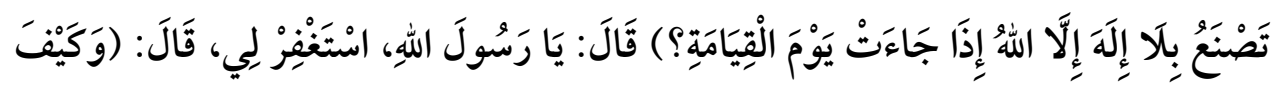

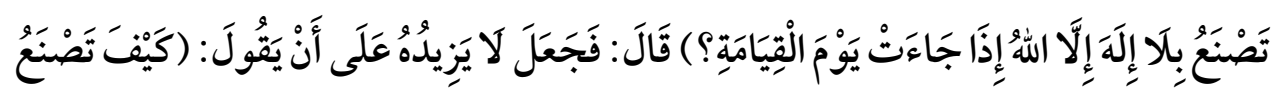

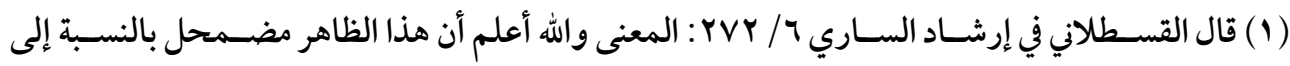
القلب، لأنه لا يطلع على ما فيه إلا الله، ولعل هذا أسـلم حقيقة وإن كان تحت السـيف، ولا يمكن دفع هذا

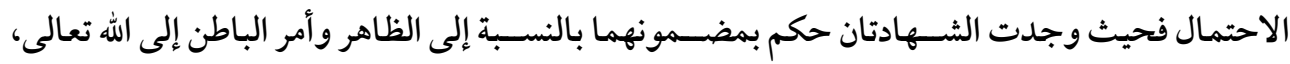
فالإقدام على قتل المتلفظ بهما مع احتمال أنه صـادق فيما أخبر به عن ضـميره فيه ارتكاب ما لعله يكون ظلمًا له، فالكف عن القتل أولى، والشارع عليه الصلاة والسلام ليس له غرض في إزهاق الروح بل في الهداية والإرشـاد، فإن تعذرت بكل سـبيل تعين إزهاق الروح لزوال مفسـدة الكفر من الوجود، ومع التلفظ بكلمة الحق لم تتعذر الهداية حصـلت أو تحصـل في المسـتقبل، فمادة الفسـاد الناشسئ عن كلمة الكفر قد زالت

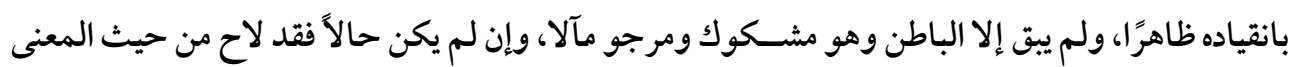
وجه قبول الإسلام اهـ. ملخصًا من المصابيح فيما نقله عن التاج ابن السبكي. 


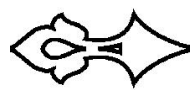

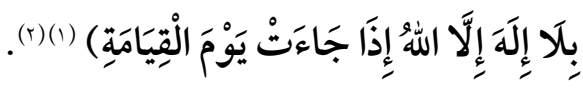

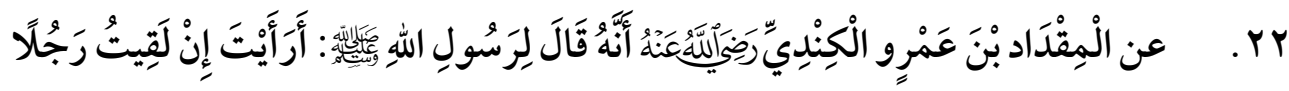

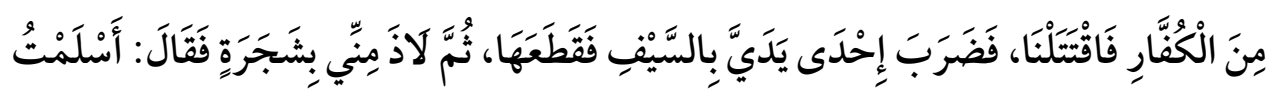

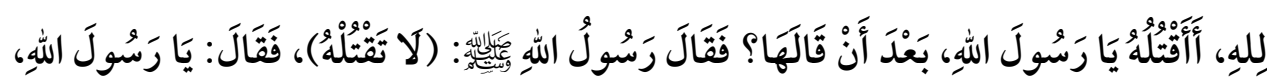

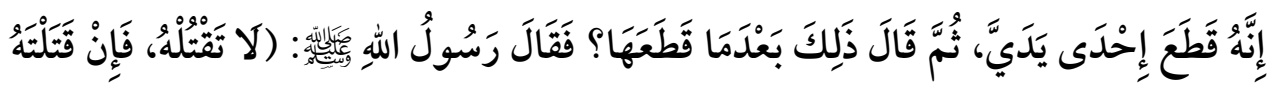

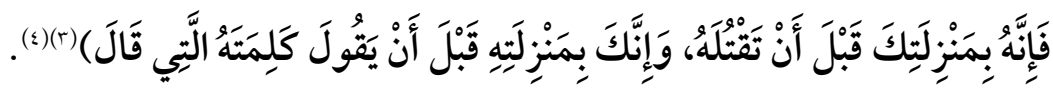

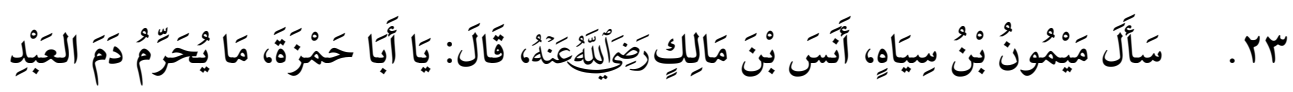

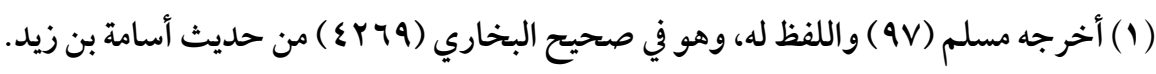

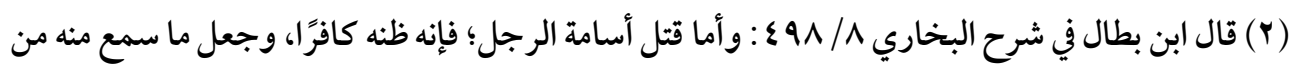

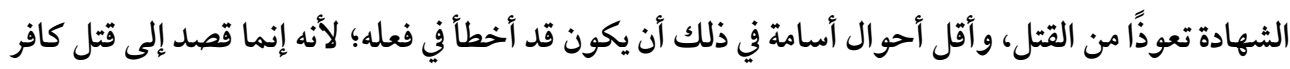

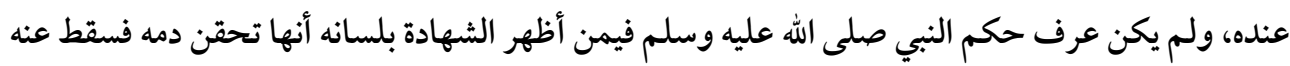

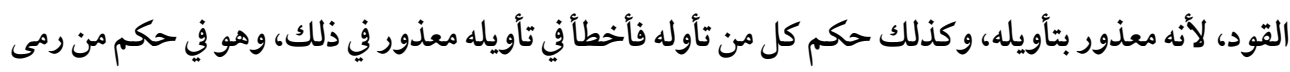

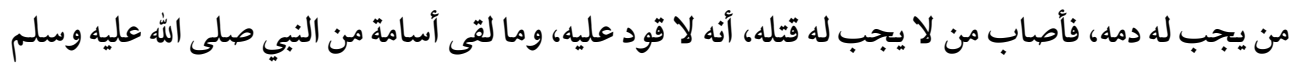

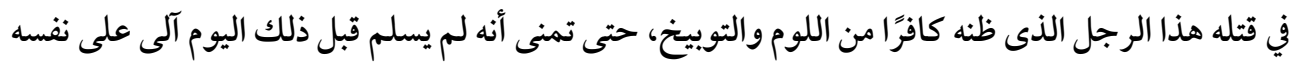

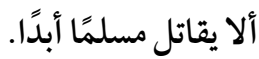

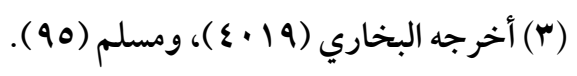

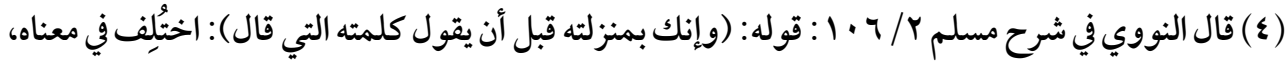

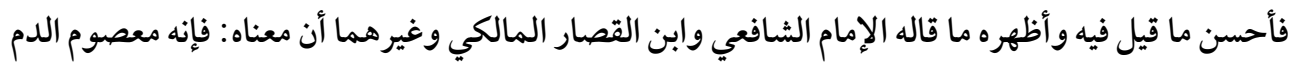

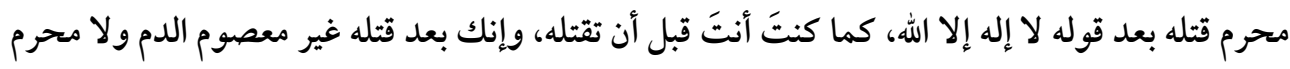

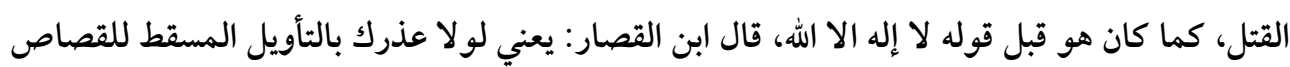

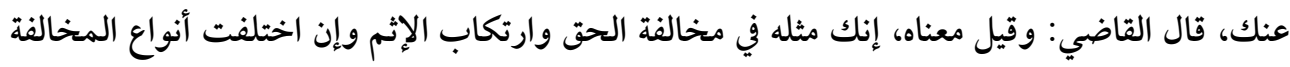

$$
\text { والإثم، فيسمى إثمه كفر ا وإثمك معصية وفسقا. }
$$

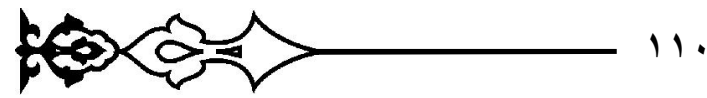




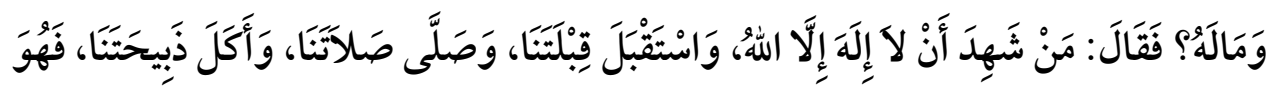

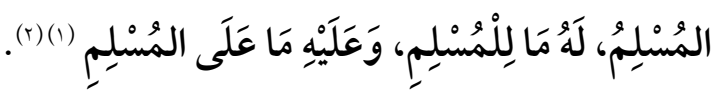

\section{الإيمان يمنع أهله من الاغتيالات والغدر}

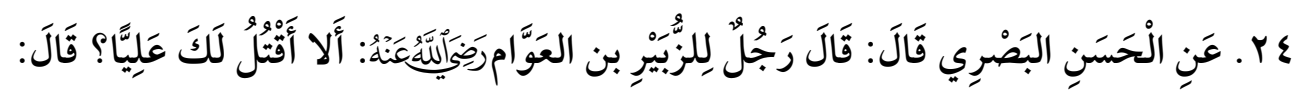

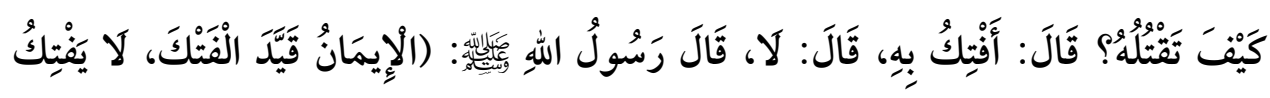

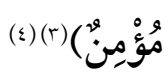

(1) أخرجه البخاري (rar) هكذا موقوفا على أنس، وورد عن أنس مرفوعا للنبي صلى الله عليه وسلم، (ألما

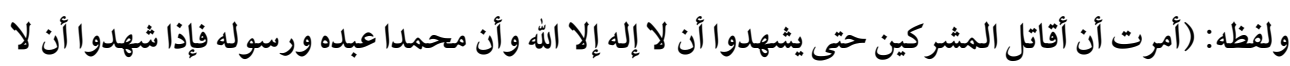
إله إلا الله وأن محمدا عبده ورسوله، وصلوا صلاتنا واستقبلوا قبلتنا وأكلوا ذبائحنا فقد حرمت علينا دماءهم

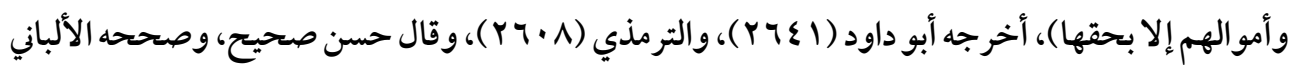

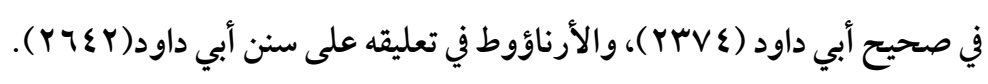

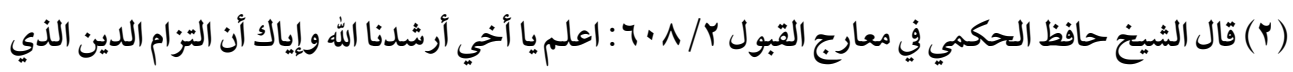

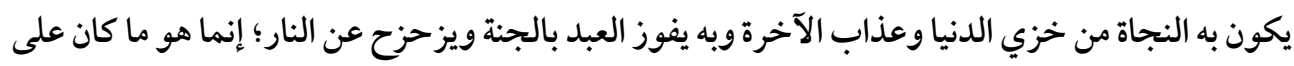

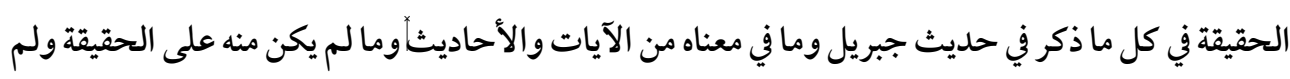

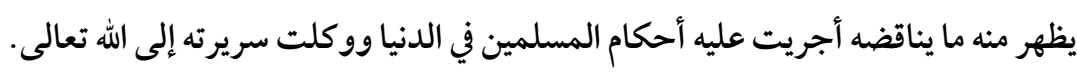

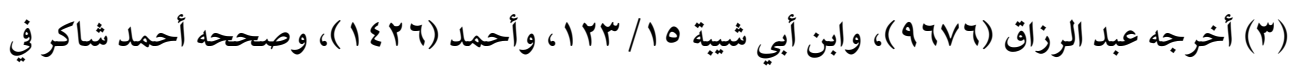

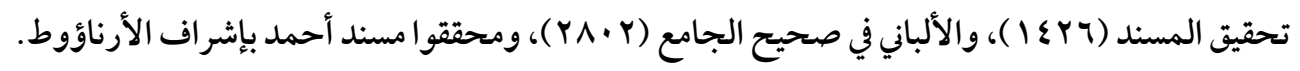

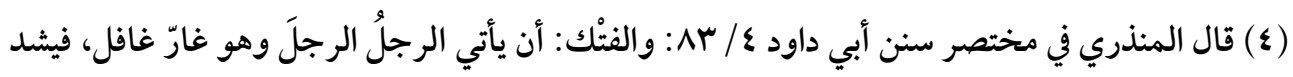

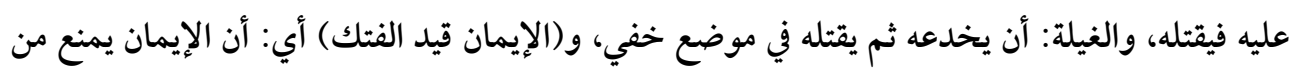

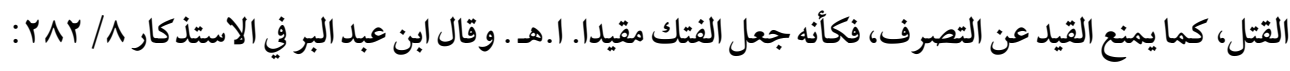

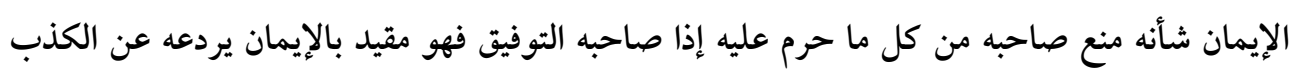




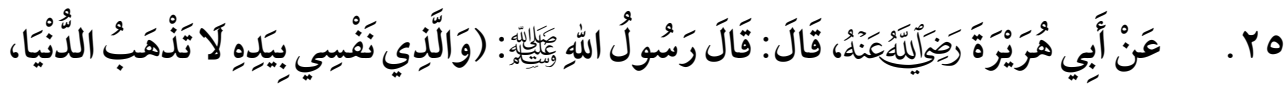

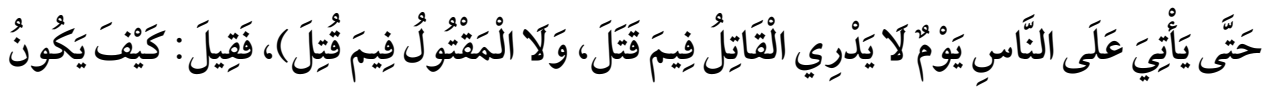

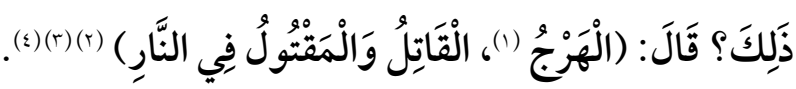
الوعيد الشديد من تفجير الشخص نفسه أو قتلها بأي طريقة، وتنوع عقوبة المنتحر في النار، والفجور والآثام كما قال رسول الله صلى الله عليه وسلم الإيمان قيد الفتك لا يفتك مؤمن والفتك القتل بعد الأمان والغدر بعد التأمين. ا.هـ. (1) الهرج هو القتل، كما ذكر في أحاديث أخرى في الصحيحين، وقد ذكر ابن سيده في المحكم ع / 109

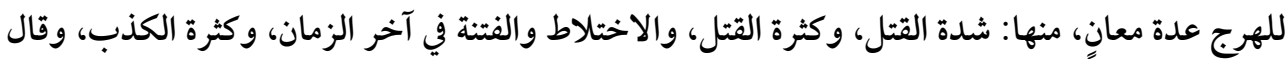
الجوهري في الصحاح / / • هץ: أصل الهرج الكثرة في الشيء، يعني حتى لا يتميز.

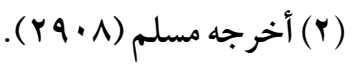

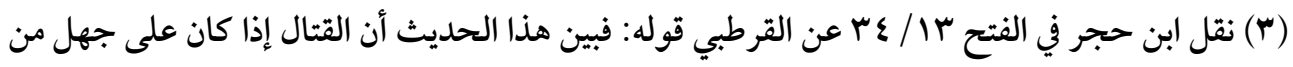
طلب الدنيا أو اتباع هوى فهو الذي أريد بقوله القاتل والمقتول في النار .

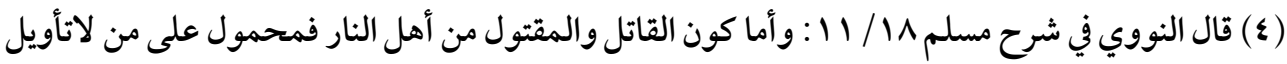
له ويكون قتالهما عصبية ونحوها، ثم كونه في النار معناه مستحق لها، وقد يجازى بذلك وقد يعفو الله تعالى عنه، هذا مذهب أهل الحق، وعلى هذا يتأول كل ما جاء من نظائره، واعلم أن الدماء التي جرت بين الصحابة بهابة رضي الله عنهم ليست بداخلة في هذا الوعيد، ومذهب أهل السنة والحق إحسان الظن بهم والإمساك عما شجر بينهم وتأويل قتالهم وأنهم مجتهلون متأولون لم يقصدوا معصية ولامحض الدنيا بل اعتقد كل فريق أنه المحق ومخالفه باغ فوجب عليه قتاله ليرجع إلى أمر الله، وكان بعضهم مصيبا وبعضهم مخطئا معذورا في الخطأ لأنه لاجْتِهادِ، و المجتهد إذا أخطأ لا إثم عليه، و كان علي رضي الله عنه هو المحق المصيب في تلك الحروب، هذا مذهب أهل السنة، وكانت القضايا مشتبهة، حتى إن جماعة من الصحابة تحيروا فيها فاعتزلوا الطائفتين، ولم يقاتلو اولم يتيقنوا الصواب، ثم تأخروا عن مساعدته منهم.

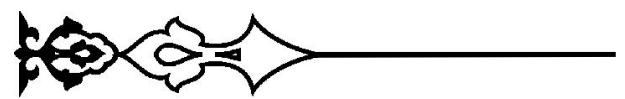




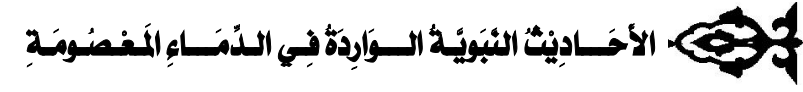

وتوعده بتحريم الجنّة عليه

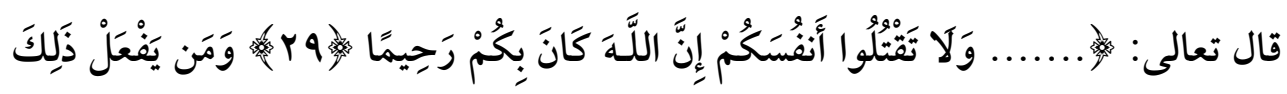

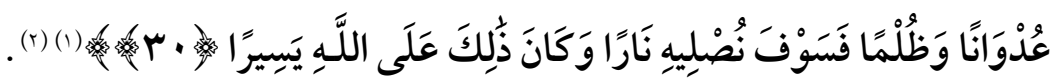

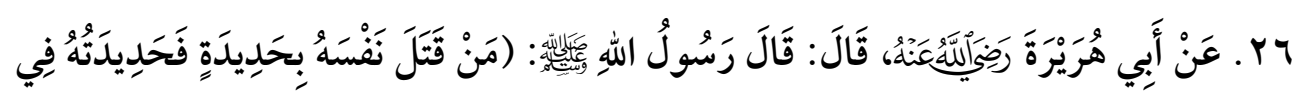

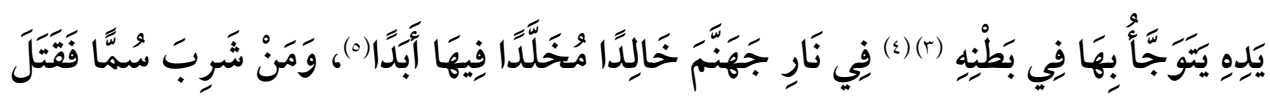

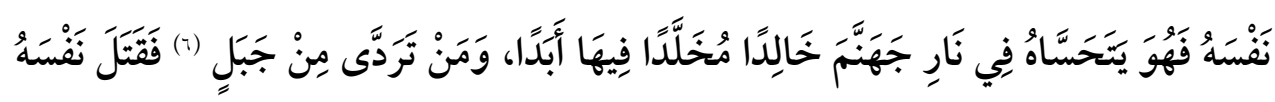

(1) - (1) سورة النساء.

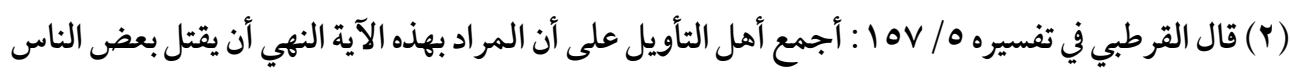

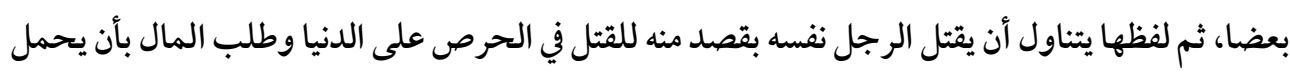

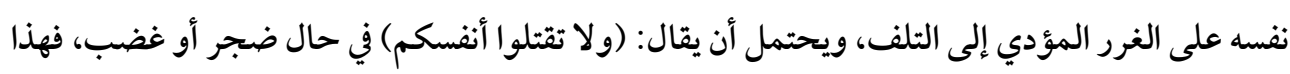

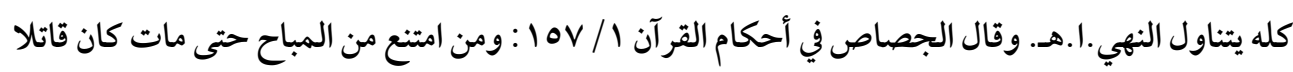

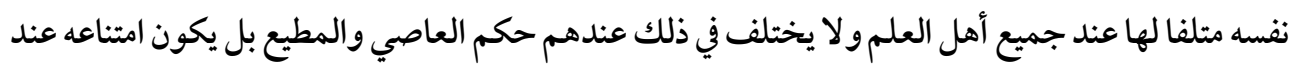
ذلك من الأكل زيادة على عصيانه.

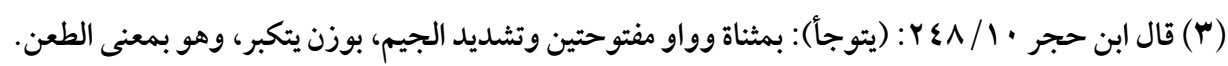

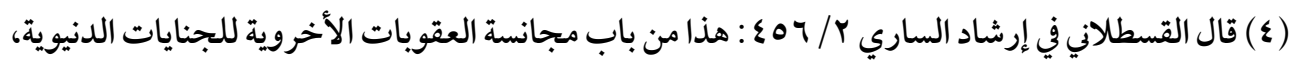

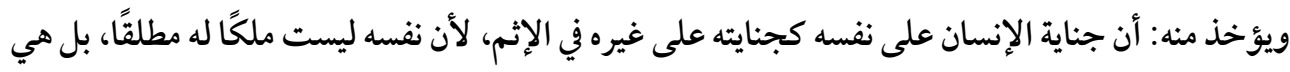

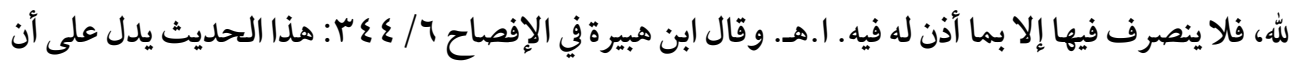

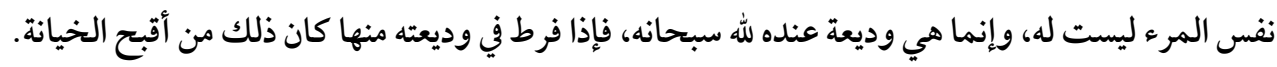

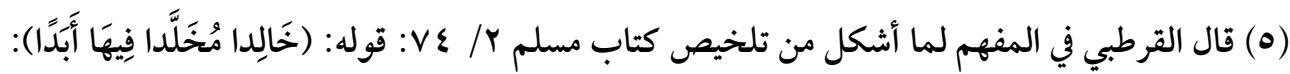

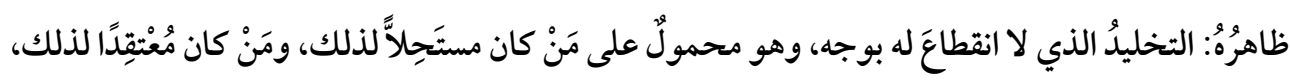

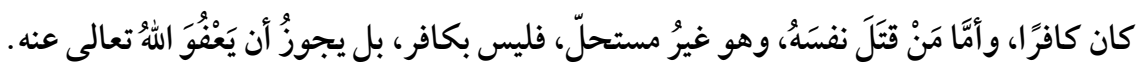

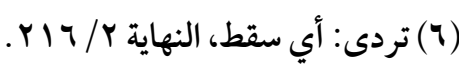




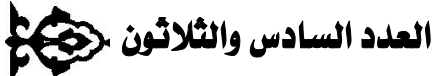

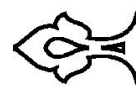

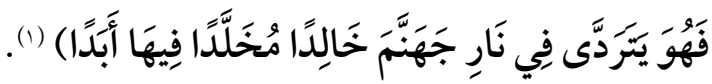

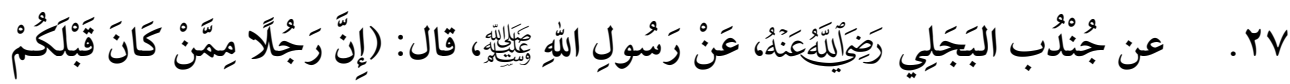

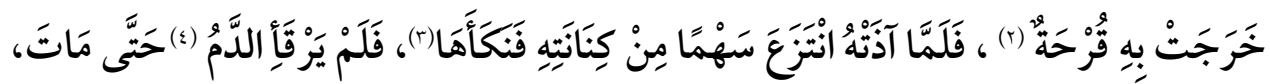

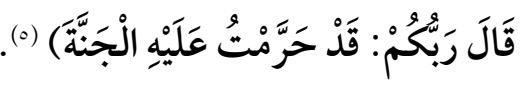

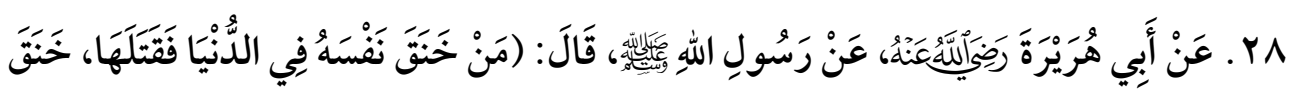

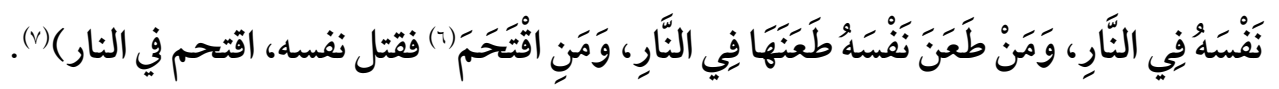

\section{قتل الرجل لقرابته في آخر الزمان ويحسب أنه على شيئ |!}

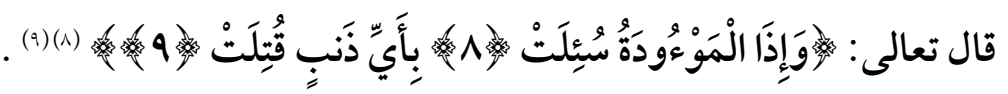

$$
\text { (1) (1) أخرجه البخاري (OVVA) )، ومسلم (1) (1) ). }
$$

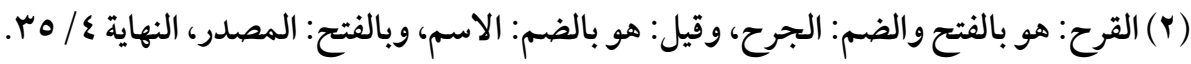

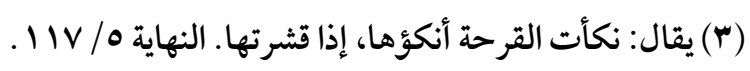

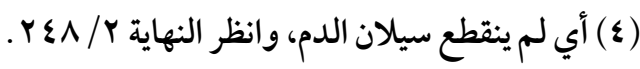

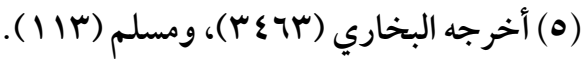

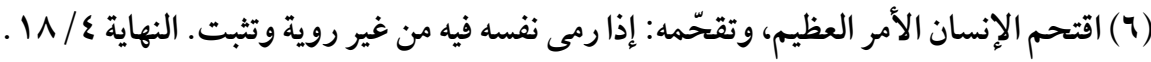

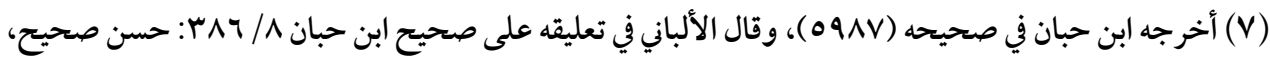

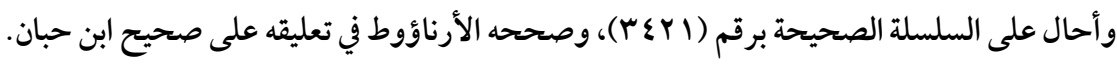

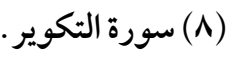

(9) قال ابن كثير في تفسيره / / بrr: الموعودة هي التي كان أهل الجاهلية يدسونها في التراب كراهية البنات،

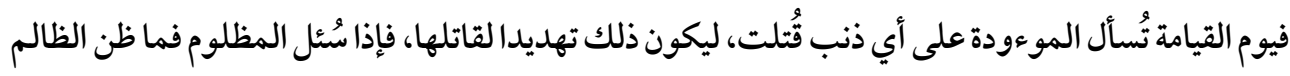

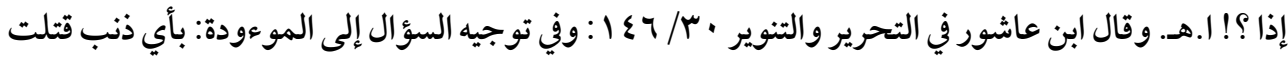

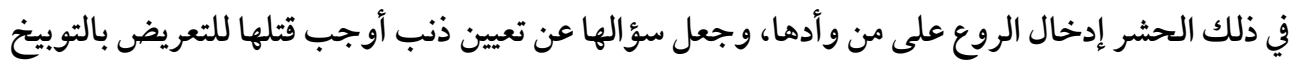
والتخطئة للذي وأدها وليكون جوابها شهادة على من وأدها فيكون استحقاقه العقاب أشد وأظهر.

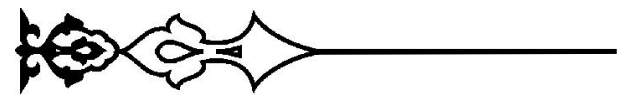




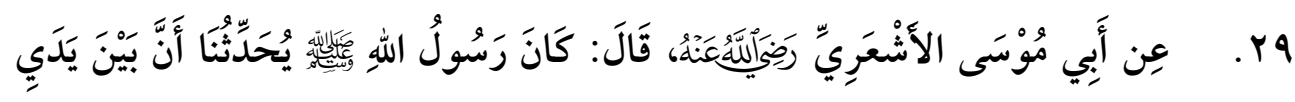

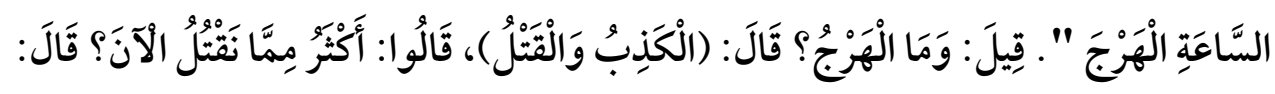

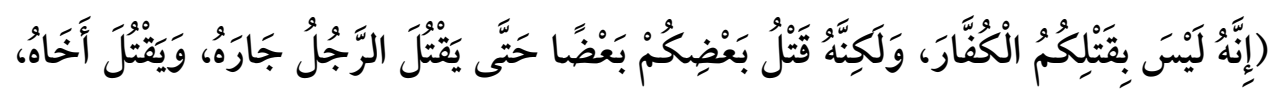

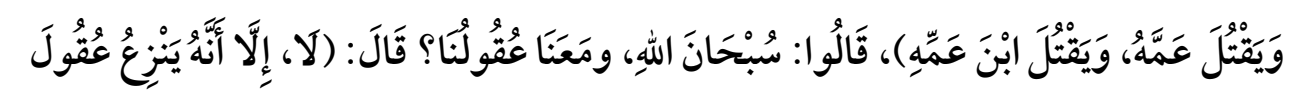

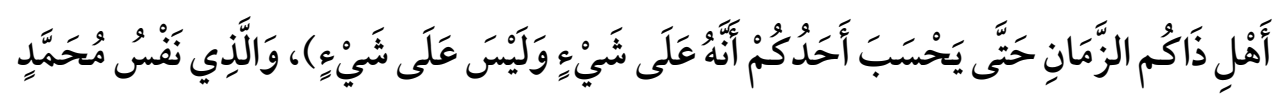

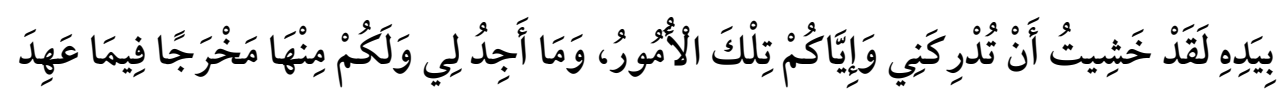

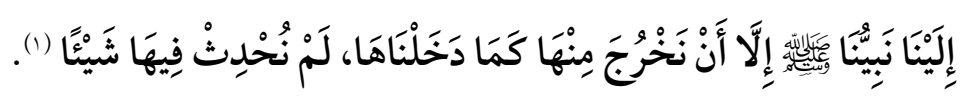
النهي عن قتل النساء والأطفال

.r.

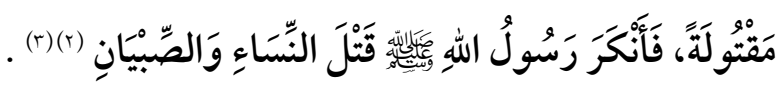

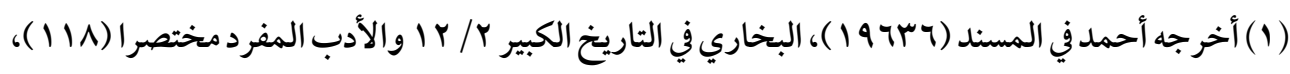

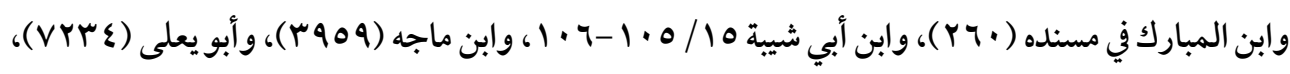

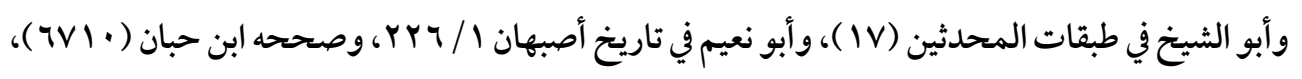

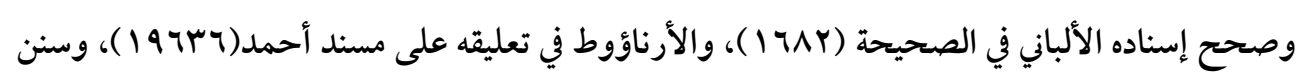

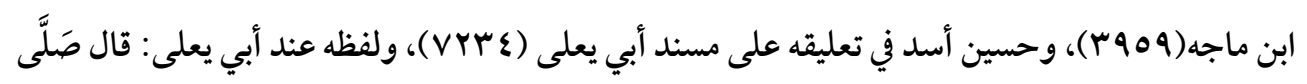

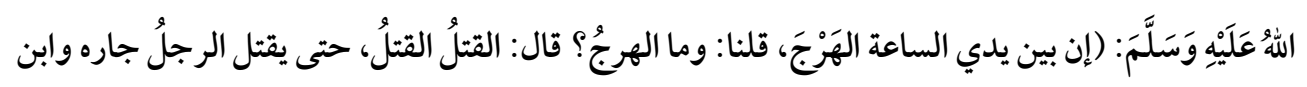

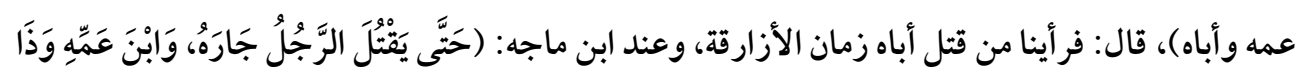
قَرَابَتِهِ).

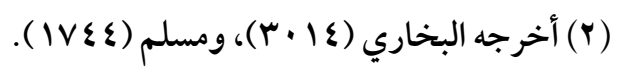

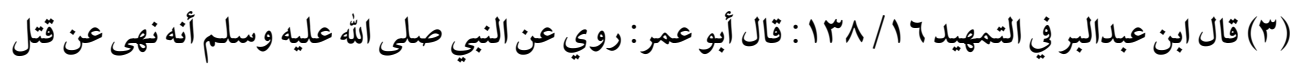

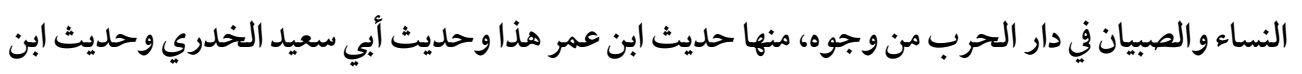

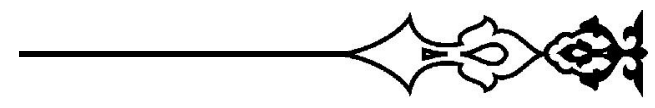




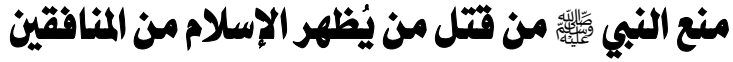

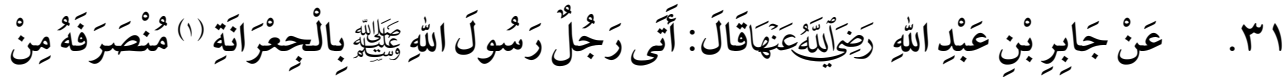

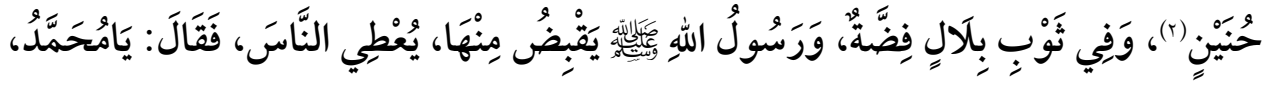

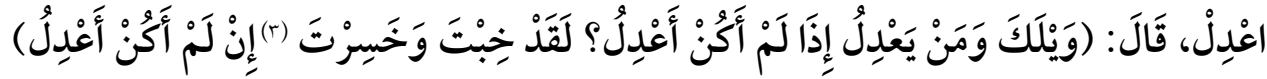

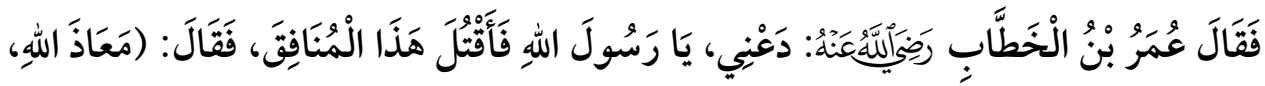

عباس وحديث عائشة وحديث الأسود بن سريع، وأجمع العلماء على القول بجملة هذا الحديث، ولا يجوز

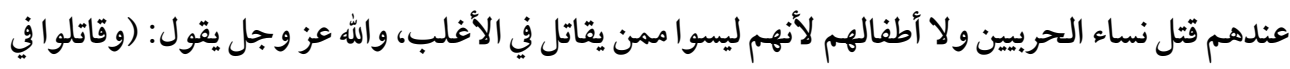
سبيل الله الذين يقاتلونكم)، واختلفوافي النساء والصبيان إذا قاتلوا افجمهور الفقهاء على أنهم إذا قاتلوا قتلوا وممن رأى ذلك الثوري والأوزاعي والليث والشافعي وأبو حنيفة وأحمد وإسحاق وأبو ثور وكل هؤلاء وغيرهم ينهون عن قتل النساء والصبيان إذا لم يقاتلوا اتباعا للحديث، والله أعلم، واختلفوا في طوائف ممن لا يقاتل فجملة مذهب مالك وأبي حنيفة وأصحابهما أنه لا يقتل الأعمى والمعتوه ولا المقعد ولا أصحاب الصوامع الذين طينو الباب عليهم ولا يخالطون الناس، قال مالك: وأرى أن يترك لهم من أمو الهم ما يعيشون به، ومن خيف منه شيء قتل، وقال الثوري: لا يقتل الشيخ ولا المر أة ولا المقعد ولا الطفل، وقال الأوزاعي: لا يقتل الحراث والزراع ولا الشيخ الكبير ولا المجنون ولا راهب ولا امر أة، وقال الليث: لا يقتل الر اهب في صومعته، ويترك له من ماله القوت. (1) الجعرّ انة: بكسر الجيم و كسر العين المهملة وتشديد الراء، وفيها رواية أخرى وهي كسر الجيم وسكون

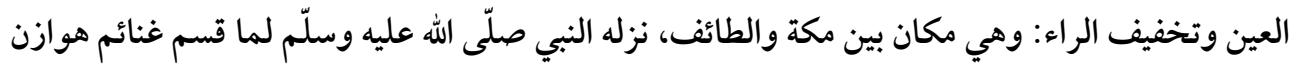
مرجعه من غزاة حنين، وأحرم منها، ويقع شمال شرقي مكة. انظر المعالم الأثيرة •9.

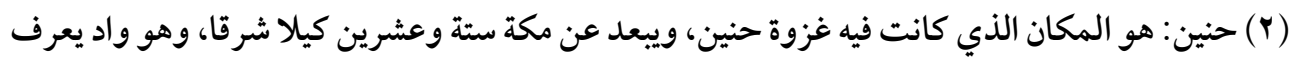

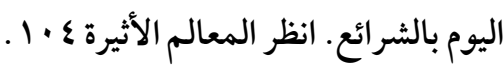

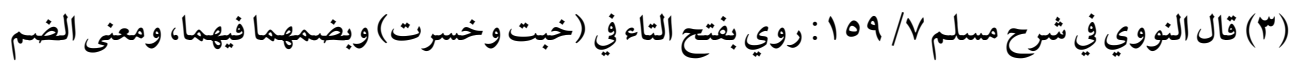
ظاهر، وتقدير الفتح خبتَ أنتَ أيها التابع إذا كنتُ لا أعدل لكونك تابعا ومقتديا بمن لا يعدل، والفتح أشهر. 


\section{$\overbrace{0}^{3}$}

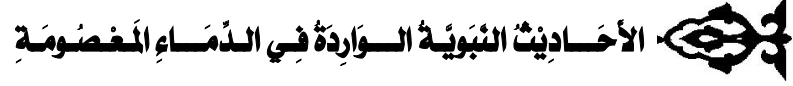

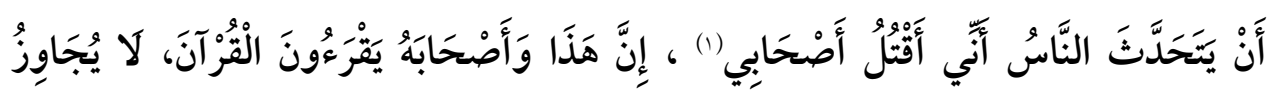

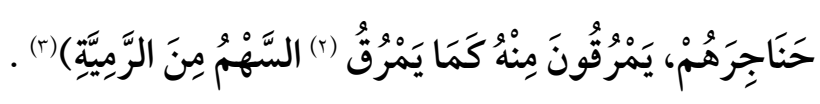

( ) قال ابن تيمية في كتاب الإيمان VY Y بشأن لفظة (أصحابي)، قال: لأنهم من أصحابه في الظاهر عند من لا يعرف حقائق الأمور، وأصحابه الذين هم أصحابه ليس فيهم نفاق، وقال في · سم: إن البي صلى الله عليه وسلم كان يمتنع من عقوبة المنافقين، لأن فيهم من لم يكن يعرفهم كما أخبر الله بذلك، والذين كان يعرفهم لو عاقب بعضهم لغضب له قومه، ولقال الناس: إن محمدًا يقتل أصحابه، فكان يحصل بسبب ذلك نفور

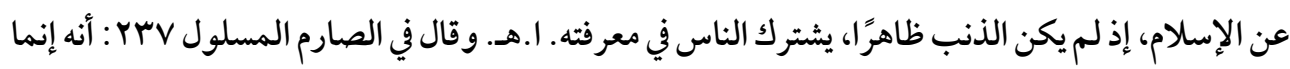
لم يقتلهم لئلا يتحدث الناس أن محمدا يقتل أصحابه فإن الناس ينظرون إلى ظاهر الأمر فيرون واحدا من أصحابه قد قتل فيظن الظان أنه يقتل بعض أصحابه على غرض أو حقد أو نحو ذلك فينفر الناس عن الدخول في الإسلام وإذا كان من شريعته أن يتألف الناس على الإسلام بالأموال العظيمة ليقوم دين الله وتعلو كلمته

$$
\text { فلأن يتألفهم بالعفو أولى وأحرى. ا.هـ. }
$$

ونقل ابن حجر في الفتح Y / / 1 Y : قول الإسماعيلي بشأن قتال الخوارج: أنهم إذا أظهروا رأيهم ونصبوا للناس القتال وجب قتالهم، وإنما ترك النبي صلى الله عليه وسلم قتل المذكور لأنه لم يكن أظهر ما يستدل به على ما وراءه، فلو قتل من ظاهره الصلاح عند الناس قبل استحكام أمر الإسلام ورسوخه في القلوب لنفَّرَهم عن الدخول في الإسلام، وأما بعده صلى الله عليه وسلم فلا يجوز ترك قتالهم إذا هـم أظهروا رأيهم وتر كوا الجماعة وخالفوا الأئمة مع القدرة على قتالهم، قال ابن حجر : وقد ذكر ابن بطال عن المهلب قال التألف إنما كان في أول الإسلام إذا كانت الحاجة ماسة لذلك لدفع مضرتهم فأما إذ أعلى الله الإسلام فلا يجب التألف إلا أن تنزل بالناس حاجة لذلك فلإمام الوقت. (ץ) قال بن بطال في شرح البخاري / / ^م: قوله: (يمرقون من الدين) فالمروق عند أهل اللغة الخروج يقال: مرق من الدين مروقًا خرج ببدعة أو ضلالة، ومرق السهم من الغرض إذا أصابه ثم نقره، أي خرج منه.

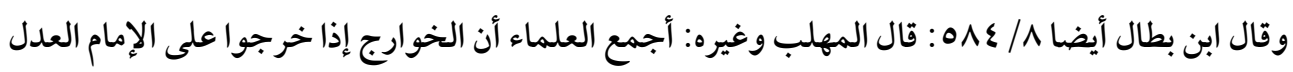

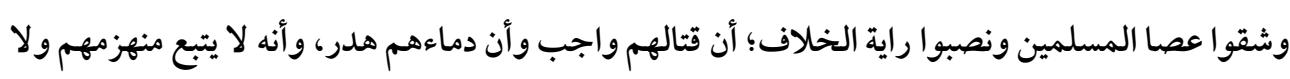
يجهز على جريحهم. قال مالك: إن خيف منهم عودة أجهز على جريحهم وأتبع مدبرهم، وإنما يقاتلون من أجل خروجهم على الجماعة.

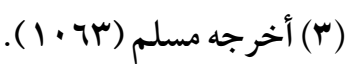


العداد السادس والثلاثون

\section{إثم من أنتى الناس حتى وتعوا في الدماء}

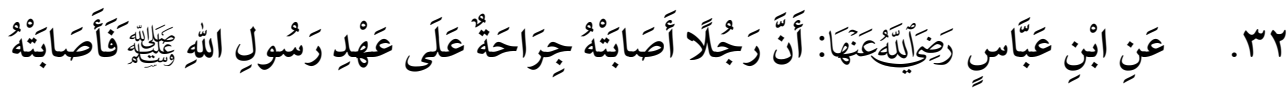

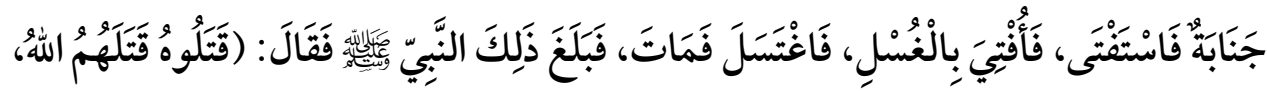

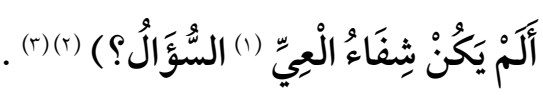

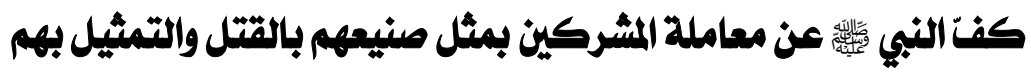

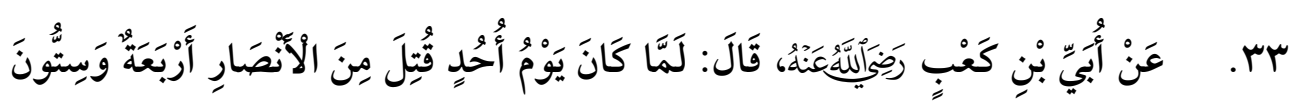

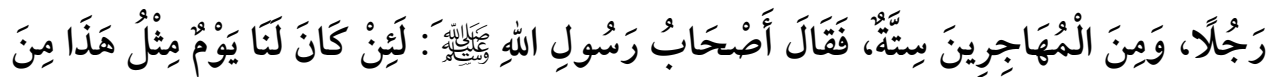

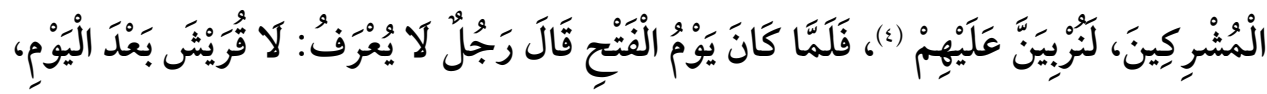

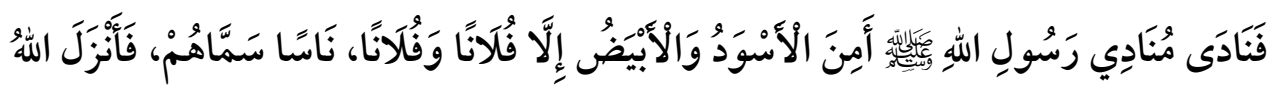

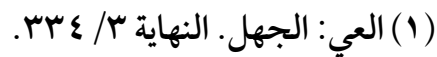

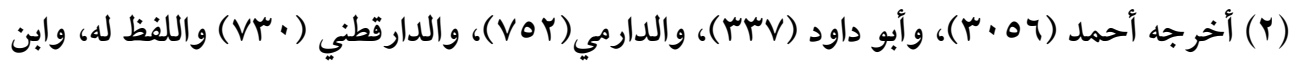

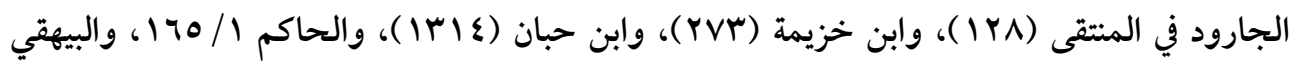

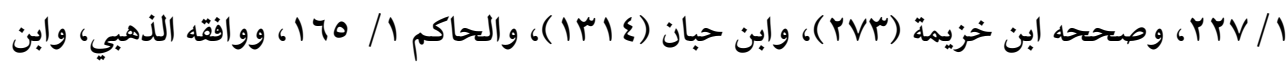

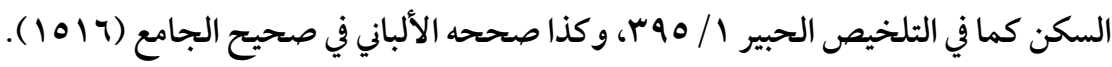

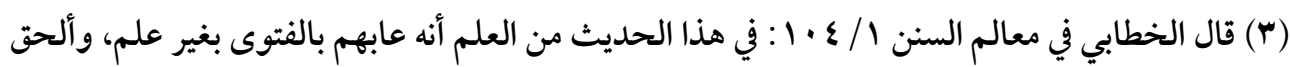
بهم الوعيد بأن دعاعليهم، وجعلهم في الإثم قتلة له. وقال ابن القيّم في مفتاح دار السعادة / / 111 : فجعل العيّ وهو عي القلب عن العلم واللسان عن النطق به

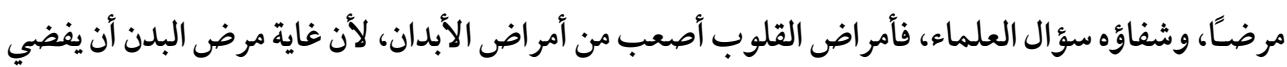
بصاحبه إلى الموت، وأما مرض القلب فيفضي بصاحبه إلى الشقاء الأبدي، ولا شفاء لهذا المرض إلا براي

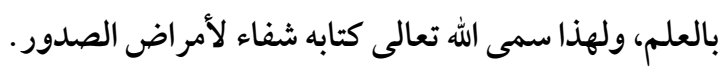

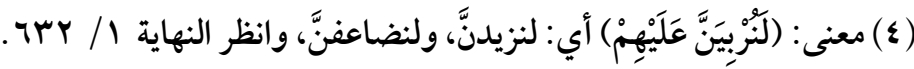

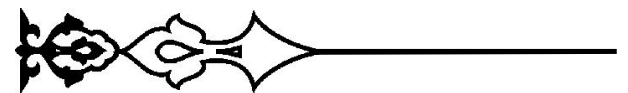




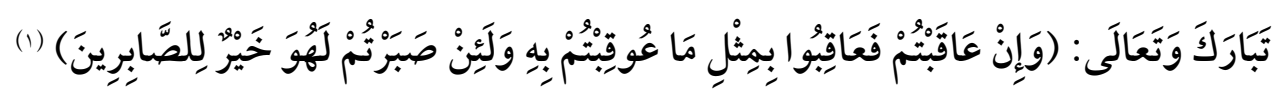

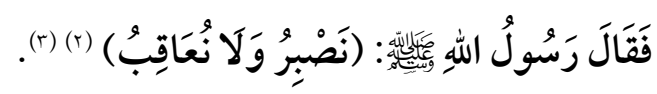

\section{حرمة تتل الكفار الدين أذن لهم ولي الأمر في دخول البلاد من المعاهدين والماتستامنين،}

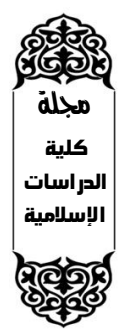

\section{وشناعة الغدربهم}

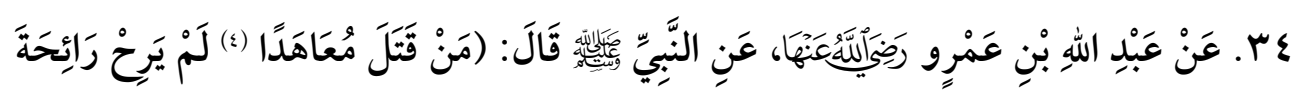

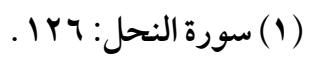

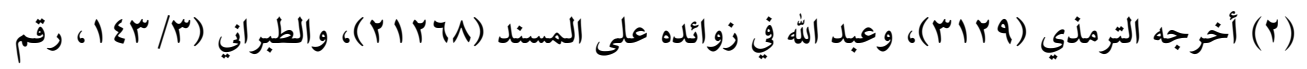

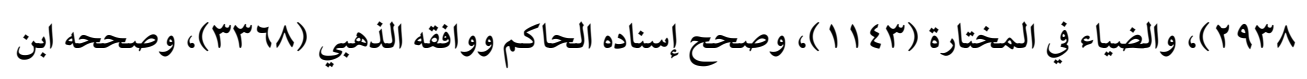

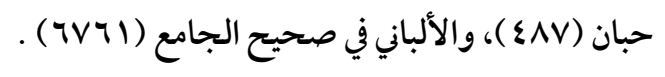

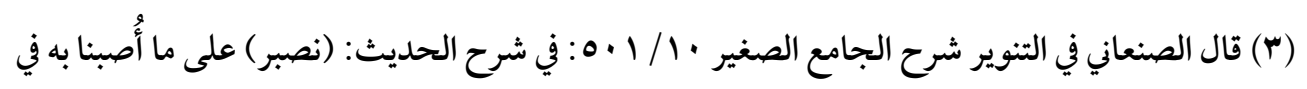
حمزة، والمُثلة به (ولانعاقب)، وذلك أنه صلى الله عليه وسلم لما مَثّل المشر كون بعمه حمزة رضي الله عنه يوم أحد، أقسم صلى الله عليه وسلم ليمثل بسبعين من أشر اف قريش، فأنزل الله (وَإِنْ عَاقَبَتمْ ...) الآية، فقال: (نصبر ....)، الحديث. وقال ابن حزم في المحلى • 1/ سד ץ: لا يحل العبث بابن آدم، فإذا عبث هو ظالما:

$$
\text { اقتص منه بمثل فعله - و كان حقا وعدلا. }
$$

( ع) قال ابن القيّم في أحكام أهل الذمّة Y / ه ؟ : الكفار: إمّا أهل حربٍ، وإمّا أهل عهدٍ. وأهل العهد ثلاثة أصناف: أهل ذمّة، وأهل هُدنة، وأهل أمانٍ. ا.هـ. وقال الشيخ ابن باز كما في مجموع فتاواه / / V • r : لايجوز قتل الكافر المستوطن أو الوافد المستأمن الذي أدخلته الدولة آمنًا، ولا قتل العصاة ولا التعدي عليهم، بل إن يحالون فيما يحدث منهم من المنكرات للحاكم الشرعي، وفيما تراه المحاكم الشرعية الكفاية. ا.هـ. وقال

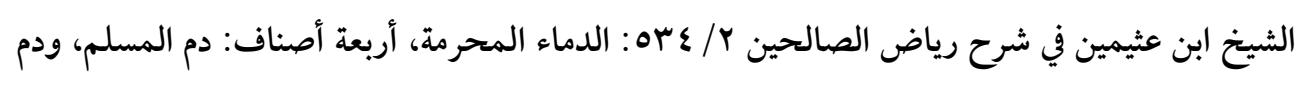
الذمي، ودم المعاهد، ودم المستأمن، وأشدها وأعظمها دم المؤمن، وقال في / IV / I : لا يجوز لأحد أن يتعدى على دم أحد، ولا على دم تفوت به النفس وهو القتل، ولا على دم يحصل به النقص، كدم الجروح، وكسر العظام، وما أشبهها، كل هذا حر ام لا يجوز ولئ.

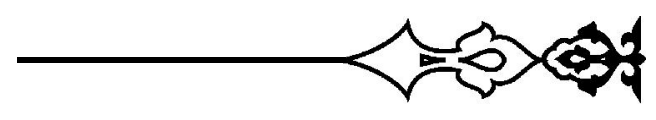




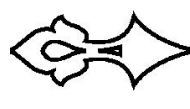

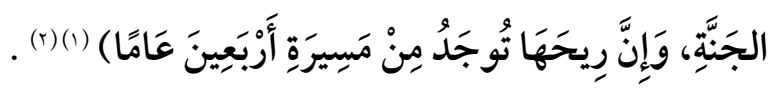

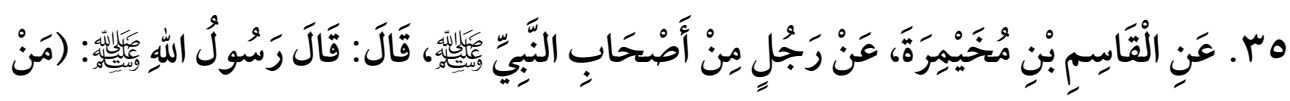

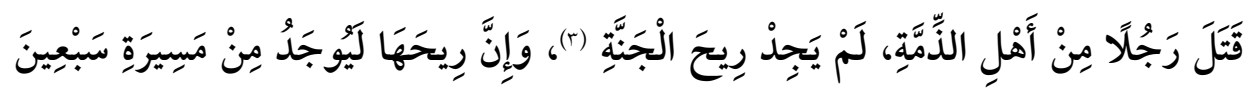

عَامًا)

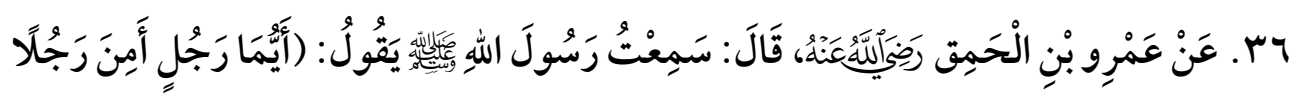

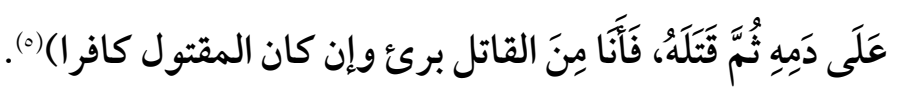

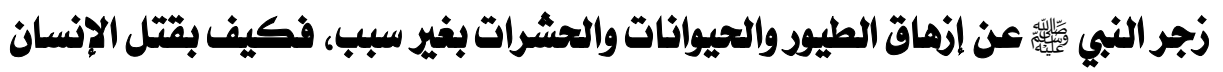

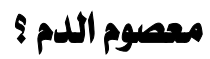

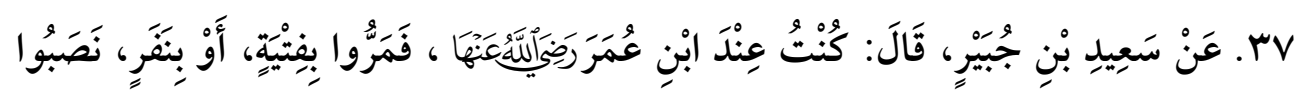

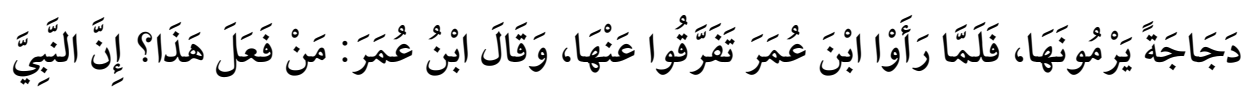

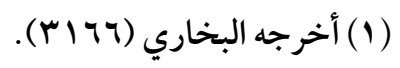

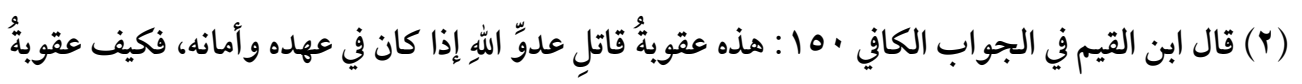

$$
\text { قاتلِ عبده المؤمن؟ }
$$

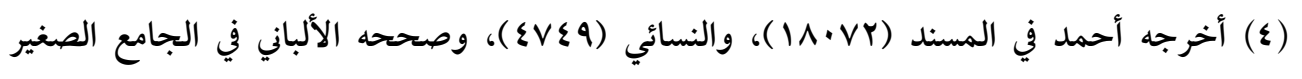

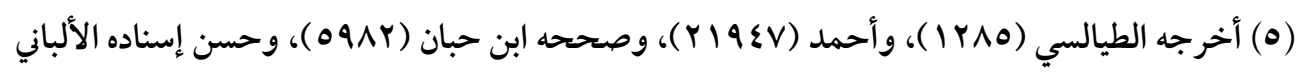

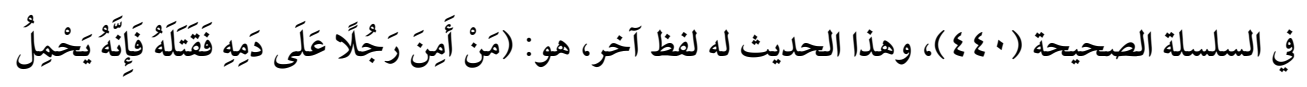

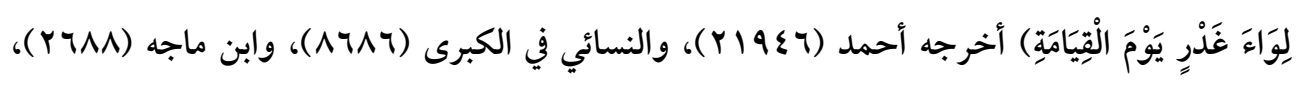

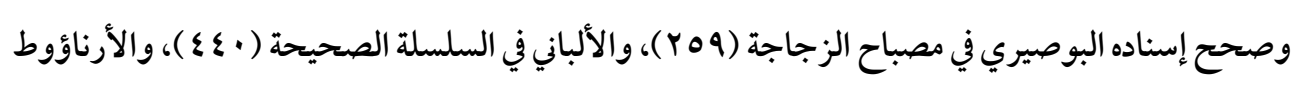

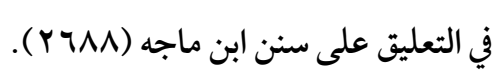

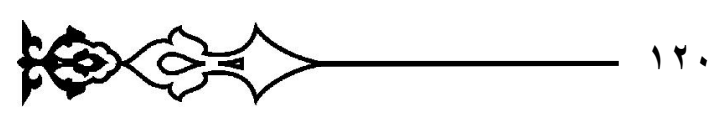




\section{هُ}

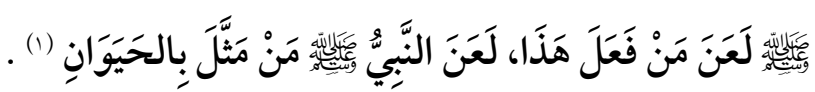

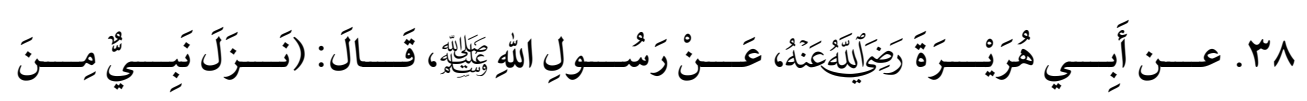

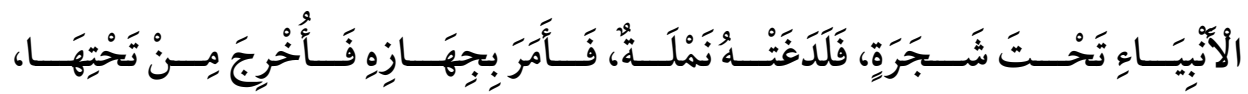

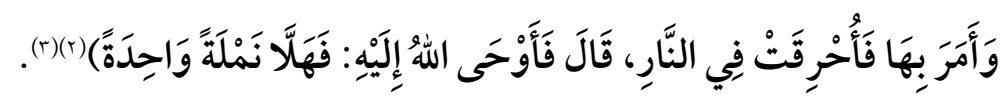

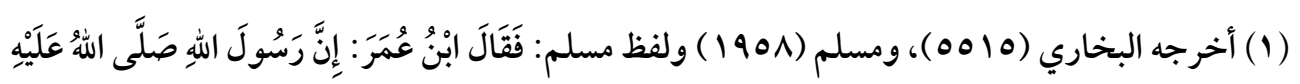

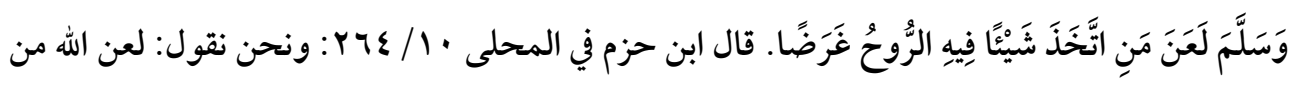
اتخذ شيئا فيه الروح غرضا إلا حيث أمر الله تعالى به من القصاص، فمن استحق لعنة الله لفعله ذلك، والاعتداء عليه بمثل ما اعتدى هو به.

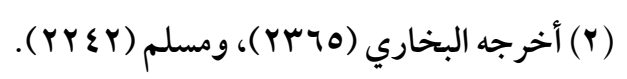

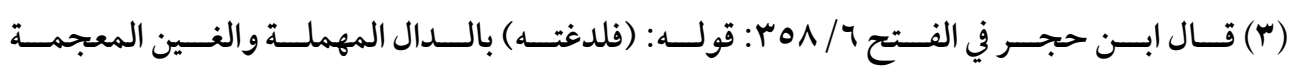

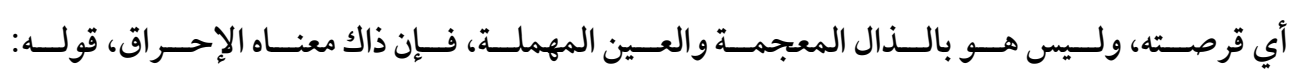

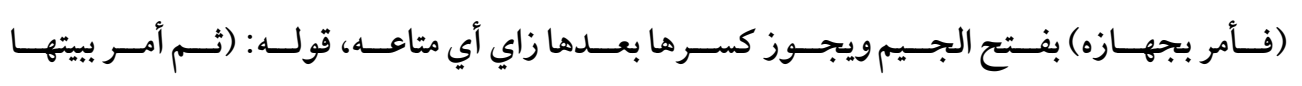

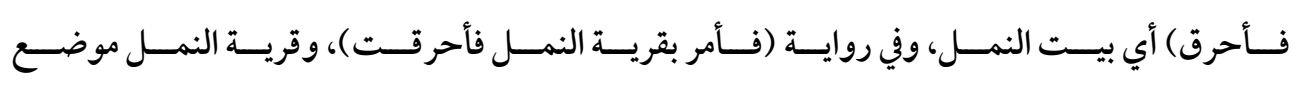

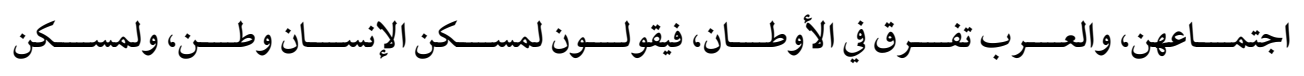

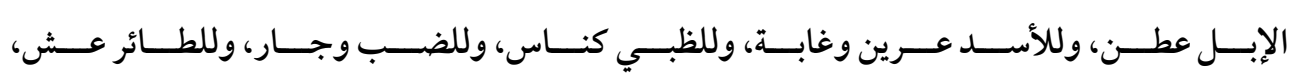

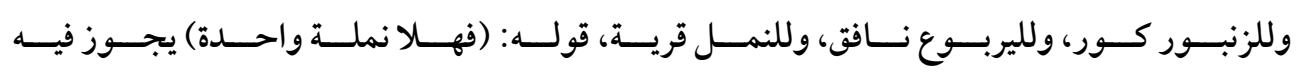

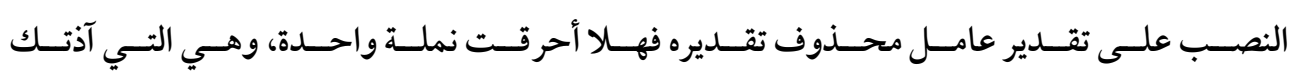
بخلاف غيرها فلم يصدر منها جناية .إ.هـ.

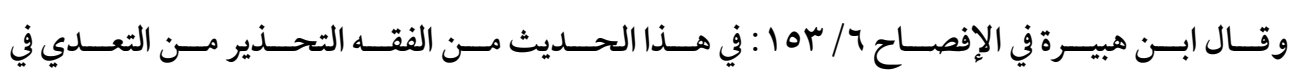

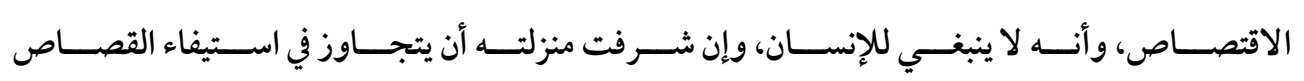

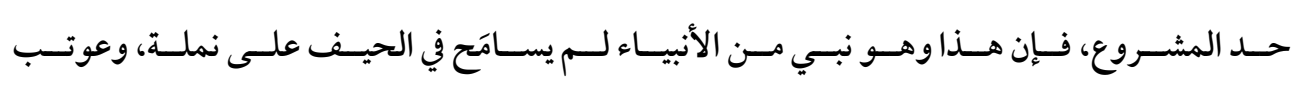
في ذلك. 


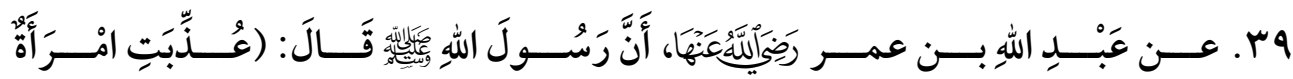

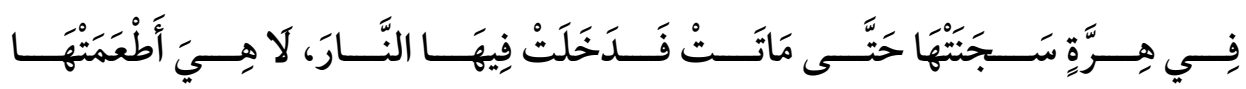

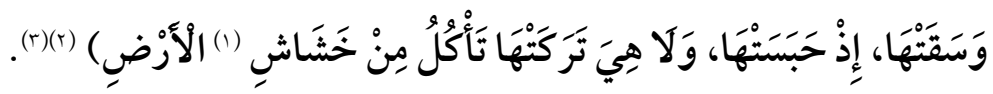

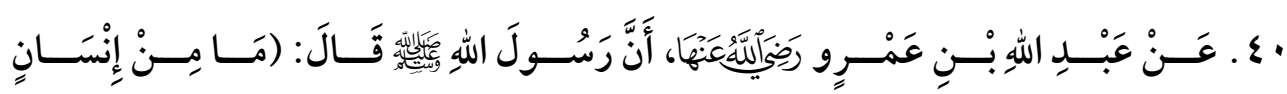

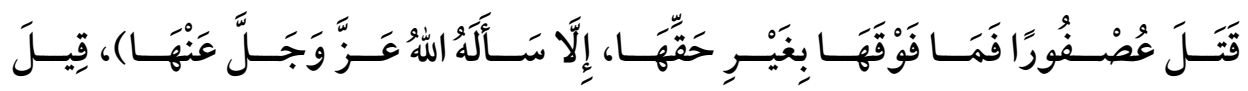

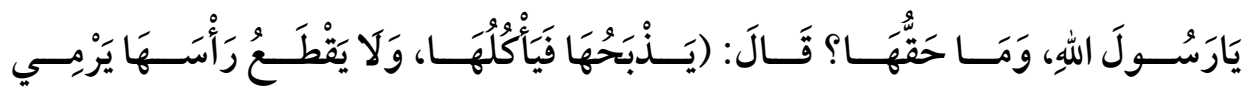

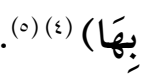

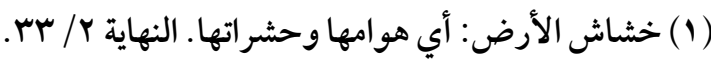

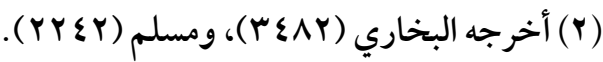

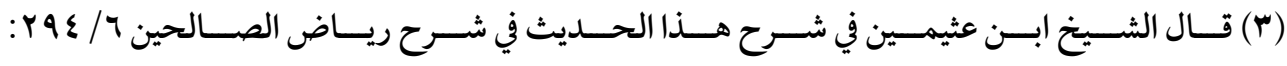

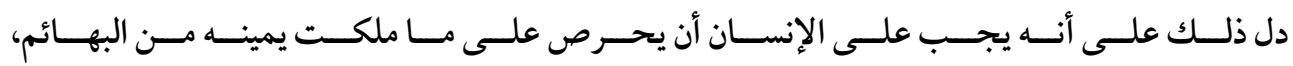

$$
\text { والآدميون أولى وأحرى لأنهم أحق بالإكرام. }
$$

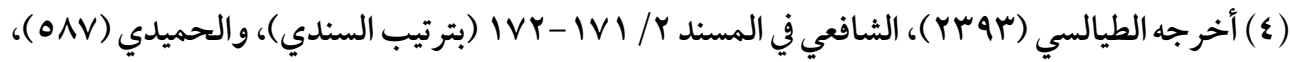

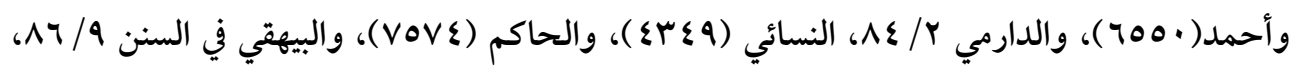

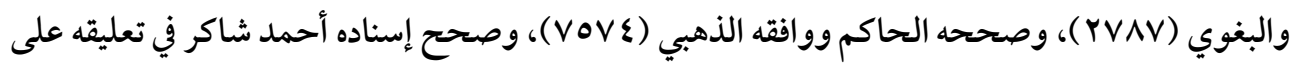

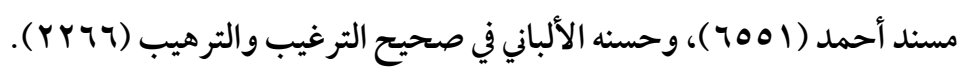
(•) قال ابن عبدالبر في الاستذكار \& / OV : قال أبو عمر وحرم رسول الله صلى الله عليه وسلم التمثيل

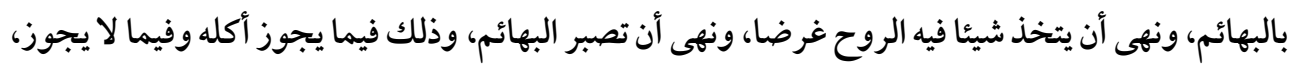
وإجماع العلماء المسلمين على ذلك، وقال صلى الله عليه وسلم: (من قتل عصفورا بغير حقه عذب به به يوم

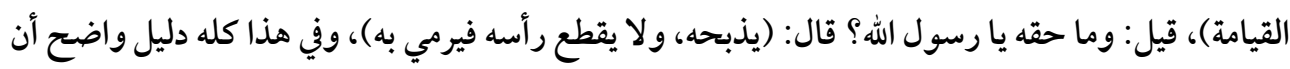

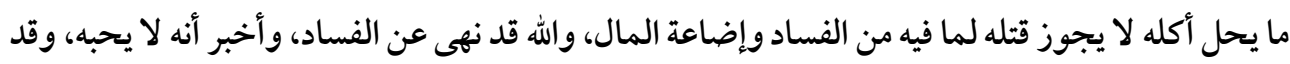




\section{من فتنة الدَجَّال سفكُ دماء الأبرياء}

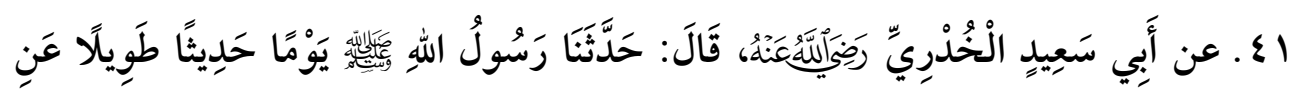

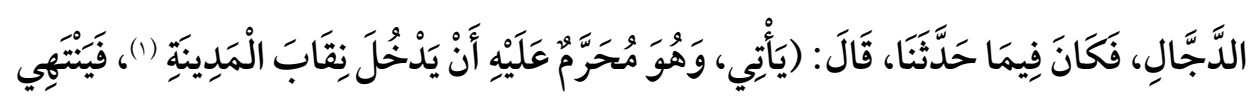

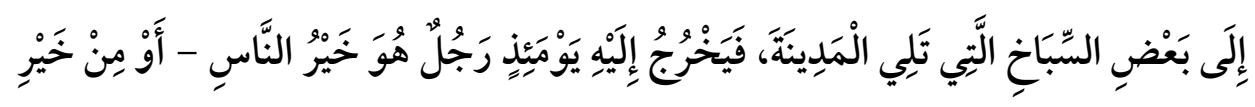

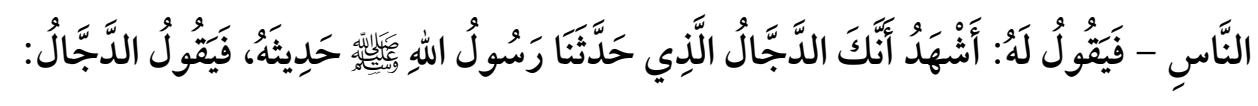

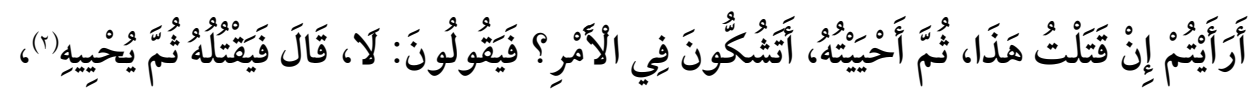

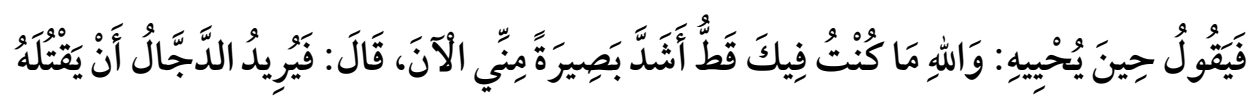

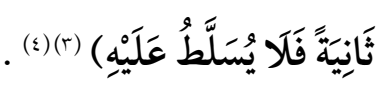

نهى عن إضاعة المال، وكل مقدور عليه ذكاته الذبح، وكل ممتنع من الصيد ذكاته الحديد حيث أدركت منه، مع سنة التسمية في ذلك.

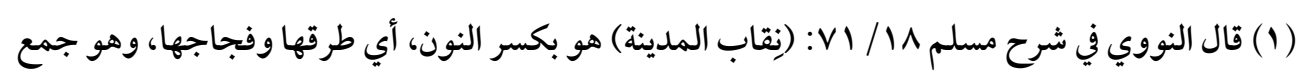

$$
\text { نقب، وهو الطريق بين جبلين. }
$$

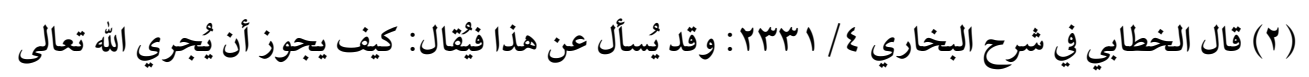

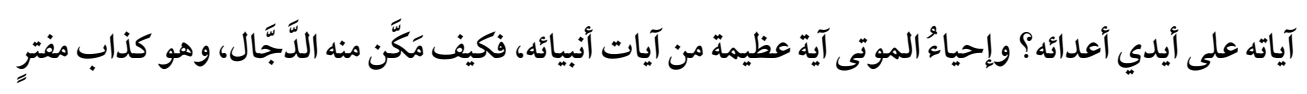

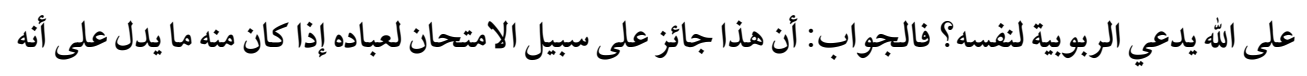

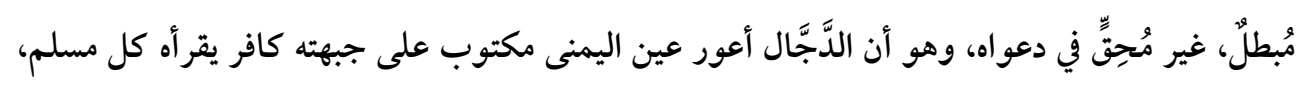

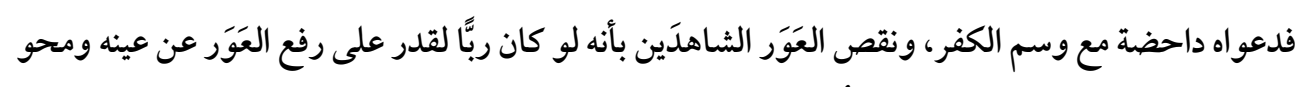

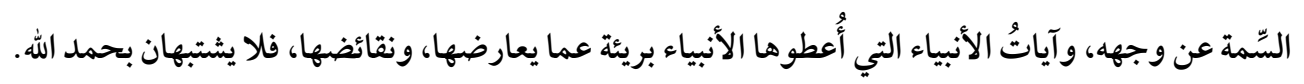

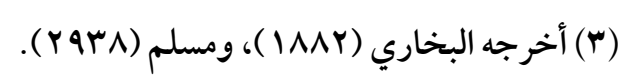

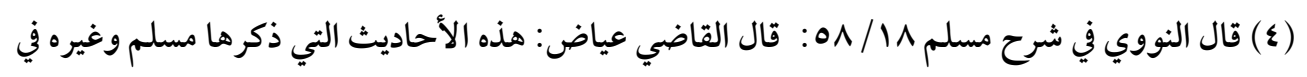

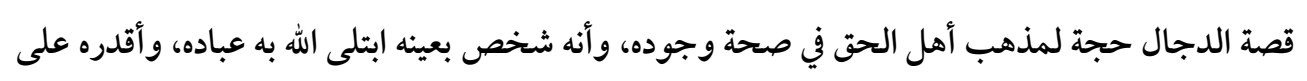

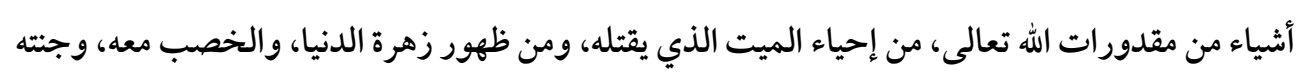




\section{تحستر القاتل على ما فعل من سفك الدماء}

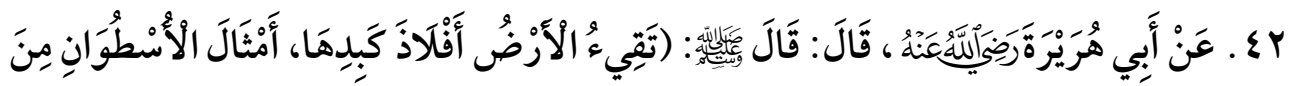

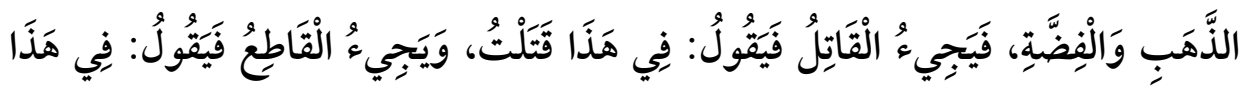

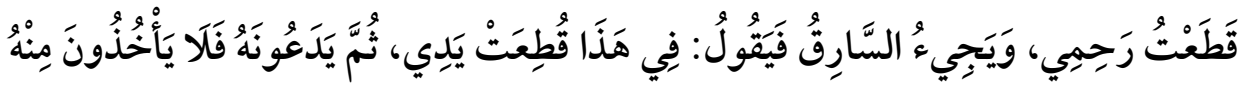
شَ) (1) (1) (1) (1)

وناره ونهريه، واتباع كنوز الأرض له، وأمره السماء أن تمطر فتمطر، والأرض أن تنبت فتنبت، فيقع كل ذلك بقدرة الله تعالى ومشيئه، ثم يعجزه الله تعالى بعد ذلك فلا يقدر على قتل ذلك الرجل ولى ولا غيره، ويبطل أمره، ويقتله عيسى صلى الله عليه وسلم، ويُثبّت الله الذين آمنوا، هذا مذهب أهل السنة وجميع المحدثين والفقهاء والنظار ، وهو يدعي الإلهية وهو في نفس دعواه مكذب لها بنقص صورته وعجزه عن إزالة العور الذي في عينيه، وعن إزالة الشاهد بكفره المكتوب بين عينيه، ولهذه الدلائل وغيرها لا يغتر به إلا رعاع من الناس لسد لهد الحاجة والفاقة رغبة في سد الرمق أو تقية وخوفا من أذاه؛ لأن فتتنه عظيمة جدا تدهش العقول وتحير الألباب، مع سرعة مروره في الأرض فلا يمكث بحيث يتأمل الضعفاء حاله، ولهذا حذرت الأنبياء صلوات الله وسلامه عليهم أجمعين من فتتته ونبهوا على نقصه ودلائل إبطاله. وأما أهل التوفيق فلا يغترون و لا يخدعون بما معهد

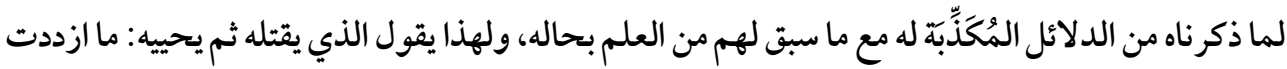
فيك إلا بصيرة. ا. هـ بتصرف يسير.

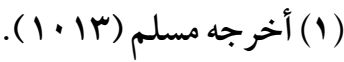

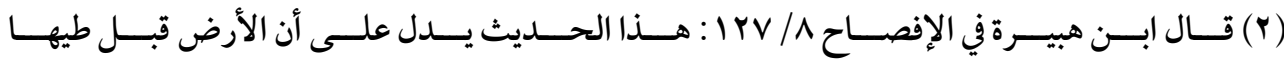

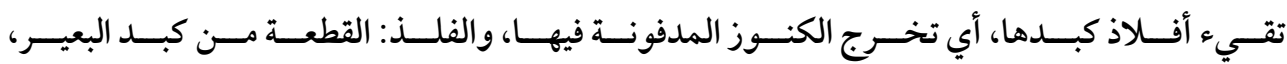

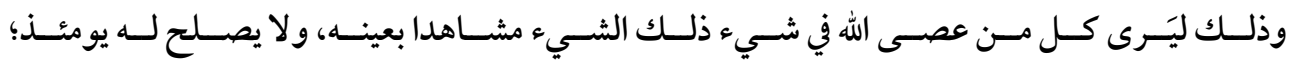

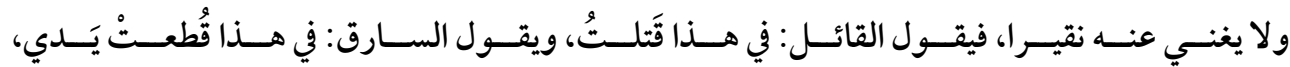

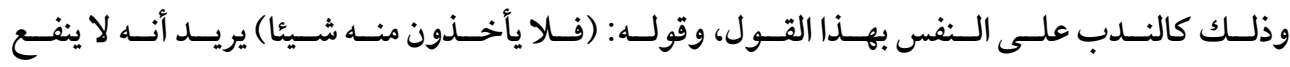
حينئذ؛ وقد رأوا عاقبة أخذه كيف كانت. 


\section{s. \\ الئهِ}

\section{البدائة بجرائم الدمائ يوم القيامة في القضائ بين الناس لئسئ}

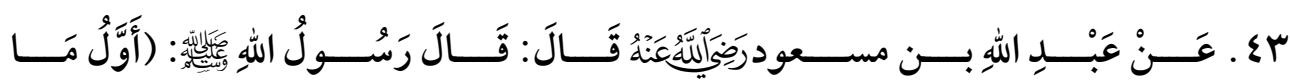

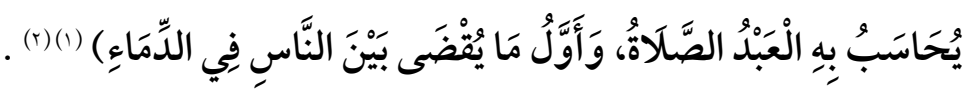

\section{مخاصمة القتتول لقاتله يوم القيامة عند الله، وزجر الله للقاتل قبل الدهاب به للنار}

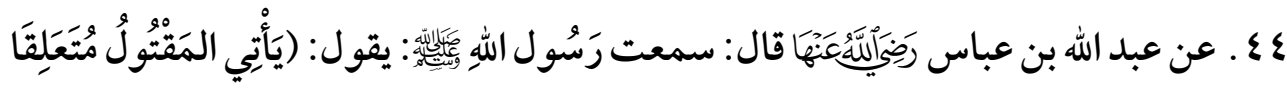

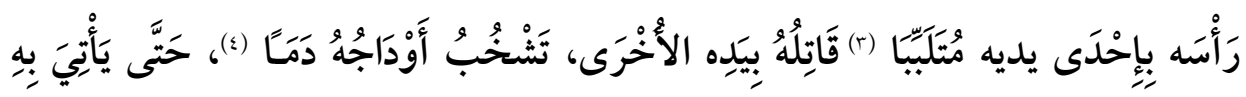

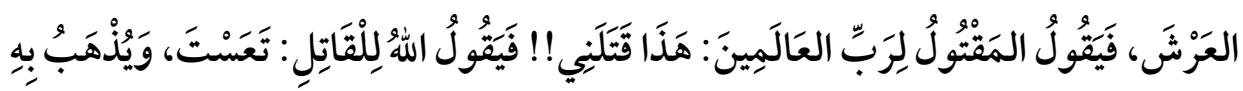
إِلَّ النَّارِ)(ْ)

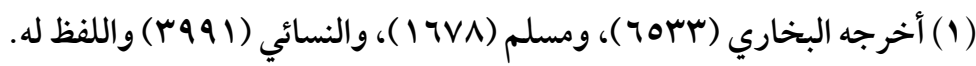

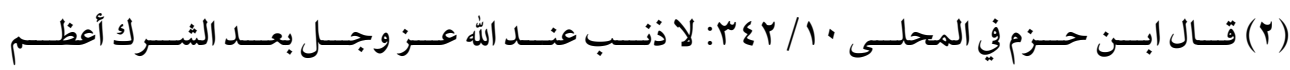

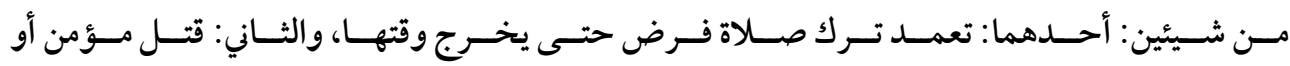

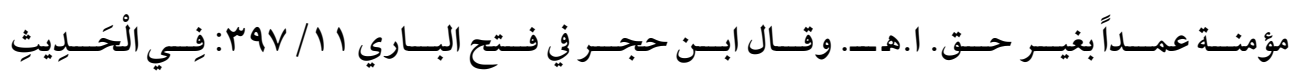

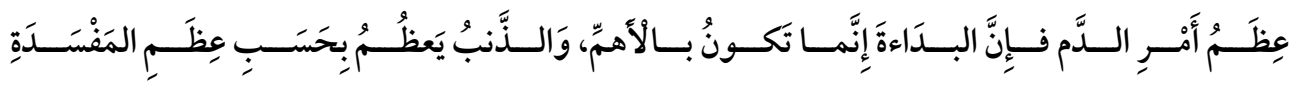

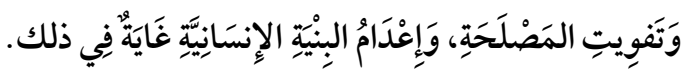
(r) لبيت الرجل ولبيته، إذا جعلت في عنقه ثوبا أو غيره وجررته به. وأخذت بتلبيب فلان، إذا جمعت عليه ثوبه الذي هو لابسه وقبضت عليه تجره. النهاية ؟ / سY Y . ( ) الشخب: السيلان، وأصل الشخب: ما يخرج من تحت يد الحالب عند كل غمزة وعصرة لضرع الشاة، و (أوداجه): هي ما أحاط بالعنق من العروق التي يقطعها الذابح، واحدها: وَدَج، بالتحريك، وقيل الودجان:

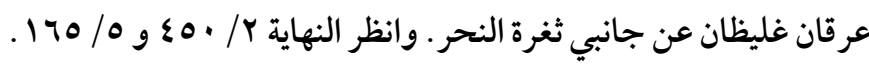

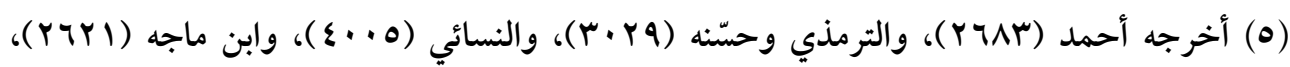
وصححه الألباني في الصحيحة ( r Y r ) . 
العدد السادس والثلاثون .

\section{की \\ عذاب القتلة في عرصات القيامة}

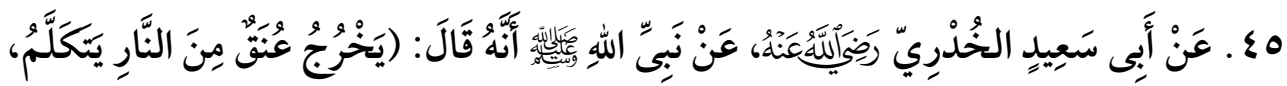

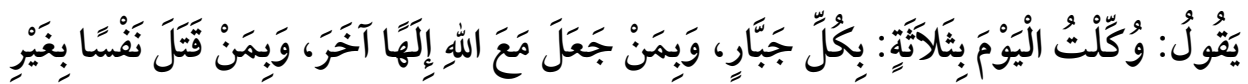

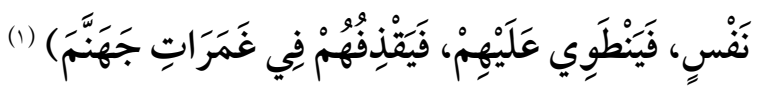

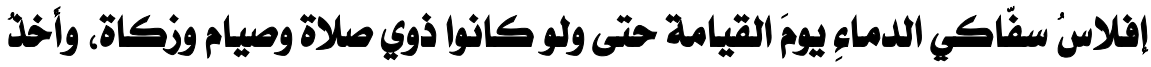
حسناتهم لغرمائهم ولمي

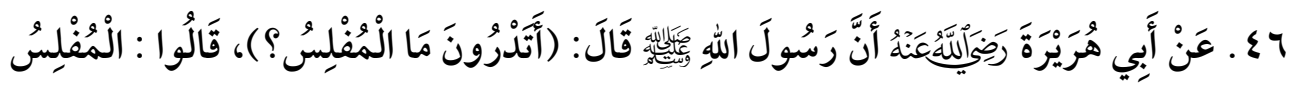

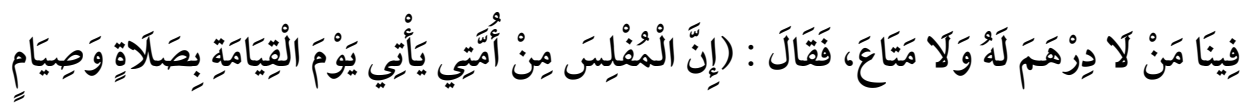

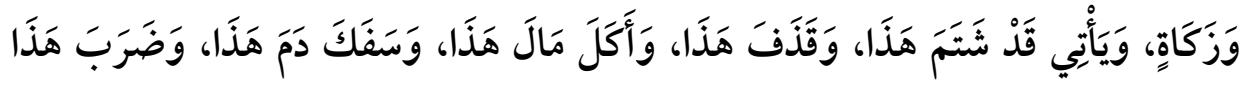

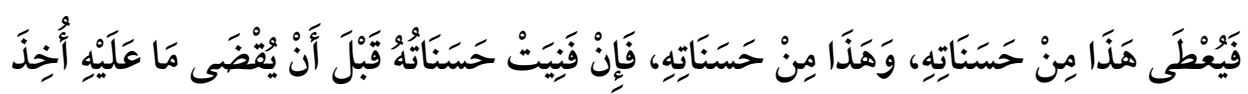

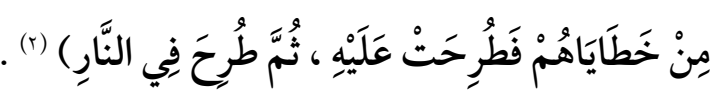

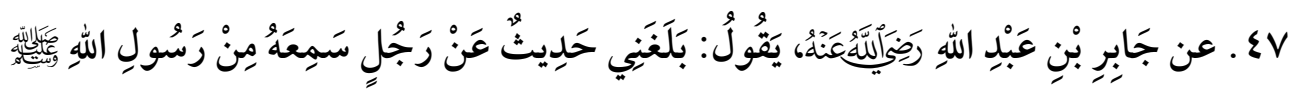

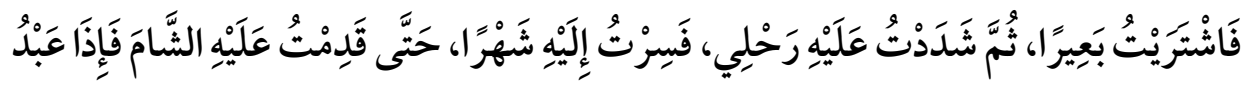

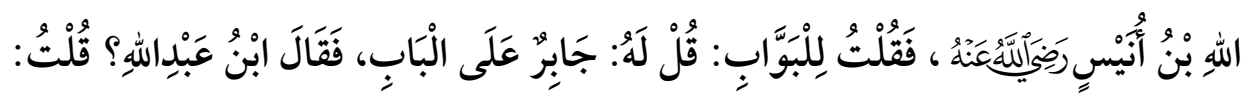

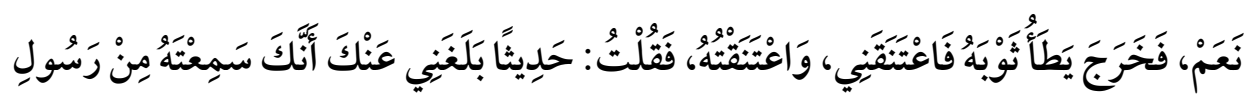

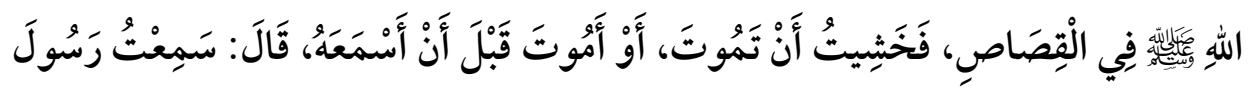

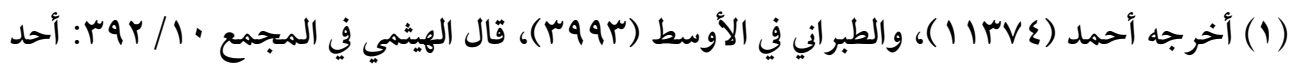

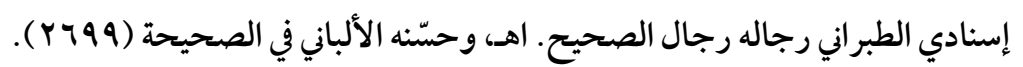

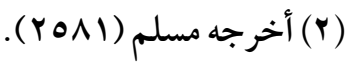

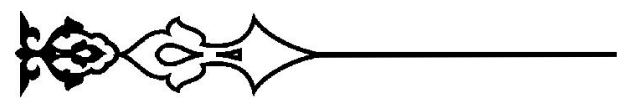




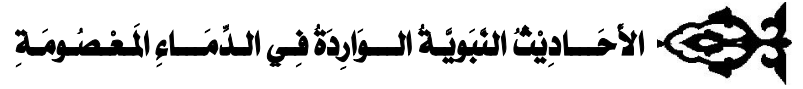

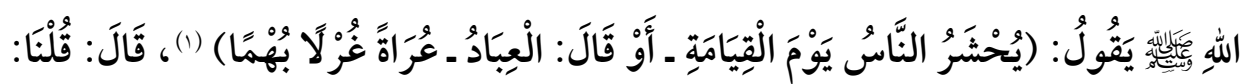

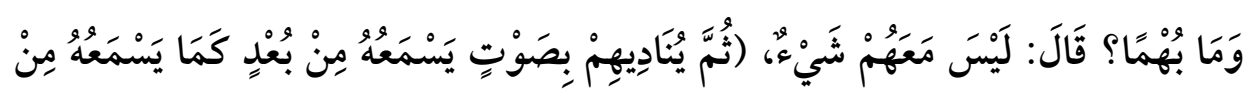

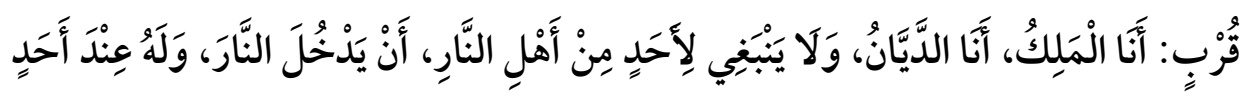

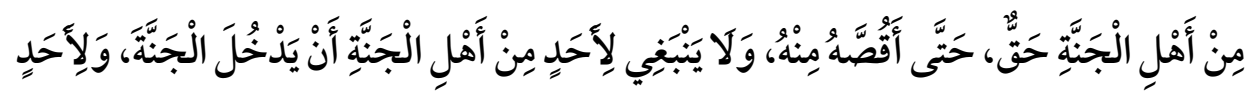

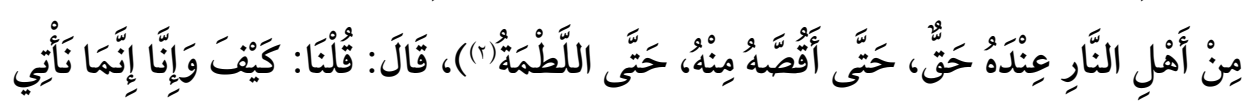

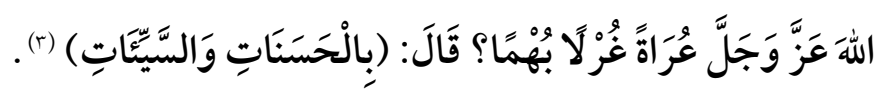

\section{النهي عن الاقتثتال، وذلك لتكثير الأمّة المحمدية}

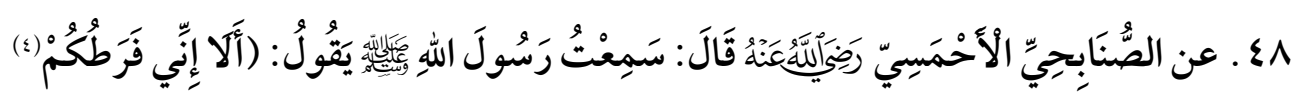

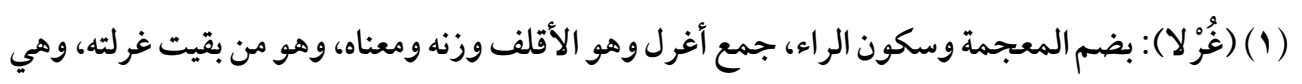

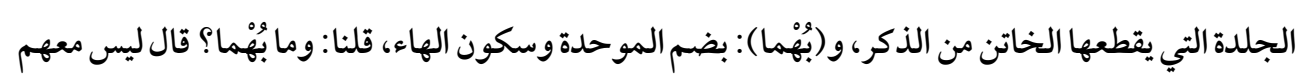

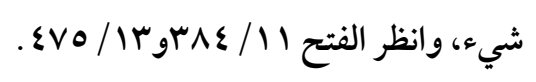

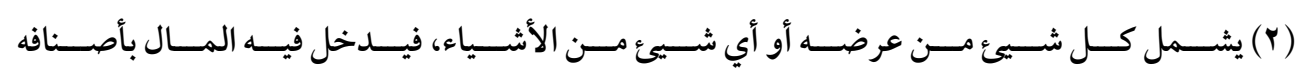

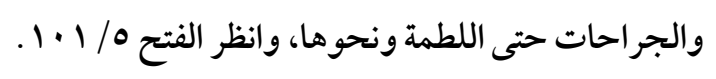

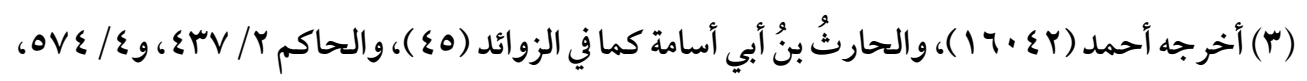

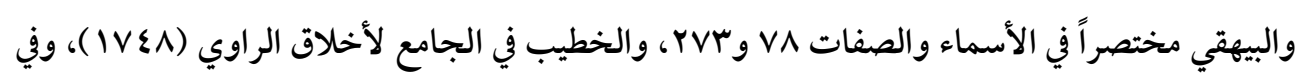

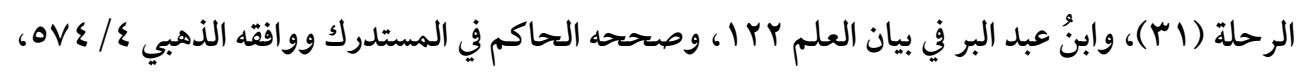

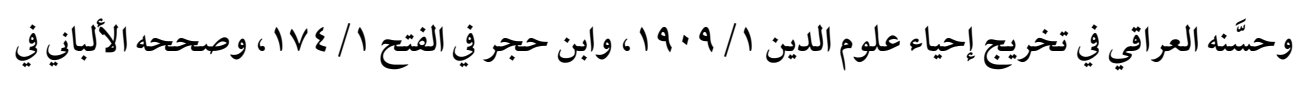

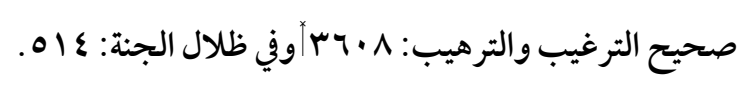

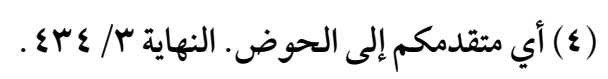

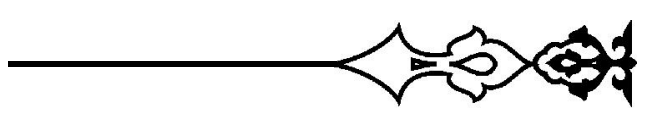




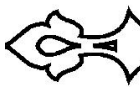

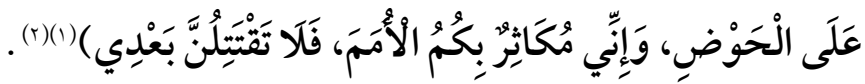

\section{الوعيد بالصدّ عن أبواب الجنة بسبب الوقوع في الدماء}

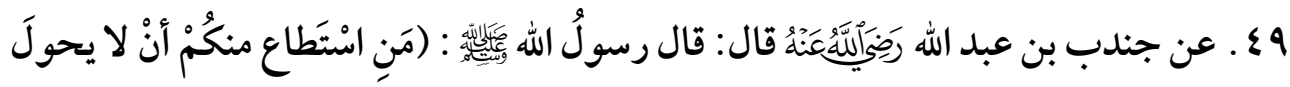

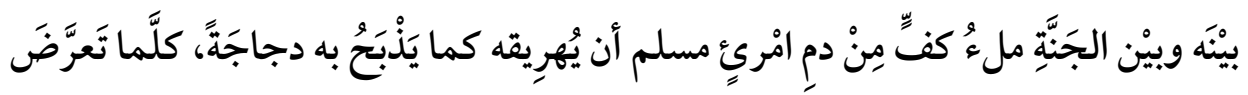

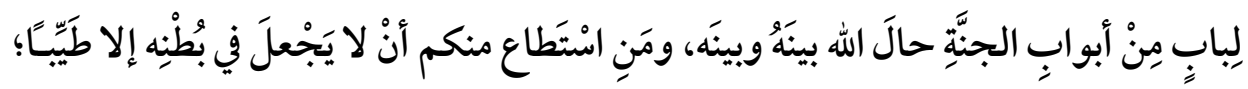

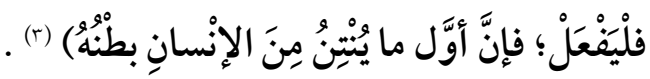

(1) ذكر المبارك فوري في تحفة الأحوذي / / اس في شرح الحديث: قوله: (مكاثر) : يعني إني أباهي بأكثرية

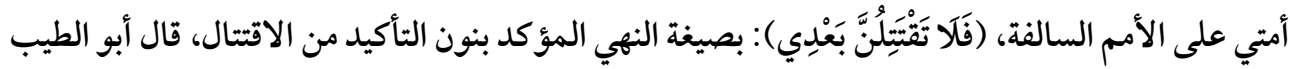

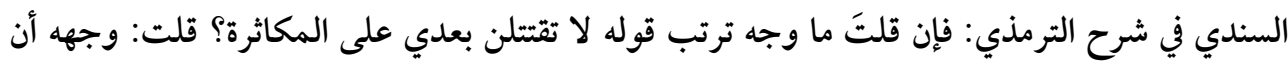

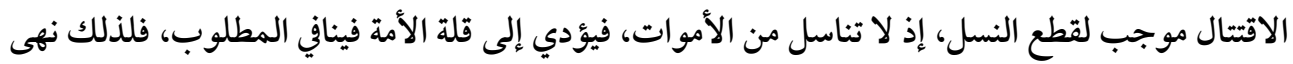

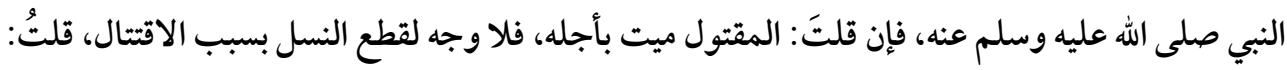
إما أن يقال إن الإقدام على الاقتتال مفض بقطع النسل، فالنسل باعتبار فعلهم الاختياري، أو يقال: يكون لهم

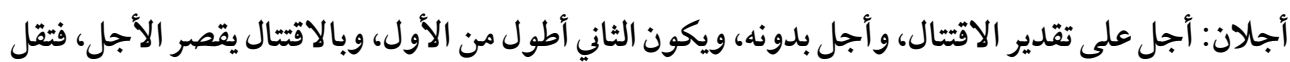
الأمة، وهذا يرد عليه أن عند الله لا يكون إلا أجل واحد. انتهى كلام أبي الطيب.

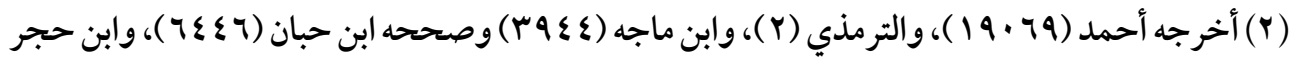

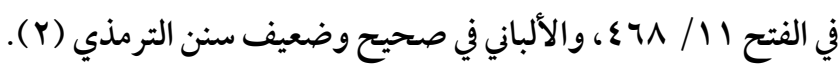

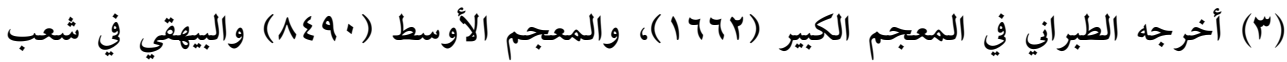

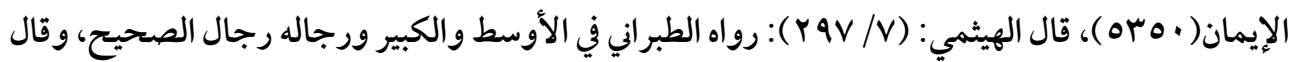

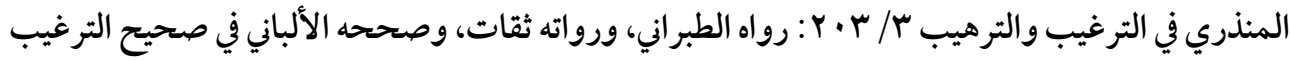

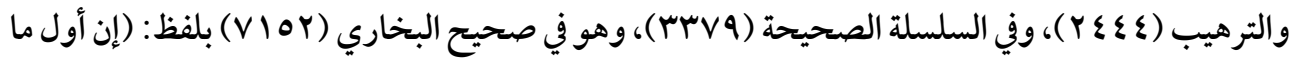
ينتن من الإنسان بطنه، فمن استطاع أن لا يأكل إلا طيبا فليفعل، ومن استطاع أن لا يحال بينه وبين الجنة بمل كفه من دم أهر اقه فليفعل). 


\section{النَار عقوبة من عزم على قتل أخيه المسلم}

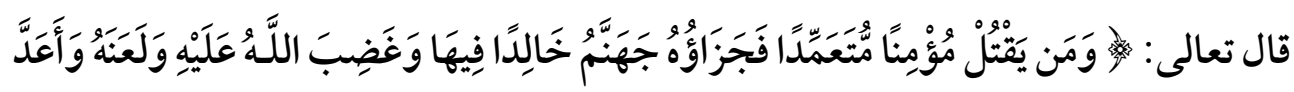
لَهُ عَذَابًا عَظِيمًا

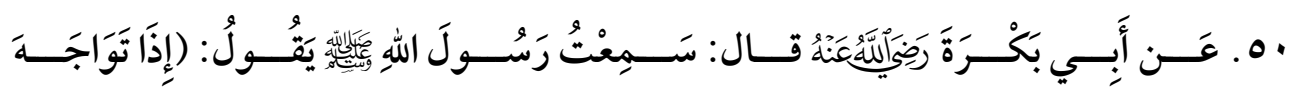

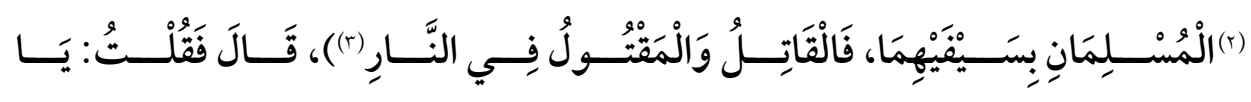

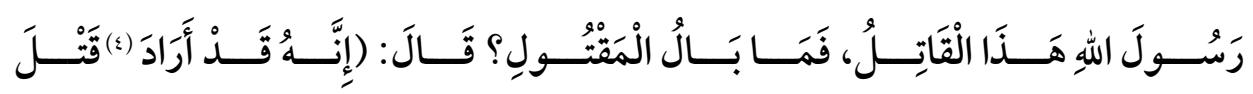

$$
\text { صَاحِبِِ( ) }
$$

الحذر من الاعتدائ بالقتل على من كان في عهد الله وذمته

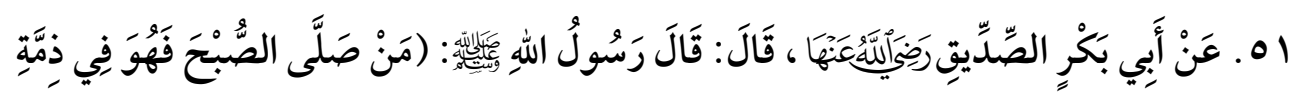

(Y) قال النووي في شرح مسلم 1/ / / 11 : معنى تواجها: ضربَ كل واحد وجه صاحبه، أي ذاته وجملته.

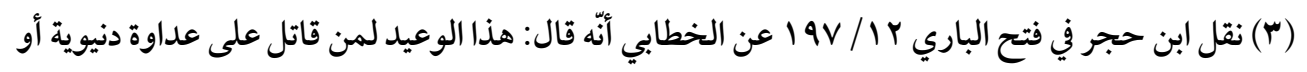

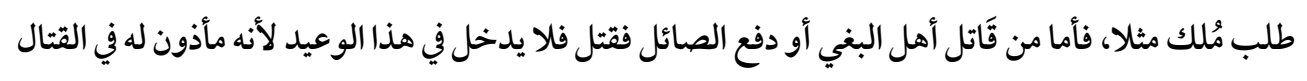

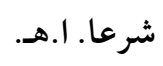

(ع) قال النووي في شرح مسلم 1/ / 1 1 : فيه دلالة للمذهب الصحيح الذي عليه الجمهور أن من نوى

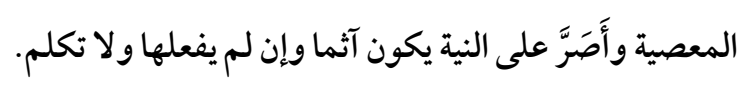

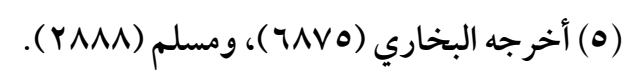




\section{ชิ}

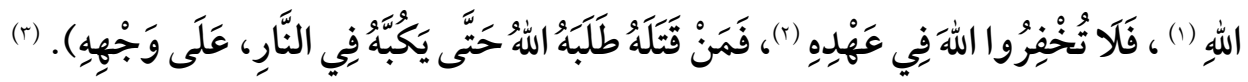

\section{باب التوبة مفتوح في الدنيا}

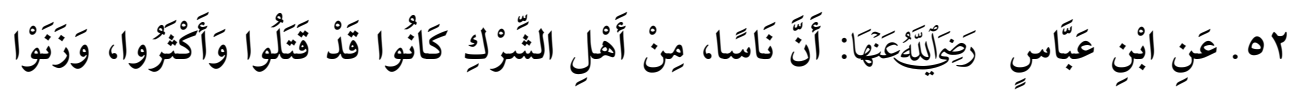

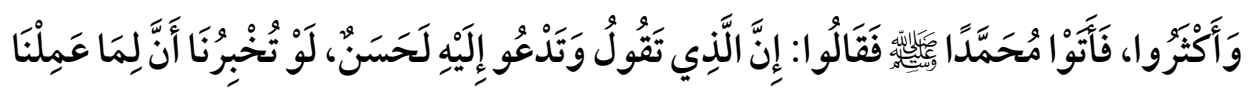

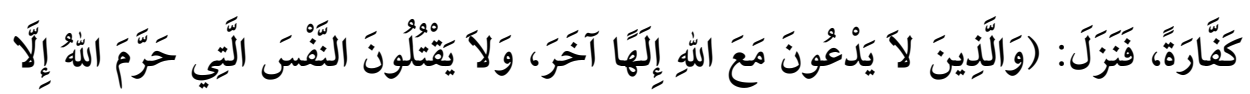

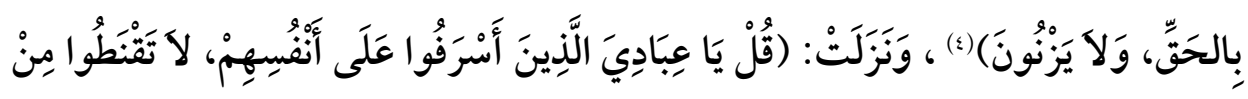

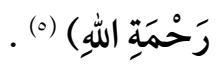

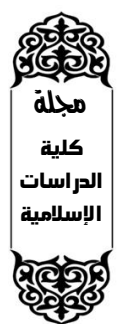

(1) قال الشيخ صالح آل الشيخ في التمهيد لشرح كتاب التوحيد 79ه : الذمة بمعنى العهد، وذمة الله يعني: عهد الله.

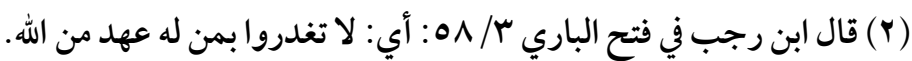

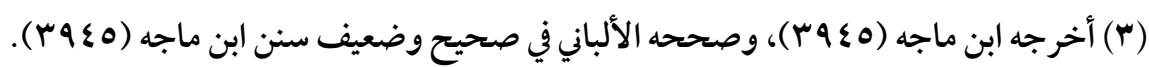
( ) سورة الفرقان آية \؟.

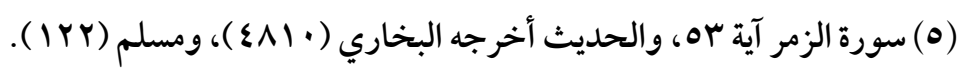




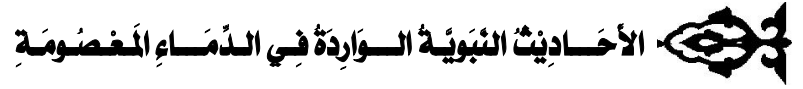

\section{خاتثـــــة}

الحمد لله، والصلاة والسلام على رسول الله، أمّا بعد:

فقد سبق في المقدمة أن حرمة الدماء المعصومة بلغت فيه الأحاديث حدّ التواتر

المعنوي، المفيد للعلم اليقيني، حيث تظافرت النصوص الشرعية الصحيحة، الصريحة من

الكتاب الكريم والسيّة النبويّة التي تحذر من القتل بغير حق تحذيرًا شديدًا، وتبين سوء عاقبته،

وعظم عقوبة، وأنّه لا يجوز بأيّ حال ولا تحت أي ذريعة قتل من عصم الشرع دمه من المسلمين والكافرين غير المحاربين من المعاهدين والذميين والمستأمنين بغير حق، ومن فعل ذلك فهو متوعد بالنكال الشديد، والعذاب الأليم، ومرتكب لجريمة من أكبر الكبائر، كما أنّ الإسلام وهو دين الفطرة قد جاء مؤكدا على المحافظة على الضرورات الخمس التي منها: النفس. وقد تضمنت هذه النصوص الصحيحة التي أورتها هنا: تعظيم إثم أوّل من سنّ القتل، وتوعد قاتل المؤمن بعدم المغفرة وعدم قبول عمله ووقوعه في الهلاك، وأنّ نفس المؤمن أعظم حرمة عند الله من الكعبة المعظّمة، وأنّ القتل من إضلال الشيطان، ومن أحبّ الأعمال إليه، وأنّ قتال المسلم كفر، وقد ورد نفي الإيمان عن القاتل، وأنّ زوال الدنيا أهون على الله من قتل مسلم، وفيها أيضا: التحذيرُ من حمل السلاح على المسلمين، وفي أماكن تجمعاتهم، واجتنابُ ترويعهم به حتى ولو كان مزحا، كذلك ورد مايدلّ على الترهيب من رمي المسلمين بمقذوفات أو متفجرات أو أي سلاح، وسوء عاقبة الخروج من طاعة ولي الأمر، وجاهلية القتال تحت غير رايته الشرعية، والزجر الشديد عن قتل من قال لا إله إلا الله، وحمل الثّاس على الظاهر، والله يتولى سرائرهم، وأنّ الإيمان يمنع أهله من الاغتيالات والغدر، وأنّ من أشراط الساعة كثرة القتل بغير حق، والوعيد الشديد من تفجير الشخص نفسه أو قتلها بأي

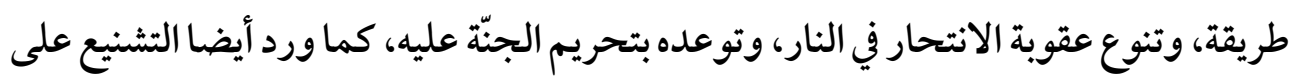

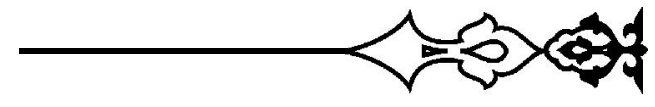




\section{की}

قتل الرجل لقرابته في آخر الزمان، والنهي عن قتل النساء والأطفال، كما ورد أيضا منع النبي

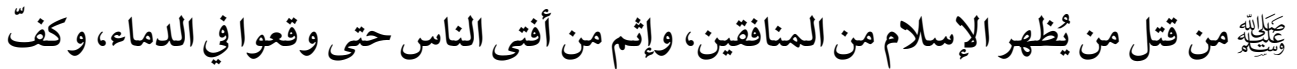

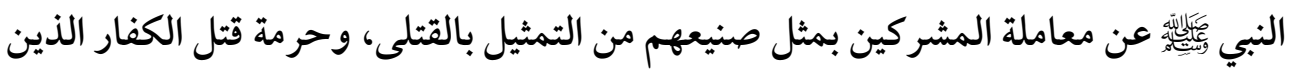
أذن لهم ولي الأمر في دخول البلاد من المعاهدين والمستأمنين، وشناعة الغدر بهم.

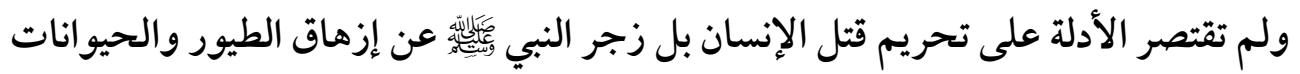

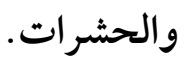

وأنّ من فتنة الدَّجَّال سفكُ دماء الأبرياء، وتحسّر القاتل يوم القيام على مافعل من سفك

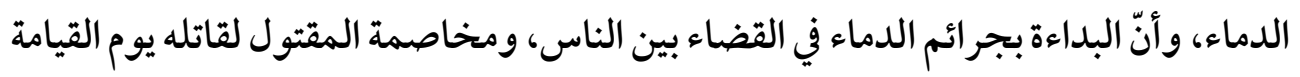
عند الله، وزجر الله للقاتل قبل الذهاب به للنار، كما ورد أيضا عذاب القتلة في عرصات

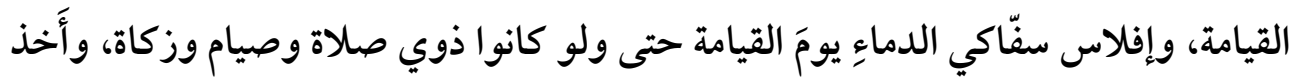

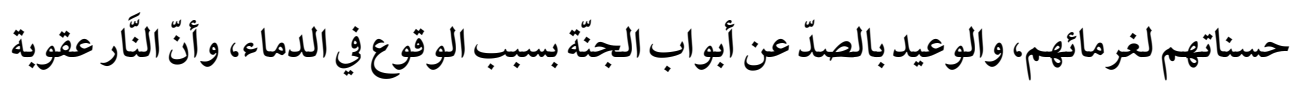
من صدر منه عزم على قتل أخيه المسلم، والحذر من الاعتداء بالقتل على من كان في عهد الله وذذمّنه.

ثمّ ختمت بأن باب التوبة مفتوح في الدنيا لمن تلطخت يده بسفك الدماء المعصومة إذاصدق

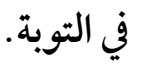
وصلى الله وسلّم على سيدنا ونبينا محمد، وعلى آله وصحابته

تم بِحسمْمِدِ الله

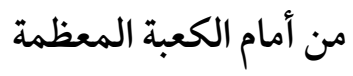




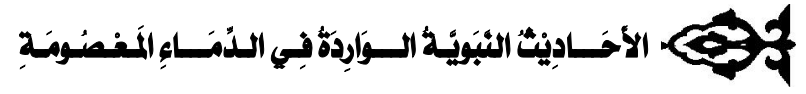

\section{المصادروالئراجع}

ـ أحكام أهل الذمة، لمحمد بن أبي بكر ابن قيم الجوزية، تحقيق: يوسف بن أحمد البكري

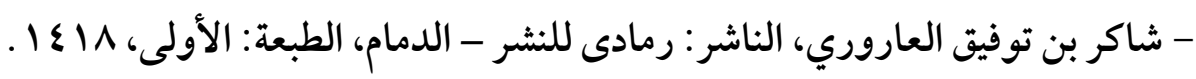
- إرشاد الساري لشرح صحيح البخاري، لأحمد بن محمد القسطلاني، الناشر: المطبعة

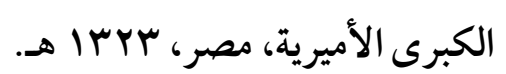

ـ أعلام الحديث (شرح صحيح البخاري)، لأبي سليمان حمد بن محمد الخطابي، تحقيق: د.محمد بن سعدبن عبدالرحمن آل سعود، الناشر :جامعة أم القرى، الطبعة:الأولى، 9 • ع أهـ الهـ ــ أعلام السنة المنشورة لاعتقاد الطائفة الناجية المنصورة، لحافظ بن أحمد الحكمي، الناشر: وزارة الشؤون الإسلامية والأوقاف والدعوة والإرشاد - المملكة العربية السعودية، الطبعة:

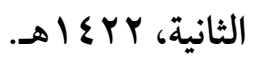

- إعلام الموقعين عن رب العالمين، لمحمد بن أبي بكر ابن قيم الجوزية، تحقيق: مشهور

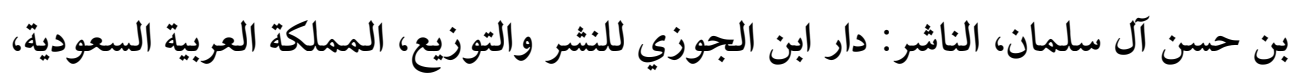

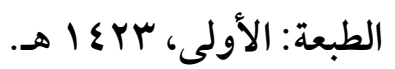

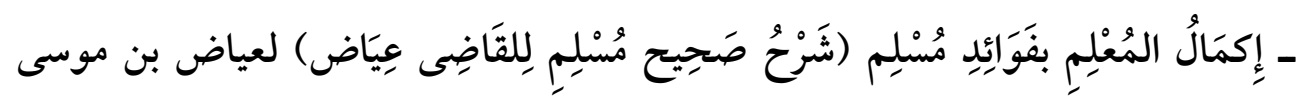

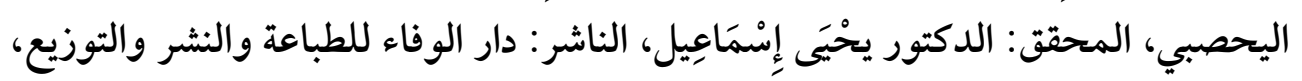

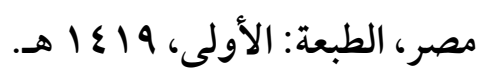

ـ الأحاديث المختارة أو المستخرج من الأحاديث المختارة مما لم يخرجه البخاري ومسلم في صحيحيهما، ضياء الدين المقدسي، دراسة وتحقيق: الدكتور عبد الملك بن عبد الله بن دهيش، الناشر : دار خضر للطباعة والنشر والتوزيع، بيروت، الطبعة: الثالثة، · ؟ ع أهـ. ـ الإحسان في تقريب صحيح ابن حبان، لمحمد بن حبان البُستي، ترتيب: الأمير علاء الدين

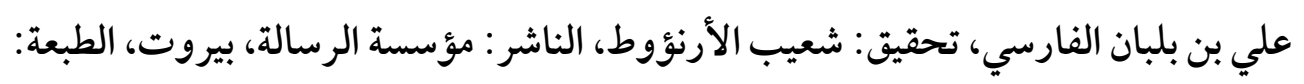

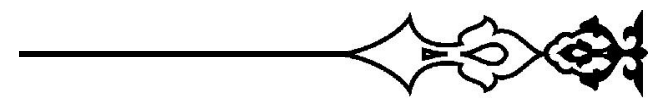


ـ الأدب المفرد، لمحمد بن إسماعيل البخاري، تحقيق: محمد فؤاد عبد الباقي، الناشر : دار

$$
\text { البشائر الإسلامية - بيروت. }
$$

ـ الاستذكار، لأبي عمر يوسف ابن عبد البر، تحقيق: سالم محمد عطا، محمد علي معوض،

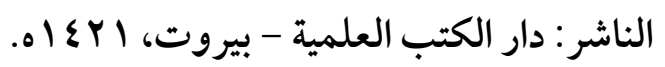

ـ الأسماء والصفات، لأحمد بن الحسين، أبو بكر البيهقي، تحقيق: عبد الله بن محمد

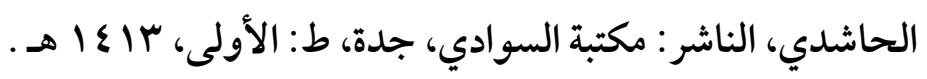

ـ الإفصاح عن معاني الصحاح، ليحيى ابن هبيرة، المحقق: فؤاد عبد المنعم أحمد، الناشر:

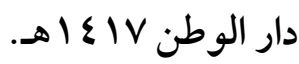

ـ الإيمان، لأبي العباس أحمد بن عبد الحليم ابن تيمية، المحقق: محمد ناصر الدين الألباني،

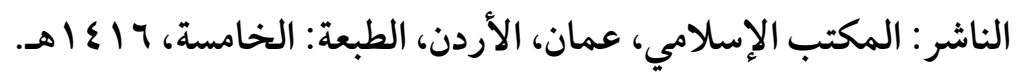
ـ التاريخ الكبير، لمحمد بن إسماعيل البخاري، الطبعة: دائرة المعارف العثمانية، حيدر آباد

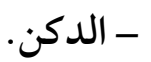
ـالتحرير والتنوير، لمحمد الطاهر بن عاشور التونسي، الناشر : الدار التونسية للنشر - تونس،

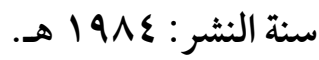
ـ التلخيص الحبير في تخريج أحاديث الر افعي الكبير، لأبي الفضل أحمد بن علي بن محمد بن أحمد بن حجر العسقلاني، تحقيق: أبو عاصم حسن بن عباس بن قطب، الناشر : مؤسسة بـ بن قرطبة بمصر، الطبعة: الأولى، 7 اء أهـ ـ التمهيد لشرح كتاب التوحيد، دروس ألقاها الشيخ صالح بن عبد العزيز آل الشيخ، ثم

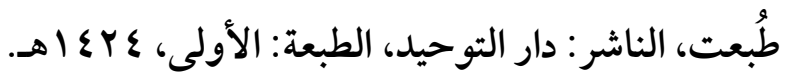


ـ التمهيد لما في الموطأ من المعاني والأسانيد، لأبي عمر يوسف ابن عبد البر، تحقيق:

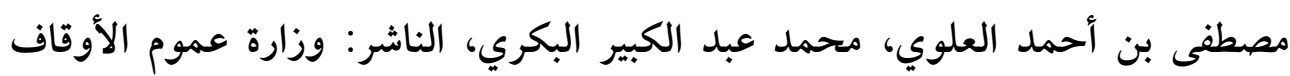

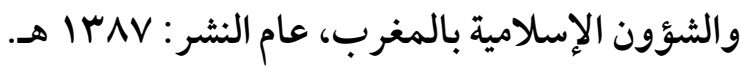

ـ التنوير شرح الجامع الصغير، لمحمد بن إسماعيل الصنعاني، المعروف بالأمير، تحقيق: د.

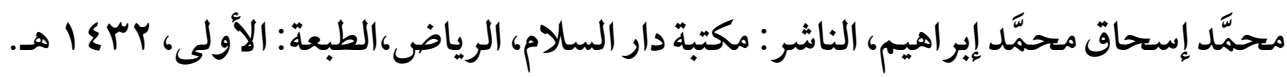
ـ الجامع المسند الصحيح المختصر من أمور رسول الله صلى الله عليه وسلم وسننه وأيامه. (صحيح البخاري)، لمحمد بن إسماعيل البخاري، الناشر: دار طوق النجاة (مصورة عن

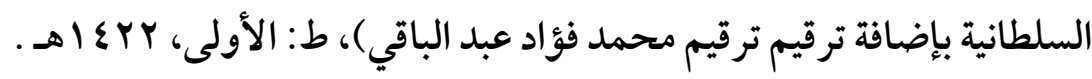
ـ الجامع لأخلاق الراوي وآداب السامع، لأبي بكر أحمد بن علي بن ثابت الخطيب

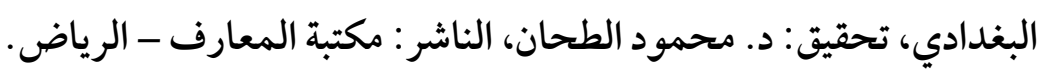

ـ الجواب الكافي لمن سأل عن الدواء الشافي، أو الداء والدواء، لمحمد بن أبي بكر ابن قيم

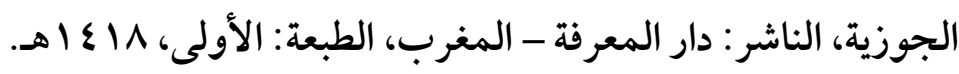

ـالرحلة في طلب الحديث، لأبي بكر أحمد بن علي بن ثابت الخطيب البغدادي، تحقيق: نور

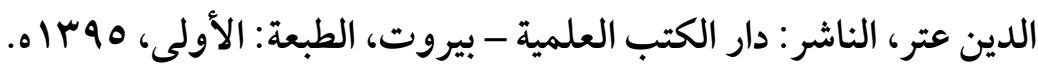
ـ الرَّوضُ البَّسَام بتَرتيْبِ وَتخْرِيج فَوَائِدِ تَمَّام، لأبي سليمان جاسم الفهيد الدوسري، الناشر:

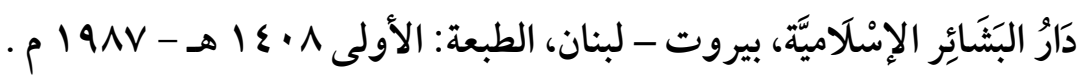

ـ الروض الداني (المعجم الصغير )، لسليمان بن أحمد أبي القاسم الطبراني، تحقيق: محمد شكور محمود الحاج أمرير، الناشر : المكتب الإسلامي، دار عمار - بيروت، عمان ، الطبعة:

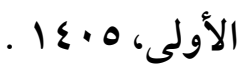

ـ السنن الصغرى (المجتبى من السنن)، لأبي عبد الرحمن أحمد بن شعيب النسائي، تحقيق: 
عبد الفتاح أبو غدة، الناشر : مكتب المطبوعات الإسلامية - حلب، ط: الثانية، 7 ـ ع ـ ـ . ـ السنن الكبرى لإبي بكر البيهقي مكتبة دار الباز تحقيق محمد عطا. ـ السنن الكبرى لأبي عبد الرحمن أحمد بن شعيب النسائي، تحقيق: حسن عبد المنعم

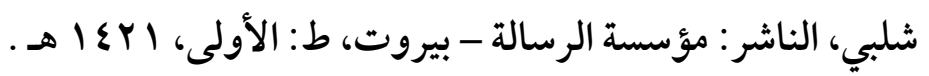

ـ الصحاح تاج اللغة وصحاح العربية، لأبي نصر إسماعيل الجوهري، تحقيق: أحمد عبد الغفور عطار، الناشر : دار العلم للملايين - بيروت، الطبعة: الرابعة V • ع أهـ.

ـ الطبقات الكبرى لمحمد بن سعد، تحقيق: محمد عبد القادر عطا، الناشر: دار الكتب

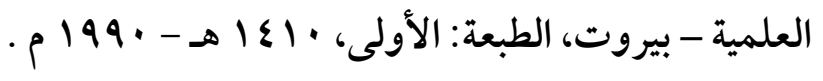

ـ القول المفيد على كتاب التوحيد، لمحمد بن صالح العثيمين، الناشر : دار ابن الجوزي،

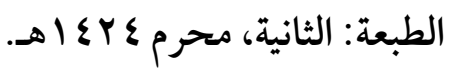

ـ المحكم و المحيط الأعظم، لأبي الحسن علي بن إسماعيل بن سيده، المحقق: عبد الحميد

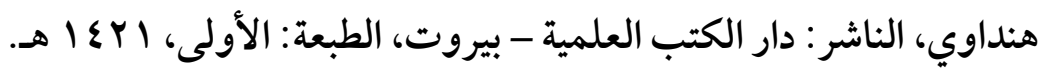
ـ المحلى بالآثار، لأبي محمد علي ابن حزم الأندلسي، الناشر: دار الفكر - بيروت. ـ المستدرك على الصحيحين، لأبي عبد الله الحاكم النيسابوري، تحقيق: مصطفى عبد القادر

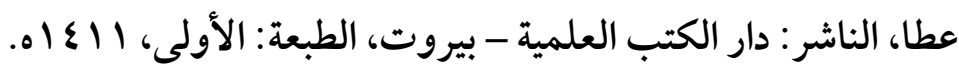
ـ المسند للإمام أحمد بن حنبل الشيباني موسوعة الرسالة الطبعة الثانية تحقيق شعيب الأرناؤوط ورفاقه.

ـ المصنف، لعبد الرزاق الصنعاني، تحقيق حبيب الرحمن الأعظمي، المجلس العلمي، الهند. ـ المصنف لابن أبي شبية شركة دار القبلة ومؤسسة علوم القرآن، الطبعة الأولى ع \& اهـ 
ـ المعالم الأثيرة في السنة والسيرة، محمد شُرَّاب، الناشر : دار القلم، الدار الشامية، بيروت،

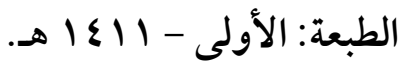

ـ المعجم الأوسط للامام الطبراني دار الحرمينه إع ا تحقيق طارق عوض الله. ـ المعجم الصغير للامام الطبراني المكتب الإسلامي ودار عمار الطبعة الأولى تحقيق محمد شكور. ـ المعجم الكبير للامام الطبراني مكتبة ابن تيميه القاهره تحقيق حمدي السلفي ـ المغني عن حمل الأسفار في الأسفار، في تخريج ما في الإحياء من الأخبار (مطبوع بهامش

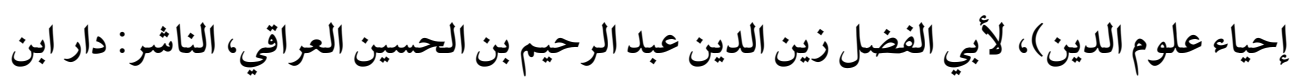

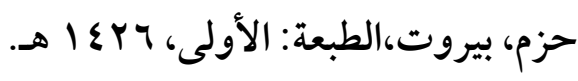

ـ المنتقى من السنن المسندة، لأبي محمد عبد الله بن علي بن الجارود النيسابوري، المحقق:

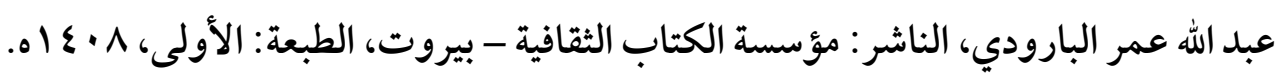
ـ النهاية في غريب الحديث والأثر، ابن الأثير، الناشر: المكتبة العلمية - بيروت، 99 با هـ ـ 19V9 ام ، تحقيق: طاهر أحمد الزاوى - محمود محمد الطناحي .

- بغية الباحث عن زوائد مسند الحارث لأبي محمد الحارث المعروف بابن أبي أسامة،

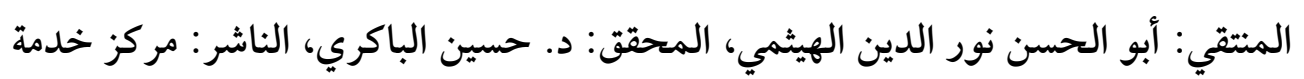

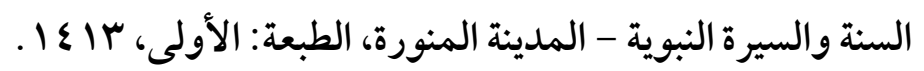

ـ تاريخ أصبهان (أخبار أصبهان)، لأبي نعيم أحمد بن عبد الله الأصبهاني، المحقق: سيد

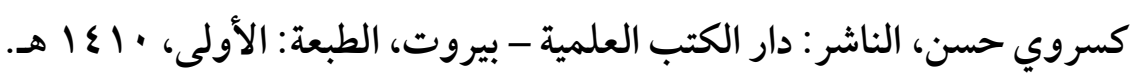
ـ تحفة الأحوذي شرح جامع الترمذي، لأبي العلا محمد عبد الرحمن بن عبد الرحيم 
المبار كفوريي، الناشر : دار الكتب العلمية بيروت.

ـ تفسير القرآن العظيم (ابن كثير)، لإسماعيل بن عمر ابن كثير، المحقق: محمد حسين شمس الدين، الناشر: دار الكتب العلمية، منشورات محمد علي بيضون - بيروت، الطبعة:

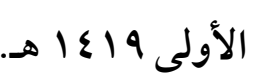

ـ تفسير القرطبي (الجامع لأحكام القرآن)، لمحمد بن أحمد القرطبي، تحقيق: أحمد

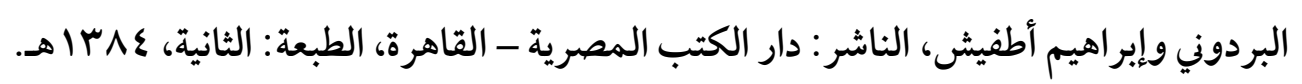
ـ تيسير الكريم الرحمن في تفسير كلام المنان، لعبد الرحمن بن ناصر السعدي، تحقيق: عبد

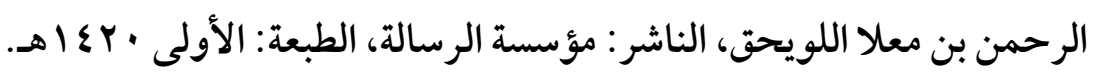
ـ جامع بيان العلم وفضله، يوسف ابن عبدالبر النمري، تحقيق: أبو الأشبال الزهيري، دار ابن

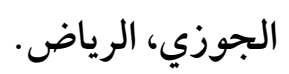
ـ خلق أفعال العباد، لمحمد بن إسماعيل البخاري، الناشر : دار المعارف، الرياض. ـ سلسلة الأحاديث الصحيحة وشيء من فقهها وفوائدها، لناصر الدين الألباني، الناشر : مكتبة المعارف للنشر والتوزيع، الرياض. ـ سنن ابن ماجه، لأبي عبد الله محمد بن يزيد القزويني، وماجة اسم أبيه يزيد، تحقيق: محمد فؤاد عبدالباقي، الناشر : دار إحياء الكتب العربية - فيصل عيسى البابي الحلبي . ــن سن أبي داود، لأبي داود سليمان بن الأشعث السِّجِتْتاني ، تحقيق: محمد محيي الدين عبد

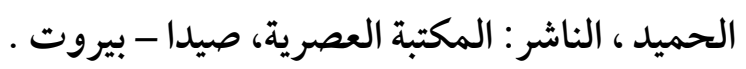
ـ سنن أبي داود، لأبي داود سليمان السِّحِنْتاني، المحقق: شعَيب الأرنؤوط - محَمَّد كامِل قره بللي، الناشر: دار الرسالة العالمية، · بـ إئ هـ. - سنن الترمذي، لمحمد بن عيسى بن سَوْرة الترمذي،تحقيق: أحمد محمد شاكر

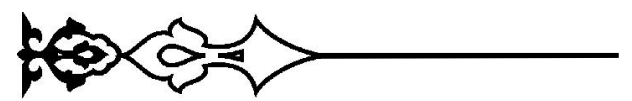
I $\mathrm{H}$ 
وآخرين،الناشر : شركةالبابي الحلبي - مصر، ط: الثانية، ه9 سا هـ

ـ سنن الدارقطني للإمام الدار قطني مؤسسة الرساله الطبعه الأولى تحقيق شعيب الأرناؤوط وجماعة.

ـ سنن الدارمي لإبي محمد الدارمي دار الكتاب العربي الطبعة الأولى تحقيق فواز زمرلي

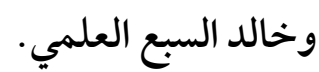

ـ شرح رياض الصالحين، لمحمد بن صالح العثيمين، الناشر: دار الوطن للنشر، الرياض،

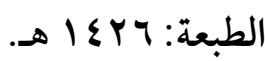

ـ شرح صحيح البخارى لابن بطال، لابن بطال أبو الحسن علي بن خلف، تحقيق: أبو تميم

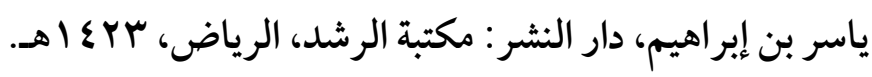

ـ صحيح ابن حبان بترتيب ابن بلبان، لمحمد بن حبان البُستي، تحقيق: شعيب الأرنؤوط

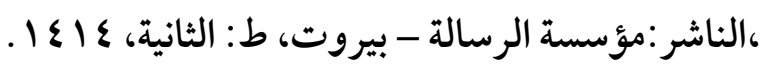

ـ صحيح ابن حزيمة لمحمد بن إسحاق بن خزيمة المكتبة الإسلامية تحقيق د محمد

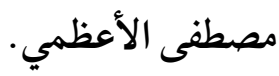
ـ صحيح أبي داود، لمحمد ناصر الدين الألباني، الناشر: مؤسسة غراس للنشر والتوزيع، الكويت.

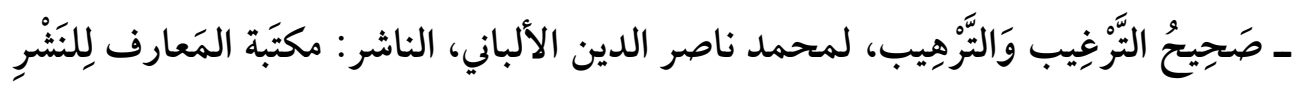

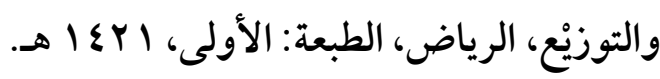

ـ صحيح الجامع الصغير وزياداته، لمحمد ناصر الدين الألباني، الناشر : المكتب الإسلامي. ـ صحيح مسلم، (المسند الصحيح المختصر بنقل العدل عن العدل إلى رسول الله صلى الله عليه وسلم) لمسلم بن الحجاج أبو الحسن القشيري النيسابوري، تحقيق: محمد فؤاد عبد 


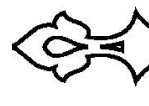

$$
\text { الباقي، الناشر : دار إحياء التراث العربي - بيروت. }
$$

ـ طبقات المحدثين بأصبهان والواردين عليها، لأبي محمد عبد الله ابن حيان الأنصاري المعروف بأبِي الشيخ الأصبهاني، المحقق: عبد الغفور عبد الحق حسين البلوشي، الناشر:

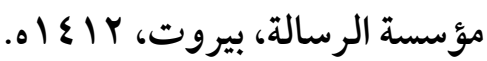
ـ طرح التثريب في شرح التقريب، لأبي الفضل زين الدين عبد الرحيم بن الحسين العراقي، الناشر : دار إحياء التراث العربي.

ـ فتح الباري شرح صحيح البخاري، لزين الدين عبد الرحمن بن أحمد بن رجب الحنبلي، تحقيق: مجموعة من المحققين، الناشر: مكتبة الغرباء الأثرية - المدينة النبوية، الطبعة:

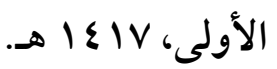
ـ فتح الباري لابن حجر العسقلاني المطبعة السلفية ترقيم محمد فواد عبد الباقي. ـ كثف المشكل من حديث الصحيحين، لأبي الفرج عبد الرحمن ابن الجوزي، المحقق: علي حسين البواب، الناشر: دار الوطن - الرياض. ــالوامع الأنوار البهية وسو اطع الأسرار الأثرية لشرح الدرة المضية في عقد الفرقة المرضية، (عقيدة السفاريني)، لمحمد بن أحمد السفاريني الحنبلي، الناشر: مؤسسة الخافقين ومكتبتها - دمشق، الطبعة: الثانية ץ • ع ا هـ.

ـ مجمع الزوائد ومنبع الفوائد ، الهيثمي ، المحقق: حسام الدين القدسي ، الناشر: مكتبة

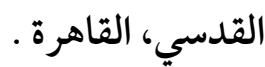
ـ مجموع الفتاوى، لأبي العباس أحمد ابن تيمية، المحقق: عبد الرحمن بن محمد بن قاسم، الناشر : مجمع الملك فهد لطباعة المصحف الشريف، المدينة النبوية، عام: 7 أ اهـ. ـ مجموع فتاوى العلامة عبد العزيز بن باز، لسماحة الشيخ عبد العزيز بن عبد الله بن باز، क⿻ 


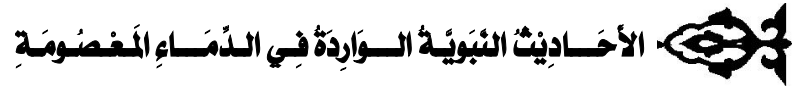 أشرف على جمعه وطبعه: محمد بن سعد الشويعر.}

ـ مجموع فتاوى ورسائل الشيخ محمد بن صالح العثيمين، لمحمد بن صالح العثيمين، جمع وترتيب: فهد بن ناصر السليمان، الناشر : دار الوطن - دار الثريا س إع أهـ.

ـ مختصر سنن أبي داود، للحافظ عبد العظيم بن عبد القوي المنذري، تحقيق: محمد صبحي بن حسن حلاق، الناشر: مكتبة المعارف للنشر والتوزيع، الرياض، الطبعة: الأولى، آبا

ـ مسائل الإمام أحمد بن حنبل وإسحاق بن راهويه، لإسحاق بن منصور المروزي، المعروف

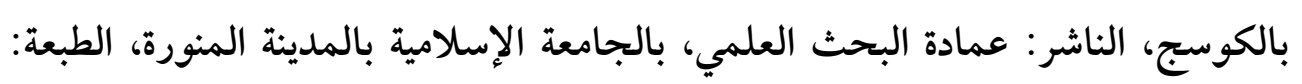

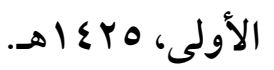
ـ مسند أبي يعلى ، أبو يعلى الموصلي ، المحقق: حسين سليم أسد ، الناشر: دار المأمون

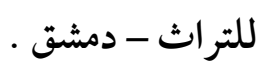
ـ مسند الإمام أحمد بن حنبل، تحقيق: أحمد محمد شاكر، الناشر: دار الحديث - القاهرة،

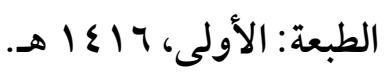

ـ مسند الإمام الشافعي، أبو عبد الله محمد بن إدريس، الناشر : دار الكتب العلمية، بيروت، ، ،

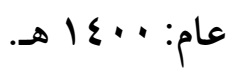
ـ مسند الإمام عبد الله بن المبارك، لعبد الله بن المبارك بن واضح الحنظلي، المحقق: صبحي

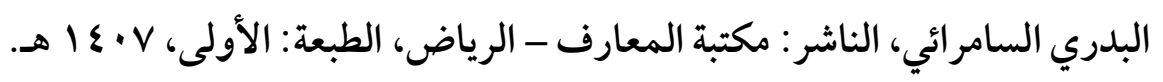
ـ مسند البغوي، لأبي القاسم عبد الله بن محمد البغوي، تحقيق: خلاف محمود عبد السميع،

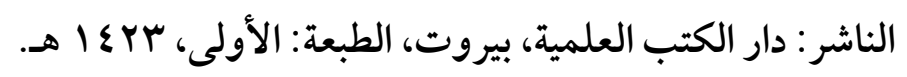

ـ مسند الحميدي لابي بكر الحميدي دار الكتب العلمية ومكتبة المتنبئ تحقيق حبيب

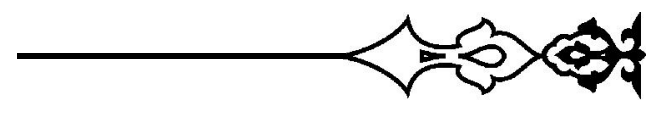


ـ مسند الدارمي المعروف بسنن الدارمي ، أبو محمد الدارمي ، المحقق: نبيل هاشم الغمري ، الناشر : دار البشائر (بيروت) .

ـ مسند الشاميين، لأبي القاسم الطبراني، المحقق: حمدي بن عبدالمجيد السلفي، الناشر:

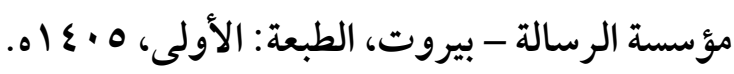
. مسند الطيالسي لأبي داود الطيالسي دار المعرفة بيروت .

ـ مصباح الزجاجة في زوائد ابن ماجه، لثهاب الدين أحمد بن أبي بكر البوصيري، تحقيق:

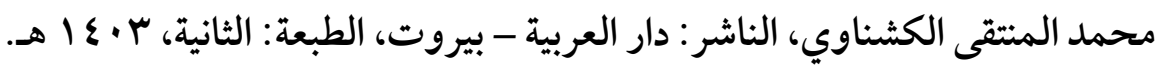

ـ معارج القبول بشرح سلم الوصول إلى علم الأصول، لحافظ بن أحمد بن علي الحكمي،

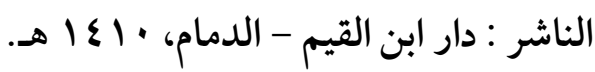

ـ معالم السنن، المؤلف:أبو سليمان الخطابي ، الناشر : المطبعة العلمية - حلب ، الطبعة:

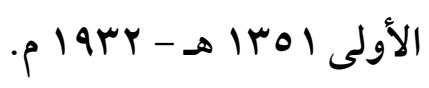

ـ مفتاح دار السعادة ومنشور ولاية العلم والإرادة، لمحمد بن أبي بكر ابن قيم الجوزية، الناشر : دار الكتب العلمية - بيروت.

ـ منهاج السنة النبوية في نقض كلام الشيعة القدرية، لأبي العباس أحمد ابن تيمية، المحقق:

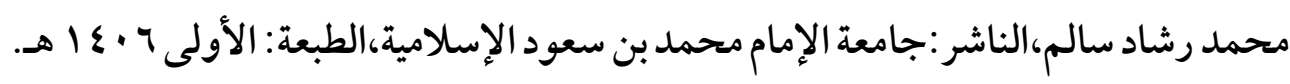
- نزهة النظر في توضيح نخبة الفكر في مصطلح أهل الأثر، لأحمد بن علي بن حجر العسقلاني،

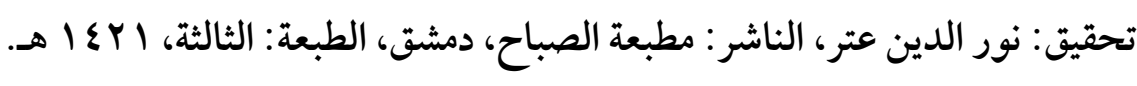
سبحان ربك ربّ العزّة عما يصفون، وسلام على المرسلين والحمد لله ربّ العالمين. 